UNIVERSIDADE DE SÃO PAULO

FACULDADE DE FILOSOFIA, LETRAS E CIÊNCIAS HUMANAS

DEPARTAMENTO DE LETRAS CLÁSSICAS E VERNÁCULAS

PROGRAMA DE PÓS-GRADUAÇÃO EM FILOLOGIA E LÍNGUA PORTUGUESA

Mariana Corallo Mello de Azevedo Kuhlmann

\title{
Os fios de Ariadne: um estudo sobre retratos e valores linguísticos no contexto do refúgio
}

Versão Original

SÃO PAULO

2018 


\title{
Os fios de Ariadne: um estudo sobre retratos e valores linguísticos no contexto do refúgio
}

\author{
Versão Original
}

Mariana Corallo Mello de Azevedo Kuhlmann

Dissertação de Mestrado apresentada ao Programa de PósGraduação em Filologia e Língua Portuguesa do Departamento de Letras Clássicas e Vernáculas da Faculdade de Filosofia, Letras e Ciências Humanas da Universidade de São Paulo, como requisito para fins de obtenção do título de Mestre.

Orientadora:

Prof ${ }^{\mathrm{a}}$. Dr ${ }^{\mathrm{a}}$. Maria Célia Lima-Hernandes

Orientadora: Data:

SÃO PAULO 
Autorizo a reprodução e divulgação total ou parcial deste trabalho, por qualquer meio convencional ou eletrônico, para fins de estudo e pesquisa, desde que citada a fonte.

Catalogação na Publicação Serviço de Biblioteca e Documentação

Faculdade de Filosofia, Letras e Ciências Humanas da Universidade de São Paulo

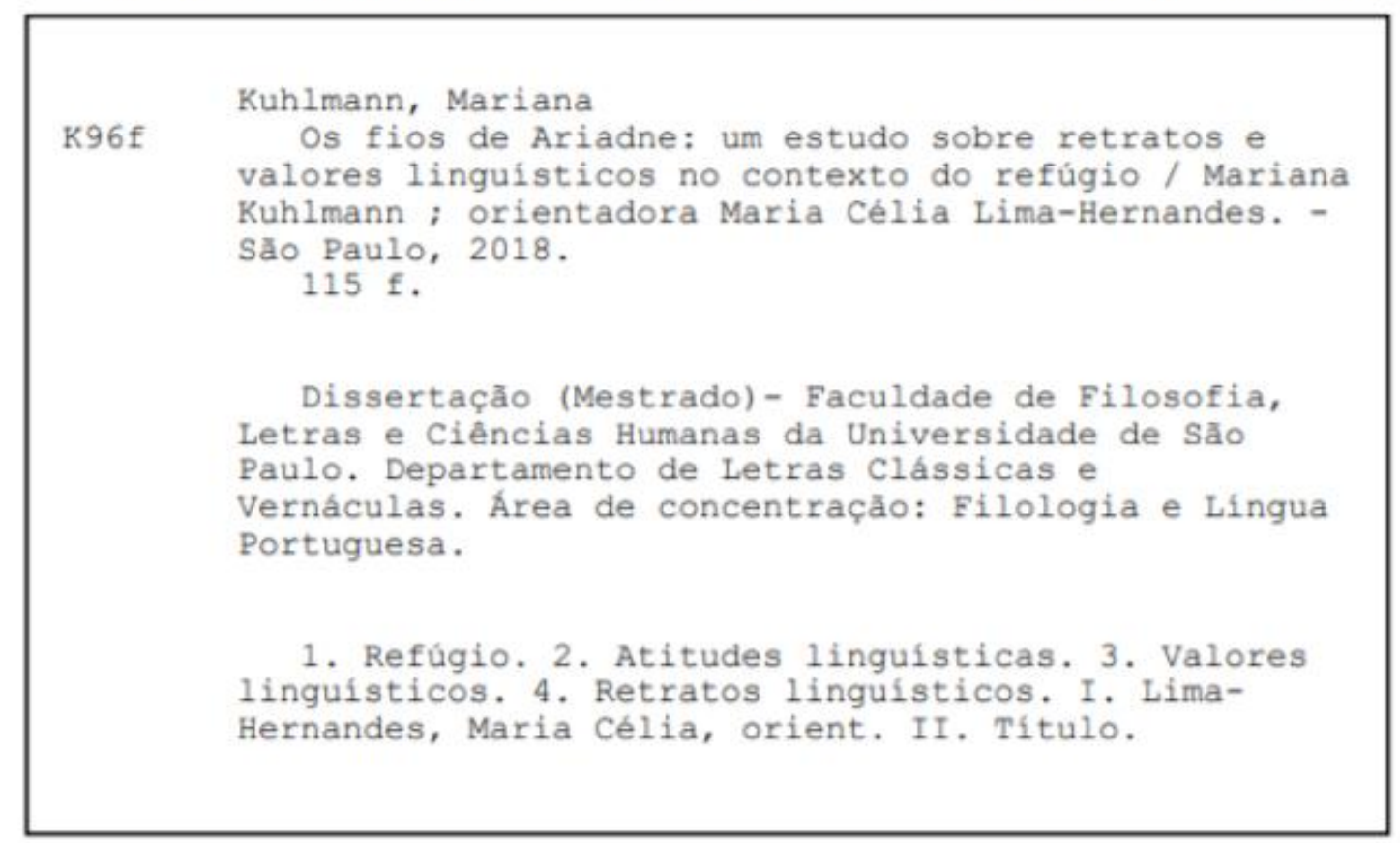




\title{
Banca Examinadora
}

\author{
Membros Titulares
}

Membros Suplentes 
Para Helena e Murilo,

Meus queridos companheiros, sempre presentes nas calmarias e tempestades dessa vida. 


\section{Agradecimentos}

Agradeço a minha querida família, por sempre entender e aceitar o meu jeito de ser e fazer as coisas.

À minha orientadora por me acompanhar e me auxiliar nas empreitadas dessa dissertação.

Aos entrevistados que, por meio dos retratos linguísticos, aceitaram participar desse estudo trazendo cores e perspectivas diferentes para antigos questionamentos. 
Muros altos eram terra plana em nossas pernas correndo.

("Nostempo de miúdo", Boaventura Cardoso 


\section{RESUMO}

A epígrafe escolhida para inaugurar a presente dissertação de mestrado ilustra a experiência de ultrapassar barreiras socioculturais e transpor fronteiras no contexto do refúgio. $\mathrm{O}$ sujeito que se encontra refugiado - é importante enfatizar que o refúgio é uma condição e não um estado inerente ao sujeito - é desafiado a transpor obstáculos que não se limitam apenas a cruzar fronteiras e enfrentar o complexo aparato burocrático que antecede a outorga da solicitação de refúgio. Apenas para citar algumas, as barreiras são linguísticas, culturais, sociais e religiosas. Na busca pela efetiva integração, se faz necessário tornar essas barreiras, terra plana. O título do estudo que se apresenta é inspirado no mito de Ariadne: Teseu, por quem ela era apaixonada, é encarregado de executar o Minotauro, um terrível monstro que habitava um labirinto. Receosa de que Teseu nunca mais retornasse Ariadne lhe presenteia com um fio e com a recomendação de que ele desenrole o carretel enquanto estiver circulando pelo labirinto. Desse modo, Teseu poderia circular pelo labirinto sem se perder. Supomos que a labiríntica experiência do refúgio e da assimilação cultural deixa o sujeito em uma situação de humilhação social. Tal situação pode forçá-lo a se desfazer de sua língua materna, seus fios de Ariadne. Isso não necessariamente ocorrerá, uma vez que a língua materna consiste em uma orientação fundamental do sujeito. Assim, o refúgio desencadeia um processo psicossocial que abala as atitudes linguísticas do sujeito, sendo estas compostas, segundo Lambert e Lambert (1968) por: crenças (componente cognoscitivo), valoração (componente afetivo) e conduta (componente conativo). Para averiguar o impacto causado pela experiência do refúgio nos valores atribuídos às línguas que compõem a realidade linguística do sujeito empregaremos o Princípio da Valoração proposto por Damásio (2011) como principal fundamento teórico. Nossa conduta metodológica empregará os Retratos Linguísticos de Krumm (2003; 2010), um dos chamados "métodos visuais" empregados recentemente nos estudos linguísticos, para enfocar as relações psicoafetivas que o sujeito, na condição de refugiado, estabelece com a sua língua materna e com a língua estrangeira. Consideramos que tanto a discussão quanto a análise propostas consistem em um estudo experimental que se buscará investigar em que medida é possível conciliar métodos visuais e questões linguísticas com vistas a atingir uma maior compreensão sobre a configuração da condição de sujeitos multilíngues que se encontram socialmente vulneráveis.

PALAVRAS-CHAVE: Refúgio. Atitudes Linguísticas. Valores Linguísticos. Retratos Linguísticos. 


\begin{abstract}
The title chosen to inaugurate this master's thesis illustrates the experience of overcoming sociocultural barriers and crossing borders in the context of the refuge. The refugee - it is important to emphasize that the refuge is a condition and not an inherent condition of the subject - is challenged to overcome obstacles that are not limited to crossing borders and facing the complex bureaucratic apparatus that precedes the granting of the request refuge. Just to name a few, the barriers are linguistic, cultural, social and religious. In the search for effective integration, it becomes necessary to make these barriers, flat land. The title of the study that is presented is inspired by the myth of Ariadne: Theseus, for whom she was in love, is in charge to execute the Minotaur, a terrible monster that inhabited a labyrinth. Afraid that Theseus would never return Ariadne gave him a thread with the recommendation that he unwind the reel while he was circling the labyrinth. In this way, Theseus could circulate through the labyrinth without getting lost. We assume that the labyrinthine experience of refuge and cultural assimilation leaves the subject in a situation of social humiliation. Such a situation may force him to discard his mother tongue, his Ariadne threads. This will not necessarily occur, since the mother tongue consists of a fundamental orientation of the subject. Thus, the refuge triggers a psychosocial process that shakes the subject's linguistic attitudes, and these are composed, according to Lambert and Lambert (1968) by: beliefs (cognitive component), valuation (affective component) and conduct (conative component). In order to ascertain the impact of the experience of refuge on the values assigned to the languages that make up the linguistic reality of the subject, we will use the Principle of Valuation proposed by Damásio (2011) as the main theoretical foundation. Our methodological approach will use the Krumm Language Portraits (2003; 2010), one of the so-called "visual methods" recently employed in linguistic studies, to focus on the psycho-affective relationships that the subject establishes with his mother tongue and with the foreign language. We consider that both the discussion and the analysis proposed are an experimental study that will seek to investigate the extent to which it is possible to reconcile visual methods and linguistic issues in order to reach a greater understanding of the configuration of the condition of multilingual subjects who are socially vulnerable.
\end{abstract}

KEY WORDS: Refuge. Linguistic attitudes. Linguistic Values. Linguistic Portraits. 


\section{Lista de Imagens}

Imagem 1. Sugestão de silhueta proposta por Krumm (2010) 59

$\begin{array}{ll}\text { Imagem 2. Imagem usada nos retratos linguísticos } & 74\end{array}$

Imagem 3. Retrato linguístico - Maria 78

Imagem 4. Retrato linguístico - Ana $\quad 79$

$\begin{array}{ll}\text { Imagem 5. Retrato linguístico - Antônia } & 81\end{array}$

Imagem 6. Retrato linguístico - Joana $\quad 82$

Imagem 7. Retrato linguístico - Regina 83

Imagem 8. Retrato linguístico - João $\quad 84$

Imagem 9. Retrato linguístico - Pedro 85

\section{Lista de Tabelas}

Tabela 1. Categorias de análise de Coelho (2015) 58

Tabela 2. Depoimentos de Krumm (2003) 62

$\begin{array}{ll}\text { Tabela 3. Retratos linguísticos } & 77\end{array}$ 


\section{Sumário}

$\begin{array}{ll}\text { Introdução } & 12\end{array}$

I - Refúgio: sujeito e experiência $\quad 20$

$\begin{array}{ll}1.1 \text { Refúgio no mundo } & 21\end{array}$

1.2 Refúgio no Brasil 23

1.3 As condições do refúgio 26

1.3.1 Um povo acolhedor e pacífico 29

1.4 Desenraizamento e o contexto do refúgio 32

1.4.1 Desenraizamento e a experiência da infelicidade 34

1.5 Cidadania no contexto do refúgio 36

1.5.1 Angústia e humilhação social 38

II - Identidade e língua: o contexto do refúgio 41

2.1 Às provas da língua estrangeira 43

2.2 Ensino de língua portuguesa no contexto do refúgio 44

2.3 Língua materna e língua estrangeira: um embate, um encontro $\quad 45$

III - Princípio da Valoração 49

3.1 O Princípio da Valoração à luz de questões linguísticas 52

IV - Discussão e encaminhamentos metodológicos 56

4.1 De cor em cor: métodos visuais a serviço da linguística 57

4.2 A proposta de Krumm 59

4.3 Grupo a ser retratado: os colombianos 67

4.3.1 Situação sócio-histórica $\quad 69$

$\begin{array}{ll}\text { 4.3.2 Línguas da Colômbia } & 71\end{array}$

$\begin{array}{ll}\text { 4.4 A busca pelos dados } & 73\end{array}$

$\begin{array}{ll}\text { V - Análise dos dados } & 77\end{array}$

$\begin{array}{ll}\text { 5.1 Maria } & 78\end{array}$

$\begin{array}{ll}5.2 \text { Ana } & 79\end{array}$

5.3 Antônia 80

$\begin{array}{ll}5.4 \text { Joana } & 81\end{array}$

5.5 Regina $\quad 82$ 
5.6 João

5.7 Pedro 85

VI - (Des)atar nós: reflexões e inquietações 87

Conclusão

92

Anexos

95

Referências bibliográficas 


\section{Introdução}

O mito de Ariadne é assim descrito por Bulfinch (2002): Ariadne, filha do rei Minos de Creta, era apaixonada por Teseu. Seu amado foi encarregado de executar o terrível monstro Minotauro que se escondia em um labirinto e ameaçava à sobrevivência de todos que residiam naquela cidade. Receosa de que Teseu pudesse se perder no labirinto, Ariadne presenteia seu amado com um novelo de lã - o fio de Ariadne. A recomendação da princesa é a de que Teseu, enquanto circula pelo labirinto, desenrole o carretel do novelo de modo a demarcar o caminho de volta. Assim, esse fio serviria de referência e orientação em meio a uma situação angustiante e enigmática. O desfecho da história é conhecido: Teseu consegue executar o monstro e graças ao fio de Ariadne sai ileso do labirinto.

O fio de Ariadne nos conduz a refletir sobre quais são as referências que nos orientam e nos trazem segurança em situações em que nos encontramos social e culturalmente vulneráveis. Por sua vez, a pertinência dessas reflexões é projetável em diferentes contextos em que a sobrevivência e o recurso às origens são problematizados. Para essa ocasião, optaremos por abordar o contexto do refúgio.

Com vistas a analisar a relação entre o sujeito, a sua língua materna e a língua estrangeira, supomos que a língua materna, ou ainda as línguas maternas, e as referências culturais a elas vinculadas constituem um fio de Ariadne que orienta o sujeito e lhe assegura um sentimento de pertença a uma comunidade.

As considerações de Berry $(1997 ; 2005)$ tecidas sobre a indissociabilidade que há entre língua e cultura nos amparam nessa suposição. Para o autor, língua e cultura definem a identidade do sujeito e, por essa razão, influenciam as suas perspectivas em relação ao mundo e o modo como ele reagirá em situações críticas.

No contexto do refúgio, o sujeito na condição de estrangeiro, é subjugado pela sociedade que atendeu a sua solicitação de refúgio. E muito comumente, a suposta sociedade de acolhimento é impiedosa em relação ao fio de Ariadne: o sujeito deve ser assimilado e aprender a falar e se portar como "um de nós".

Essa ilusão da assimilação cultural contribui para o processo de desenraizamento do sujeito, de modo que ele passa a sustentar a crença de que, para garantir a sua sobrevivência nesse novo país, é preciso abandonar algo que não é abandonável, como a língua materna ou ainda, a língua de herança. 
Assim, o contexto de refúgio circunscreve não apenas uma dimensão geopolítica, mas também, uma dimensão linguístico-cultural e psicossocial. Transpor fronteiras, na realidade, nos conduz a transpor e reconfigurar valores atribuídos a línguas, costumes e crenças.

Atualmente, observa-se o seguinte contrassenso que envolve os deslocamentos humanos, não importa em qual modalidade: se, por um lado, o processo de movimentação de bens e mercadorias e a circulação de informações são progressivamente facilitados, por outro, o deslocamento de pessoas tem sido dificultado por políticas restritivas que enfocam a diversidade cultural como um problema que abala a ordem pública e a seguridade nacional.

Em relatório recente, a Agência das Nações Unidas para Refugiados (2017) constatou que os sistemas de proteção internacional estão sob intensa pressão e que o policiamento nas fronteiras está cada vez mais rigoroso. As chamadas "questões de segurança interna" são usadas como pretexto para impedir a entrada de migrantes.

Pita (2016: 5) ampara tais constatações e explana:

A problemática dos refugiados requer uma análise adaptada a um mundo em constante mudança. Deve ser analisada no contexto de um mundo globalizado, o que, como já manifestou o então Alto Comissário António Guterres, tem duas fases: por um lado, os bens e o capital circulam pelo mundo todo com grande facilidade, por outro, a circulação de pessoas se torna cada vez mais restritiva, em particular, a dos segmentos mais vulneráveis, incluindo os refugiados e solicitantes de asilo.

O movimento de partida e chegada gera um caleidoscópio de questionamentos que demandam explicações de diferentes propostas de estudos, estejam elas fundamentadas no direito, na sociologia, na antropologia, nas ciências políticas ou nos estudos sobre língua. Assim como as imagens de um caleidoscópio, qualquer alteração de perspectiva provoca uma reconfiguração dos cristais de modo a modificar o cenário a ser analisado. Assim, esse amplo horizonte teórico-metodológico demanda cautela e sensibilidade perante o recorte temático a ser abordado.

De acordo com Freitas (2008: 21), em meio aos diversos recortes temáticos que tratam dos deslocamentos humanos, ainda há carência de estudos que tenham como escopo a relação entre o sujeito e a sua língua. Por isso, é importante que haja mais estudos dedicados a assumir uma perspectiva linguística sobre os fenômenos dos deslocamentos humanos:

Questões sobre migração têm sido tradicionalmente focadas a partir de áreas como sociologia, a geografia, a antropologia entre outras. Uma proposta de análise do fenômeno sob a lupa da Linguística pode parecer desconexa mesmo para alguns estudiosos da área, acostumados com uma perspectiva analítica que dá primazia para descrições formais de 
propriedades da língua como sistema, conforme tem sido a ênfase da disciplina desde o seu florescer como ciência moderna.

A língua materna do sujeito, em meio a uma situação de vulnerabilidade social, como é a que se enquadra o refúgio, é um fio de Ariadne que o auxilia a enfrentar as paragens angustiantes que compõem uma experiência de humilhação social (GONÇALVES, 1994). No entanto, a sociedade que concede o refúgio pode forçá-lo a atribuir valores negativos à língua materna em favor da língua oficial do país que o acolheu de modo que o sujeito se vê obrigado a cortar esse fio. A partir dessas reflexões, um questionamento torna-se inadiável: seria realmente possível cortar relações com a língua materna?

As relações do sujeito com a suas línguas nos conduzem até o âmbito das atitudes linguísticas. O termo atitude foi inicialmente proposto pela Psicologia Social:

Atitude é uma maneira organizada e coerente de pensar, sentir e reagir em relação a pessoas, grupos, questões sociais ou, mais genericamente, a qualquer acontecimento ocorrido em nosso meio circundante. Seus componentes essenciais são os pensamentos e as crenças, os sentimentos (ou emoções) e as tendências para agir. (LAMBERT e LAMBERT, 1968: 78)

Posteriormente, Lambert e Lambert (1968) enfocam as questões sociolinguísticas à luz do que é considerado atitudes pela Psicologia Social. Para os autores, o sujeito assume uma atitude que pode ser ou prestigiosa ou depreciadora frente à língua e à comunidade a qual essa língua está vinculada. De acordo com essa proposta, as atitudes linguísticas são reações avaliativas que são compostas por crenças (componente cognoscitivo), valoração (componente afetivo) e conduta (componente conativo).

No que concerne especialmente à valoração, as atitudes linguísticas, podem ser entendidas como condutas que são compartilhadas e que podem expressar valores de aceitação ou de rejeição a uma língua.

Labov (2008: 76), ao revisitar as contribuições de Lambert e Lambert (1968; 1972), assim descreve como se dá o compartilhamento de atitudes linguísticas.

O princípio essencial que emerge do trabalho de Lambert é o de que existe um conjunto uniforme de atitudes frente à linguagem que são compartilhadas por quase todos os membros da comunidade de fala, seja no uso de uma forma estigmatizada ou prestigiada da língua em questão. Essas atitudes não emergem de forma sistemática se a pessoa for questionada diretamente sobre os dialetos; mas se ela fizer dois conjuntos de julgamentos de personalidade sobre o mesmo falante usando duas formas diferentes de língua, e se não perceber que é o mesmo falante, suas avaliações subjetivas da língua emergirão como diferenças nas duas pontuações. 
A princípio, discutir valores pode parecer uma tarefa atrelada apenas a questões financeiras, rotineiras e práticas. No entanto, conforme os autores supracitados argumentam, o conceito de valor possui diversas acepções que não ficam restritas às finanças e suscitam uma série de questionamentos sobre como o sujeito reage à pressão social do meio em que ele se encontra:

Consideremos algumas outras questões: porque atribuímos um valor a praticamente tudo o que nos cerca - comidas, casas, ouro, joias, pinturas, ações, serviços e até outras pessoas? Por que todo mundo passa tanto tempo calculando ganhos e perdas em relação a essas coisas? Por que as coisas trazem uma etiqueta de preço? Por que essa incessante valoração? E quais são os padrões para medir o valor? (DAMÁSIO, 2011: 66)

No presente estudo, valores serão considerados como atribuições que o sujeito dá a referências sociais, culturais e linguísticas. E tais atribuições, que podem depreciar ou prestigiar uma língua, ficam subordinadas à necessidade do sujeito em defender o seu espaço social e ser aceito na comunidade em que reside. Damásio (2011) entende por necessidade o impulso do sujeito de sobreviver e manter o seu bem-estar; é justamente esse impulso que faz com que ele valore aquilo que poderá garantir a sua sobrevivência.

Em suma, o sujeito do refúgio pode se sentir impelido a desvalorar a sua língua materna e a valorar a língua estrangeira do país que o acolheu com o intuito de ser integrado e escapar do Minotauro da marginalização social. Por outro, a língua materna pode lhe assegurar um confortador senso de comunidade e pertença ao seu país de origem. Cortar com esse fio de Ariadne pode provocar reverberações problemáticas na subjetividade do sujeito.

Esse conflito entre os valores impregnados em certas atitudes linguísticas coloca o sujeito que se encontra vulnerável em uma verdadeira encruzilhada linguística e cultural. Assim, segundo Lambert e Lambert (1968: 85) com a finalidade de "melhorarem as suas posições e incentivarem seu senso de valia, os membros de grupos minoritários identificam-se, aparentemente, e incorporam, insensatamente, as atitudes estereotipadas" dos que detêm o poder.

O que nos parece relevante é buscar meios que possibilitem a apreensão desse conflito de modo a evidenciar particularidades do refúgio enquanto uma experiência que é protagonizada por um sujeito que luta por sua sobrevivência em busca da integração e que pode, mas não necessariamente, abdicar de sua língua materna em favor da língua oficial do país que o acolheu. 
Damásio (2011) ainda tece uma série de considerações sobre a sobrevivência entendida não apenas como um fenômeno biológico, mas também sócio-cultural. A depender do contexto, o sujeito é forçado a valorizar os recursos que, aparentemente, poderão garantir o seu bem-estar. No caso do refúgio, a sociedade de acolhimento pode assumir um discurso de dominação e induzir o sujeito a desvalorar as suas heranças linguístico-culturais; por outro, parece que essas heranças, por constituírem a sua identidade, não podem ser simplesmente descartadas e, na realidade, amparam o sujeito enquanto ele se encontra socialmente vulnerável. Cabe indagar que tipo de método ou conduta de estudo é capaz de abordar esse embate entre os valores declarados e os valores internalizados.

O uso de métodos visuais (desenhos e atividades de colorir) que têm sido empregados para investigar a relação afetiva e psicossocial do sujeito com as suas línguas é uma conduta metodológica recente nos estudos linguísticos, mas que já é conhecida e usada em outros campos de estudo como a psicologia analítica.

Jung (2002), por exemplo, empregava o método das mandalas quando tratava seus pacientes. Para isso, ele apresentava uma figura circular - a mandala - e solicitava que o sujeito a colorisse com lápis de cor ou giz de cera de modo a representar a si mesmo. O autor acreditava que essa tarefa de reflexão auxiliava o paciente a extravasar por meio de representações simbólicas entre formas e cores os conflitos que estavam internalizados em sua subjetividade. Após essa tarefa, o sujeito poderia explicar por meio do discurso os impulsos que o levaram a se auto-retratar desse modo.

Colorir as mandalas consiste então, para a psicologia analítica, em uma atividade motora que ativa tanto as funções cogntivas quanto às funções psicoafetivas do sujeito permitindo com que ele organize eventuais experiências traumáticas. A partir dessa atividade, ainda é possível expressar concretamente o que está imerso numa dimensão abstrata da subjetividade, como os afetos e as lembranças.

Por essa razão, o que propomos para essa ocasião é um estudo que pode ser considerado experimental, uma vez que a conduta metodológica que será assumida se baseará em um dos métodos visuais disponíveis empregados nos estudos linguísticos.

Com vistas a abordar o contexto linguístico da experiência do refúgio, assumiremos que as dificuldades de integração e acesso à cidadania sofridas pelo sujeito que se encontra na condição de refugiado consistem numa perturbação que o ameaça e o angustia. Diante dessa situação, o sujeito se vê obrigado agir de modo que a sua 
sobrevivência e o seu bem-estar na sociedade de acolhimento sejam assegurados. Para isso, os valores atribuídos às suas origens e referências culturais podem sofrer golpes que podem conduzi-lo a desvalorar a(s) sua(s) própria(s) língua(s) materna(s).

Vários autores propõem diferentes métodos visuais para analisar a relação do sujeito e as línguas materna, de herança e estrangeira. Krumm $(2003 ; 2010)$ nos fornece um interessante aparato teórico-metodológico para atingir tal propósito. Trata-se dos retratos linguísticos. Ao assumir uma conduta metodológica que se enquadra nos "métodos visuais" o autor sugere que para acessar os valores a respeito de uma língua e, assim, contrastá-los com os valores que são declarados perante o outro com o intuito de alcançar aceitação, é preciso que o sujeito expresse tais valores por meio da tarefa de colorir a silhueta (o contorno) de um corpo com o objetivo de representar o seu universo linguístico. Essa tarefa é orientada de modo que o sujeito seja confrontado com o seguinte questionamento: que línguas falo, que línguas eu conheço e qual a importância/valor que essas línguas têm para mim?

Para Krumm $(2003 ; 2010)$ a associação entre as cores e a forma como o sujeito distribui as línguas que compõem o seu universo linguístico pelo seu corpo representado no papel revela os valores que permanecem encobertos no discurso. Semelhante à posição de Jung (2002), os retratos linguísticos propostos por Krumm (2003; 2010) visam expressar em uma dimensão concreta as relações simbólicas abstratas que o sujeito estabelece com a sua realidade linguística. Certamente, conforme veremos adiante, os desenhos por si só não consistem em uma fonte de informações confiável.

É preciso que o sujeito descreva por meio de um depoimento aquilo que ele representou para que ele realmente faça um exercício de reflexão linguística. Na proposta krummiana, a reflexão linguística é um exercício em que o sujeito expressa e compartilha as atribuições, positivas e negativas, que ele dá a certas línguas. Aparentemente, um dos maiores benefícios proporcionados pelos retratos linguísticos na busca por dados é que o sujeito, enquanto realiza a tarefa proposta, pode se sentir desinibido ao retratar a sua percepção em relação a sua realidade linguística. Assim, há maiores chances de evitar que os valores linguísticos dos grupos dominantes interfiram nos dados obtidos.

Na ocasião em que procedemos à coleta dos dados, se fez necessária a tradução do alemão para o português e, posteriormente, a análise de um dos estudos de Krumm (2003). Após essa tarefa, a proposta dos retratos linguísticos foi empregada com vistas a 
investigar o universo linguístico de um sujeito multilíngue que se encontra refugiado na cidade de São Paulo. Para manter o rigor de análise e considerando o mosaico de nacionalidades que compõem a população refugiada no Brasil, optamos por estudar os retratos linguísticos fornecidos por sujeitos de nacionalidade colombiana.

Alguns questionamentos servirão de respaldo para que possamos alinhavar o escopo do presente estudo:

(1) Os métodos visuais, sobretudo a proposta de Krumm (2003; 2010), consistem em procedimentos metodológicos eficientes na busca de informações referentes aos valores atribuídos às línguas que são faladas por um sujeito multilíngue?

(2) A proposta de Krumm (2003; 2010) pode ser empregada com a finalidade de abordar situações de humilhação social à luz de questões linguísticas?

(3) Os retratos linguísticos são um método viável para acessar atitudes linguísticas de adultos no contexto do refúgio?

Os objetivos que nos orientarão na empreitada de responder a tais questões são os seguintes:

(1) Empregar o método de Krumm $(2003 ; 2010)$ para evidenciar atitudes linguísticas que levam o sujeito a desvalorar a sua língua e as suas referências culturais;

(2) Verificar em que medida tais atitudes são consequências de uma situação de humilhação social;

(3) Verificar em que medida a língua materna do sujeito persiste como um fio condutor que ata um sentimento de pertença a uma comunidade que não se faz presente concretamente, mas permanece na identidade do sujeito; (4)Verificar se realmente há uma disparidade entre os valores linguísticos que são declarados e os que constituem a identidade do sujeito.

(5) Verificar em que medida o Princípio da Valoração pode ser empregado quando desentrincheiramos os valores atribuídos a uma língua.

Para lidar com essas hipóteses e objetivos pressupostos, organizamos esta dissertação em seis capítulos. No capítulo 1 nos dedicaremos a discutir o refúgio 
enquanto uma experiência de humilhação psicossocial que atinge o sujeito de modo a torná-lo vulnerável e a desencadear processos de desenraizamento.

No capítulo 2 abordaremos a dinâmica entre identidade e língua no contexto do refúgio. Orientaremos a discussão proposta com vistas a abordar o impacto que o sujeito sofre quando aprende uma língua estrangeira, sobretudo em circunstâncias críticas. Após tratar das tensões estabelecidas entre língua materna e língua estrangeira, passaremos ao capítulo 3 para discutir o Princípio da Valoração proposto por Damásio (2011) à luz de questões linguísticas.

Os encaminhamentos metodológicos tomarão espaço de discussão no capítulo 4, quando enfocaremos os métodos visuais, em específico os retratos linguísticos de Krumm (2003; 2010). Essa também será a ocasião de tecer considerações sobre o grupo que participou da pesquisa: os colombianos.

No capítulo 5 apresentaremos os dados obtidos em nosso trabalho de campo para então discorrer no capítulo 6 sobre as reflexões e inquietações teórico-metodológicas referentes aos retratos linguísticos. Por fim, daremos encaminhamento para a conclusão do estudo proposto. O texto traduzido de Krumm (2003) que amparou grande parte das hipóteses apresentadas se encontra nos Anexos. 


\section{I - O refúgio: sujeito e experiência}

Abordar o tema do refúgio requer uma conduta de estudo que não seja afeita a rótulos, por mais que pareça inevitável postular respostas estanques a questões como “quem é o sujeito do refúgio?” ou ainda "o que é o refúgio?”. Considerando que esse assunto consiste em lançar um olhar dinâmico a um mundo que se reconfigura constantemente, é mais apropriado apresentar uma proposta de estudo que reconhece essa movimentação que abala cada vez mais as estruturas e os rótulos que nos são aparentemente rígidos e inquestionáveis.

O refúgio, apesar de aparentemente ser um tema atual, na realidade se trata de uma modalidade de deslocamento humano cujo fundamento definidor remonta à Antiguidade. Menezes (2011: 35) ressalta essa particularidade do refúgio. Segundo a autora, registros históricos indicam que o conceito de acolhimento de contingentes populacionais em situação de crise existe desde a Antiguidade.

Pesquisas históricas revelam a existência do costume de se prover proteção a estrangeiros desde a Antiguidade, sob a forma de asilo. $\mathrm{O}$ asilo era entendido e aplicado na Antiguidade e na Idade Média a partir de um fundamento religioso - o que possibilitava, inclusive, que criminosos comuns gozassem de seus benefícios. Esse instituto se desenvolveu no período moderno até chegar a sua configuração atual, marcada por um caráter político.

A princípio, é importante compreender que o refúgio é uma forma de mobilidade populacional que provoca uma série de alterações impactantes no espaço social e no sujeito, devido ao contexto crítico em que ele sucede. Isso ocorre porque ele envolve elementos tanto da ordem do espaço social quanto elementos de ordem subjetiva. Tais elementos, indubitavelmente, interagem entre si de forma a estabelecer uma dinâmica que é marcada, em essência, por tensões.

$\mathrm{Na}$ ordem do espaço social, há de um lado um país que precisa se estruturar para promover a integração social desses grupos refugiados, de modo a amenizar a marginalização e o preconceito sofridos por eles. De outro lado, há um país, o país de origem, que precisa enfrentar as causas do deslocamento populacional - como conflitos internos e desastres naturais - e as consequências dele - como o eventual desequilíbrio demográfico decorrente das numerosas solicitações de refúgio.

Já, na ordem subjetiva, verifica-se uma interação social em que o sujeito que se encontra nessa condição e o sujeito que não se encontra nessa condição passam a ocupar um mesmo espaço. Nessas circunstâncias, diferenças culturais e conflitos emergem e 
elas atuarão decisivamente nos processos de integração social e reconstituição identitária a serem enfrentados por esse sujeito.

\subsection{O Refúgio no Mundo}

Segundo a Agência da Organização das Nações Unidas para Refugiados (ACNUR) em 2017, 1 em cada 113 pessoas no planeta é solicitante de refúgio, deslocada interna ou refugiada. A organização também constatou que nas últimas décadas mais de 67 milhões de pessoas deixaram seus países de origem em razão de conflitos, perseguições e graves violações aos direitos humanos. Desse total, 22 milhões foram reconhecidas como refugiadas e acolhidas, em sua maioria, por países cujo desenvolvimento econômico ainda é incipiente.

A maior parte daqueles que se encontram refugiados tiveram suas solicitações de refúgio atendidas por países do continente africano. Ou seja, os países desenvolvidos por mais que, teoricamente, apresentem mais respaldo econômico para acolher essa população, apresentam também uma conduta de concessão de refúgio mais restritiva. Esses dados comprovam que nos deparamos com uma crise geopolítica envolvendo a questão do refúgio (ARAÚJO, 2003). Para compreender o impacto desse fato, é de suma importância considerar inicialmente a conjuntura político-histórica característica do período em que a condição do refúgio foi institucionalizada. Esse período abarca tanto a Primeira quanto a Segunda Guerra Mundial, assim como o período posterior a elas.

Sprandel e Milesi (2003: 115), ao descreverem a consolidação histórica do refúgio em nível internacional, apontam que a formalização do acolhimento de refugiado teve início nos anos 1920 com a nomeação, regulamentada pela Liga das Nações, de um Alto Comissário para Refugiados. A crescente perseguição dos grupos minoritários e opositores ao regime nazista provocou a elaboração da Convenção de Genebra em 1933.

Com o agravamento da violação aos direitos humanos que caracterizou o fortalecimento e a expansão dos regimes totalitários foi criado em 1938 o Comitê Intergovernamental para Refugiados (OIR). O principal objetivo do OIR naquela ocasião, consistiu em otimizar temporariamente o encargo de acompanhar as vítimas desse momento histórico, 
Mesmo após o desfecho da Segunda Guerra Mundial, a questão dos refugiados enquanto um problema de ordem emergencial persistiu, de modo que um órgão de caráter temporário, como era o OIR, não estava apto a exercer a função de atender a todos os grupos que a ele recorriam. Por essa razão, fez-se necessária a instituição de um órgão permanente. Assim, é fundada a Agência das Nações Unidas para Refugiados (ACNUR) em 1950, juntamente com uma regulamentação mais específica referente ao estatuto do sujeito que se encontra refugiado.

No final de 1950, a Assembleia Geral das Nações aprovou, pela Resolução 428, o Estatuto do Escritório do Alto Comissariado das Nações Unidas para Refugiados (ACNUR), que previu também a elaboração de uma Convenção Internacional sobre a proteção dos refugiados, aprovada no ano seguinte, em 28 de julho de 1951, como Convenção sobre o Estatuto dos Refugiados e modificada pelo Protocolo sobre o Estatuto do Refugiado de 1967. (SPRANDEL e MILESE, 2003: 116)

A Convenção sobre o Estatuto dos Refugiados (1967) assume a condição de refugiado como sendo aquela em que o sujeito se encontra quando devido a fundados temores de perseguição por motivos de raça, nacionalidade, grupo social ou opiniões políticas, se encontra fora de seu país de origem. Aplica-se igualmente ao que não quer valer-se da proteção de seu país de origem em decorrência desses fundados temores de perseguição:

Um refugiado é uma pessoa que está fora do seu país natal devido a fundados temores de perseguição relacionados a raça, religião, nacionalidade, grupo social ou opinião política. São pessoas comuns, que tiveram que deixar para trás seus bens, empregos, familiares e amigos para preservar sua liberdade, sua segurança e sua vida. Também são consideradas refugiadas pessoas obrigadas a deixar seus países devido a conflitos armados, violência generalizada e violação massiva dos direitos humanos. (ACNUR, 2014: 4)

A repercussão das violações cometidas contra a dignidade do sujeito e a busca empreendida por ele no restabelecimento e reconhecimento da sua dignidade frente a conflitos militares e à supressão dos seus direitos básicos, impactam de tal forma a comunidade internacional que as nações foram forçadas a se posicionar em função do acolhimento dos refugiados.

Marcolini (2003) afirma que a situação dos refugiados no século XXI é problemática e complexa. Um dos primeiros fatores agravantes discutidos pela autora se refere à redução, que se verificou nos últimos anos, da verba atribuída à ACNUR. Como as funções exercidas por esse órgão dependem de contribuições voluntárias dos países integrantes das Nações Unidas, o seu orçamento fica sujeito a flutuações e mais sensível ainda às crises e instabilidades econômicas: 
Uma das facetas tristes do cenário descrito é a redução da verba destinada ao ACNUR pelos países membros das Nações Unidas. Ao contrário da secretaria-geral da ONU, cuja verba vem de contribuições obrigatórias a que estão sujeitos os países associados à Nações Unidas, o dinheiro das agências da ONU depende da contribuição voluntária dos países. (MARCOLINI, 2003: 205)

Como consequência disso, a redução orçamentária lamentavelmente reduz também a atuação da ACNUR e de todas as instituições direta ou indiretamente a ela vinculadas. Logo, todas as ações dedicadas a promover a inclusão social da população refugiada compulsoriamente entram em crise e sofrem de modo gradativo uma série de restrições. Isso indica um contrassenso, coforme Marcolini (2003) argumenta: enquanto há um exponencial aumento do número de pessoas sob a responsabilidade da ACNUR. há simultaneamente, uma progressiva diminuição da autonomia e dos recursos da agência.

É preciso reconhecer que as considerações tecidas até então são de fato essencialmente de cunho histórico. No entanto, tais considerações servem inegavelmente como alicerce na elaboração de uma compreensão contemporânea que recai na realidade e na percepção brasileiras sobre o tema, assim como todas as implicações socioculturais que incorrem na sociedade.

\subsection{O Refúgio no Brasil}

A instalação oficial do escritório da ACNUR no Brasil ocorreu em 1970 juntamente com a adesão à Convenção de Genebra. Apesar da postura aparentemente receptiva assumida pelo País em relação à questão dos refugiados, é preciso salientar que, naquele momento, o país optou pela cláusula de reserva geográfica prevista na Convenção de Genebra. Assim, para que um sujeito tivesse a sua solicitação de refúgio atendida, era necessário que ele apresentasse atributos específicos:

O país optou pela cláusula da reserva geográfica pela qual se comprometia a reconhecer como refugiados somente as pessoas que reunissem os requisitos próprios para configurar a condição de refugiadas em consequência de "acontecimentos ocorridos antes de $1^{\circ}$ janeiro de 1951 na Europa". (SPRANDEL e MILESI, 2003: 118)

Somente em 1989 a cláusula foi revogada como consequência do recebimento e reconhecimento de refugiados iranianos.

A partir de então, foi recebido um número tão expressivo de refugiados que em 1997 a população de indivíduos nessa condição atingiu a ordem de três mil pessoas. Por essa razão, se fez necessária a elaboração de uma lei que incorporasse os princípios 
gerais das convenções e protocolos internacionais mais modernos da área. Em 22 de julho de 1997 foi sancionada a Lei 9.474 pelo então Presidente Fernando Henrique Cardoso. Sobre a condição de refugiado, a Lei postula:

Art. $1^{\circ}$ Será reconhecido como refugiado todo indivíduo que:

I - devido a fundados temores de perseguição por motivos de raça, religião, nacionalidade, grupo social ou opiniões políticas encontra-se fora de seu país de nacionalidade e não possua ou não queira acolher-se à proteção de tal país;

II - não tendo nacionalidade e estando fora do país onde antes teve sua residência habitual, não possa ou não queira regressar a ele, em função das circunstâncias descritas no inciso anterior;

III - devido a grave e generalizada violação de direitos humanos, é obrigado a deixar seus país de nacionalidade para buscar refúgio em outro país.

Antes da aprovação da Lei 9.474, a postura do governo brasileiro, apesar da adesão à Convenção de Genebra, apresentava tendências conservadoras e visava à securidade nacional. Tais condições pressupunham que havia o reconhecimento da presença do sujeito na condição de refugiado, mas, paralelamente a esse reconhecimento, a abordagem dessa questão era nacionalista. Nesse momento, havia uma forte orientação pautada na preservação de uma pretensa identidade brasileira e não se considerava a necessidade de integrar os refugiados.

Nesse sentido, houve um importante avanço conceitual em relação ao tratamento anterior, ao passar o Brasil a entender o refugiado como todo aquele que, devido a fundados temores de perseguição por motivos de raça, religião, nacionalidade, grupo social ou opiniões políticas, recorra à proteção brasileira. Preocupou-se o legislador brasileiro com a grave e generalizada violação dos direitos humanos e mostrou-se aberto, seguindo a tendência internacional na matéria, à possibilidade do acolhimento em solo nacional de grupos de refugiados e não apenas de casos individuais. (VERWEY, ZERBINI e SILVA, 2000: 184)

A recepção das demandas e a análise das solicitações de refúgio encaminhadas ao Brasil são analisadas pelo Comitê Nacional para Refugiados (CONARE), órgão criado na ocasião da sanção da Lei 9.474/97. Sob a responsabilidade do CONARE fica também a análise das demandas de refúgio e a formulação de políticas para refugiados vivendo no País. O comitê também organiza reuniões entre as agências governamentais, organizações da sociedade civil e a própria ACNUR e pode contribuir para as discussões estabelecidas entre as partes envolvidas nessas reuniões sem, no entanto, ter direito a voto.

Até o final de 2016 foram reconhecidos 9.552 refugiados de 82 nacionalidades diferentes; além disso, entre essas 82 nacionalidades diferentes, os países com maior número de refugiados reconhecidos foram, respectivamente, a Síria (326), a República Democrática do Congo (189), o Paquistão (98), a Palestina (57) e a Angola (26). 
Os dados referentes ao ano de 2017 ainda não foram divulgados oficialmente por meio de relatório. No entanto, segundo o Ministério da Justiça e o CONARE ${ }^{1}$, estima-se que houve um aumento em $228 \%$ das solicitações de refúgio para o Brasil, contabilizando um total de 33.865 pedidos. A maioria das solicitações processadas em 2017, um total de 17.865 pedidos, partiu de venezuelanos. Em seguida, os quatro países de origem com maior número de solicitantes de refúgio são Cuba (2.373), Haiti (2.362), Angola (2.036) e China (1.462).

Esses dados nos conduzem a refletir sobre a dimensão humana das estatísticas do refúgio. Por detrás dos 33.865 pedidos de refúgio há também 33.865 relatos que por razões diversas foram marcados pelo crivo da vulnerabilidade social que caracteriza as condições do refúgio.

Atualmente, o Brasil é considerado pela comunidade internacional um país acolhedor quando o tema em pauta é o refúgio e pioneiro nas Américas no que concerne à integração de refugiado.

Apesar do pioneirismo brasileiro e da receptividade (MOREIRA, 2015), é preciso admitir que melhorias devam ser feitas tanto no acolhimento, quanto na integração dos refugiados à sociedade. É importante ressaltar também que as barreiras à integração da população refugiada não são apenas referentes à falta de infraestrutura do país de acolhimento. A discriminação e a falta de conscientização das pessoas em relação à condição do refúgio contribuem para o isolamento e consequentemente marginalização daqueles que se encontram nessa condição.

Carecemos, e muito, no Brasil de sensibilização e conhecimento sobre a realidade do refúgio, assim como de maior preocupação e atuação do governo na realização de convênios nas áreas de saúde, educação, emprego para garantir melhores condições de vida para os refugiados. (SPRANDEL e MILESI, 2003: 128)

Em consonância com essa afirmação, há o posicionamento de Moreira e Baeneinger (2010: 31). As autoras argumentam que a sociedade brasileira oferece resistência ao acolhimento de grupos refugiados, sendo que os obstáculos mais críticos são a falta de moradia, a dificuldade de encontrar emprego e atendimento médico, assim como a discriminação:

\footnotetext{
${ }^{1}$ Os dados fornecidos pelo Ministério da Justiça e o Comitê Nacional para Refugiados foram divulgados na mídia por meio da Lei de Acesso à Informação em janeiro de 2018. Contudo, conforme o próprio artigo afirma, não há ainda relatório oficial publicado por esses órgãos. Disponível em: https://g1.globo.com/mundo/noticia/brasil-registra-numero-recorde-de-solicitacoes-de-refugio-em2017.ghtml. Acesso em: 23 de fevereiro de 2018.
} 
Eles encontram dificuldades em ter acesso a serviços públicos básicos, particularmente cuidados médicos e moradias. Finalmente, eles se sentem discriminados pela população local. A sociedade brasileira não sabe ao certo $o$ que (grifo nosso) é um refugiado e com frequência os reconhece como fugitivos da justiça, tornando a integração na sociedade e no mercado de trabalho ainda mais difícil.

Outra questão que precisa ser mencionada diz respeito à infraestrutura apropriada ao acolhimento da população que se encontra refugiada no Brasil. O CONARE é uma instituição em nível federal, no entanto, a grande maioria das iniciativas dedicadas a assistir a essa população não é amparada pelo governo. Os encargos do acolhimento e da orientação ficam relegados a organizações não governamentais, sustentadas financeiramente por doações e trabalhos voluntários.

Desse modo, o sujeito na condição de refugiado acaba vivenciando uma situação de acolhimento complexa: mesmo os discursos que visam à defesa de seus direitos e à conscientização da sociedade de acolhimento acabam sendo impregnados por uma concepção que ignora a própria humanidade do sujeito do refúgio. Ou seja, ao invés de propor a conscientização da sociedade sobre quem é o sujeito que se encontra refugiado, acaba-se propondo a conscientização sobre o que é um refugiado, conforme consta na citação exposta acima, como se ele fosse objetificado e enquadrado numa categoria de coisas.

Além disso, o sujeito do refúgio precisa se adaptar às particularidades de um contexto social diferente daquele que há em seus países de origem, mas enfrentam barreiras que tornam esse novo contexto social inacessível. Assim, se por um lado o sujeito é oficialmente autorizado a ocupar o espaço do refúgio na sociedade de acolhimento, por outro, a própria sociedade de acolhimento não o enxerga nesse espaço e não cria suficientemente meios para que ele interaja e se posicione na sociedade.

Como a condição do refugiado parece contemplar suas necessidades de desnudar o tendão de Aquiles de sua integração brasileira, dedicamos o próximo capítulo a essa questão. Mais precisamente, trataremos das dificuldades enfrentadas pelos refugiados no contexto brasileiro.

\subsection{As condições do refúgio}

Há uma forte tendência de que discussões centradas no refúgio se pautem em questões de cunho jurídico e institucional. A abordagem dessas questões, apesar de ser de importante relevância para a compreensão do tema, acaba desconsiderando por vezes 
a interferência que as circunstâncias do refúgio exercem no sujeito e no seu cotidiano. Como resultado, obtêm-se um conhecimento raso referente ao fenômeno sócio-histórico do refúgio e sobre a realidade do sujeito que vivencia essa experiência.

Referenda essa posição o estudo de Marinucci e Milesi (2003: 13), que constatam que, de fato, os elementos históricos que perpassam pela questão do refúgio são reconhecidamente discutidos. No entanto, o cotidiano das pessoas que enfrentam essa experiência é pouco abordado:

A questão dos refugiados é tão antiga quanto a humanidade. Desde criança sabemos da existência de guerras, conflitos, imperialismos, colonialismos, perseguições políticas e religiosas que perpassaram a caminhada histórica de todos os povos. Infelizmente, as informações nem sempre se referiam às consequências que tais acontecimentos causaram na vida cotidiana das pessoas.

Ao contrário do que se pode supor a experiência do refúgio não deve ser confundida com a experiência da migração voluntária, embora ambas sejam modalidades de deslocamento humano.

\footnotetext{
Enquanto as pessoas refugiadas estão em uma situação muito vulnerável, pois não têm proteção de seus respectivos países e sofrem ameaças e perseguições, os migrantes internacionais escolheram viver no exterior principalmente por motivações econômicas, podendo voltar com segurança a seu país de origem se assim desejarem. (ACNUR, 2018, p.10)
}

O sujeito da migração voluntária desloca-se, em certa medida, orientado por um planejamento prévio que pode ser mais ou menos pormenorizado, mas que indubitavelmente o auxilia e o ampara no processo de transição de um país a outro. Não há ainda, em princípio, nenhum impedimento jurídico, religioso, militar, cultural ou sociopolítico que torne inviáveis tanto o deslocamento quanto o retorno ao país de origem.

Já o sujeito do refúgio, por sua vez, desloca-se orientado por questões de sobrevivência. Sua fuga não deve ser compreendida em âmbito penal, como se ele tivesse sido o autor de um crime, mas, sim, contextualizada à luz de quaisquer circunstâncias de violação aos seus direitos humanos. A Declaração de Cartagena (1984) destaca a importância de se observarem tais circunstâncias, uma vez que a violência maciça praticada contra os direitos humanos seria crucial para se definir a condição de estar ou não refugiado.

Desse modo, não há, na experiência do refúgio um planejamento prévio; o sujeito fica à mercê das autoridades e dos protocolos de proteção internacionais. Também há, em princípio, uma série de impedimentos para o retorno ao país de origem, 
como ocorre, por exemplo, em caso de guerra civil e demais conflitos armados, bem como requisitos legais que devem ser atendidos para que o seu deslocamento seja viabilizado.

Tanto o refugiado quanto o migrante voluntário enfrentarão certamente questões referentes aos desafios à integração. No entanto, é importante destacar que é o caráter involuntário do refúgio enquanto deslocamento humano que o diferencia da migração voluntária, conforme Borges (2013, p. 152) explana:

Quando nos referimos aqui ao caráter involuntário dessa categoria de migração, salientamos que o refugiado - contrariamente ao migrante voluntário -, além de não ter planejado sua partida, também não planejou sua transição entre o país de origem e o de acolhida e não ter se projetado nesse novo lugar. Essa distinção não deve ser considerada apenas como um detalhe que distingue dois tipos de migração. Nessa distinção também estão implícitas outras diferenças. Dentre elas, deve-se destacar o tipo de trabalho psíquico que o processo de migração involuntária exigirá da pessoa, assim como o impacto desse trabalho sobre a saúde mental do refugiado.

No que concerne aos principais desafios enfrentados pelo sujeito do refúgio, Araújo (2003) lista: (1) o desafio de ser aceito nas relações sociais da sociedade de acolhimento; (2) o desafio de alcançar a cidadania; (3) o desafio de manter suas crenças religiosas e de preservar o seu patrimônio cultural; (4) o desafio de dominar o idioma do país de acolhimento e de se posicionar perante o outro; (5) o desafio de ter acesso ao sistema educacional de modo a garantir boas oportunidades de emprego; (6) o desafio de se sentir em segurança e superar o medo de ser deportado.

Discutir esses desafios à integração nos conduz a refletir sobre a conduta de tolerância que é assumida pela sociedade de acolhimento. Certamente, se esses desafios persistem é porque há possivelmente nas iniciativas de acolhimento uma postura de tolerância que impede que a integração do sujeito do refúgio se realize efetivamente.

Nitidamente, a sociedade brasileira ainda conserva notável resistência ao acolhimento daqueles que se encontram na condição de refugiado. Observa-se a presença de atitudes pautadas na concepção restritiva de mera tolerância e que amparam discursos que podem ser, ou não, aparentemente inofensivos, mas que asseguradamente são discriminatórios e que, na prática, sustentam os desafios à integração.

Lopes (2012: 79) afirma que a tolerância provoca a coexistência entre grupos minoritários e grupos dominantes. Essa dinâmica, segundo a autora, não incentiva o diálogo e a convivência, uma vez que "tolerar não necessariamente significa respeitar: a tolerância pode ser apenas um ato de indiferença, podendo chegar a ser uma espécie de gentil-não respeito". As consequências dessas práticas de tolerância corroboram para 
um projeto de integração do sujeito que se encontra refugiado o qual é, no mínimo, questionável e que apresenta limitações.

No entanto, a tolerância apresenta limitações. A construção de um Estado democrático exige não apenas o reconhecimento e proteção de sua diversidade cultural, mas também a implementação de mecanismos espaciais capazes de garantir às minorias o pleno exercício de seus direitos fundamentais. Depois de tudo, o Estado não deve apenas garantir a coexistência, mas deve também assegurar a convivência entre todos os membros da sociedade. (LOPES, 2012: 79)

\subsubsection{Um povo acolhedor e pacífico}

Recentemente, estudos desenvolvidos pela Anistia Internacional (2016) constataram que a sociedade brasileira admite a presença de refugiados, mas assume uma posição de distanciamento em relação a eles, uma vez que os considera como elementos estranhos que vieram usufruir de benefícios supostamente exclusivos daqueles que nasceram e residem no Brasil ou, ainda, que sustenta a ideia de que eles vieram sobrecarregar os serviços oferecidos pela já parca infraestrutura pública brasileira. Essas crenças são as lamentáveis consequências da falta de diálogo, orientadas por uma atitude, conforme já discutimos, de mera tolerância.

Nessa conjuntura, aqueles que se encontram na condição de refugiados são tolerados, mas não são efetivamente acolhidos. Essa forte resistência ao diálogo apresenta graves consequências, tais como a marginalização de grupos minoritários, mascarada por uma aparente receptividade que, na prática, enfoca a diversidade cultural como um problema a ser combatido. Alguns dados preocupantes evidenciam as consequências dessa resistência.

De acordo com o balanço de denúncias registradas pelo Disque Direitos Humanos (2017), vinculado ao Ministério da Justiça, em 2015, as queixas apuradas em relação à xenofobia aumentaram em 38\% em relação ao ano anterior. E, apesar de ter sido constatado um sensível recuo nessas estatísticas em 2016, ainda se nota que a discriminação sofrida por estrangeiros, sejam eles refugiados ou não, é uma questão preocupante quando a discussão em pauta refere-se aos direitos humanos.

Rodrigues (2016 apud OLIVEIRA JÚNIOR: 45) propõe um esclarecimento sobre as origens dessas máscaras que encobrem a face dessa resistência. Para o autor, durante o período imperial, houve um forte investimento na propagação de narrativas que sustentam o imaginário de um Brasil acolhedor e pacífico: 
Embora desgastadas pelo tempo, as narrativas sobre um Brasil manso e acolhedor com as diferenças sobrevivem e são invocadas para maquiar a secular dificuldade em conviver com o diverso. Nosso falso pacifismo foi usado como elemento de unificação nacional.

Discutir a configuração de tais narrativas ou até mesmo o histórico de todo esse imaginário não constitui os propósitos do presente estudo. No entanto, quando se discute a questão do contexto do refúgio e das condições em que se encontra o sujeito circunscrito nesse contexto, é preciso considerar todo esse imaginário. O seguinte contrassenso é observável: a sociedade, em coro, afirma-se como acolhedora. Percebem-se, contudo, ecos que evidenciam a rasa aceitação do outro e a "secular dificuldade" que temos de conviver com o diverso, com aquele que não se enquadra nos padrões.

Outros estudiosos amparam essa constatação: Karnal (2016 apud OLIVEIRA JÚNIOR: 42) sugere que, como consequência dessas narrativas de um Brasil "manso e acolhedor", se fundamentou uma discriminação discursivamente velada: se, por um lado, há uma imagem de um povo que aceita e acolhe a todos, por outro, é possível constatar que a aceitação e o acolhimento são efetivamente dirigidos a poucos. Oliveira Júnior (2016) ainda afirma, do mesmo modo e nos entremeios dessa discussão, que há uma aversão muito grande na sociedade brasileira de assumir conflitos. Por essa razão, perpetua-se o mito de que o Brasil é um país pacífico e tolerante em relação às diferenças culturais.

Por detrás desse mito, há uma realidade sociocultural que pode ser compreendida nos termos de Berry (1997) e as suas considerações tecidas sobre as sociedades que são um melting pot - uma panela que derrete os ingredientes - e pressure cook - uma panela de pressão. Ao se ater à análise de diferentes sociedades multiculturais sugere essas duas metáforas.

Nas sociedades enquadradas como melting pots as diferenças linguísticas e culturais são reprimidas com vistas a atingir o objetivo de uma suposta homogeneidade. Nessa conjuntura, o que se fala e o que se ouve nada mais é do que a voz do grupo dominante e as diferentes origens ou heranças do sujeito são reprimidas.

Em suma, em uma melting pot o que realmente importa são os valores de quem detém o poder e a diversidade cultural é marginalizada. Prioriza-se uma sociedade em que todos falam a mesma língua e coexistem de maneira, aparentemente, harmônica. 
Bittens e Jennings-Winterle (2015), ao discutirem o posicionamento de Berry, afirmam que membros de certas sociedades multiculturais têm orgulho de defini-las como um melting pot, em que, na realidade, diversas disputas de poder, trocas de insultos e a falta de respeito e diálogo ocorrem, explicitamente ou não.

Já em sociedades consideradas pressure cooks, as diferenças e tensões culturais são reconhecidas e respeitadas. A partir dessa atitude, torna-se possível propor políticas públicas que podem ser bem-sucedidas ou não e que buscam valorizar a diversidade cultural. Assim, visa-se ao efetivo diálogo, ultrapassando as barreiras da mera tolerância e consequente marginalização e alcançando a convivência.

Assumimos que, no contexto do refúgio, há uma conjuntura sociocultural no Brasil que se aproxima do que Berry (1997) chama de melting pot. Certamente, um melting pot possui padrões que são empregados de modo a estabelecer as razões de se desfigurar quaisquer manifestações linguísticas ou culturais que não estejam em consonância com o grupo dominante. Na condição de refugiado, o sujeito enfrenta as duras penas de uma categorização que rotula a população de migrantes, sejam eles refugiados ou não.

Seyferth (2002: 143) propõe que essa categorização rotula os estrangeiros como desejados e indesejados. Esses rótulos que circulam, segundo a autora, remontam ao período colonial e colocam o estrangeiro ideal, ou seja, o migrante desejado, como "um branco adjetivado, sendo excluídos os doentes, portadores de deficiência física e mental, velhos, criminosos, gente de conduta nociva, refugiados, apátridas e as etnias inassimiláveis". Aqueles que se deslocam sob quaisquer outras condições e não apresentam um perfil que se conforma nesse padrão de estrangeiro, são considerados um fardo e tendem a ficar sujeitos a práticas discriminatórias.

É também de suma importância reconhecer o caráter heterogêneo dos contingentes migratórios que se dirigem ao Brasil no contexto do refúgio e que se contrapõem às expectativas atreladas ao imaginário de estrangeiro ideal: "Desde o final do século XIX, criou-se a ideia de que o migrante para ser aceito teria de ser branco e europeu, e os imigrantes atuais são indígenas que falam espanhol, como os bolivianos, ou negros que falam francês ou crioulo, como os haitianos" (FIORAVANTI, 2015: 18).

Em suma, esse paradigma social é propício à disseminação de estereótipos que se acumulam junto ao rol de barreiras de cunho infraestrutural que dificultam a inclusão social da população refugiada. Em geral, é possível identificar uma série de estereótipos 
que circulam em relação às condições do sujeito que se encontra refugiado. Cardoso (2012: 94) afirma que ou esse sujeito é considerado um criminoso, fugitivo da justiça, ou uma vítima, incapaz de se tornar autônomo e destinado a permanecer um agregado que se beneficia de medidas assistencialistas.

Os estereótipos acerca da identidade do refugiado são construídos e mantidos nos discursos. É comum a verificação de termos que os relacionam à marginalização, ao terrorismo, à preguiça e à falta de interesse ao trabalho. Há também a criação de imaginários sociais nos quais eles são apresentados como vítimas ou infratores: a condição da pessoa sacrificada pelo destino é mantida e há poucos registros sobre a sua busca por um novo posicionamento social.

Certamente, os poucos registros sobre a busca de um novo posicionamento social são encobertos pelas camadas da discriminação e pela falta de conscientização da sociedade sobre quais são os propósitos desse sujeito na sociedade que o acolheu. Ainda faltam iniciativas destinadas a dar voz a esse sujeito do refúgio. O fato de que eles estão inseridos na sociedade é conhecido, mas as suas necessidades fundamentais e a suas histórias jazem encurraladas pelas mãos de um discurso dominador que marginaliza aqueles que estão autorizados a estar aqui, mas sem, no entanto, atuar e conviver ativamente no espaço social.

Em concordância com essas considerações, Rodrigues Neto (2003) ainda observa que, além desses estereótipos, há a desconfiança que a população brasileira sustenta em relação aos estrangeiros que se encontram em condições que fogem ao padrão de migrante ideal. Para o autor, a maioria dos setores da sociedade ainda encara com ressalvas essa posição de suposto acolhimento a refugiados e afirma que o país já enfrenta problemas internos suficientes e é incapaz de assumir os problemas enfrentados por outras nações.

Muitas pessoas, no entanto, olham com desconfiança esta posição do Brasil. Argumentam que já temos problemas internos suficientes para buscarmos resolver os de outros povos. Há ainda os que desconfiam do abrigo conferido a estrangeiros, porque não acreditam na contribuição eficaz que os refugiados, sobretudo de países de Terceiro Mundo, possam trazer para a sociedade brasileira. (RODRIGUES NETO, 2003: 168)

\subsection{Desenraizamento e o contexto do refúgio}

As condições do refúgio são determinadas pelo caráter involuntário e de extrema vulnerabilidade social que as configura. Conforme demonstramos anteriormente, é preciso ter cautela para não confundir diferentes modalidades de deslocamento 
populacional de modo a generalizar de maneira reducionista experiências que estão contextualizadas em circunstâncias diversas.

Sabidamente, os movimentos migratórios não são fatos recentes e datam de épocas bem anteriores à nossa contemporaneidade. Desloca-se desde os primórdios para toda parte e com motivações variadas.

No entanto, tal constatação precisa ser ressalvada. Muitas vezes pode parecer pertinente lançar um olhar para diferentes experiências utilizando as mesmas referências teórico-metodológicas. Com isso, há o risco de se tratar um fenômeno, linguístico ou não, mobilizando um arcabouço de estudo que não é adequado a ele ou que não enquadra e problematiza aspectos que são relevantes e não podem ser descartados.

No caso específico do refúgio, é preciso que haja sensibilidade para não perspectivar o tema com referências que são próprias de um contexto de migração voluntária. Penna (2015: 107), ao tratar de deslocamentos humanos em circunstâncias sociais e econômicas críticas, discute essa questão à luz do conceito de redes de relações:

As condições para estabelecer redes de relações no/com o novo espaço são bastante diferentes quando se trata de migrantes de outra origem social, que têm acesso a bens materiais e culturais, à educação e à profissionalização.

Para o autor, o empreendimento de se deslocar demanda do sujeito a disposição para estabelecer redes de relações culturais, políticas, sociais, econômicas e educacionais, de modo que a integração ao novo espaço social seja viável. Por sua vez, cabe ao novo espaço social oferecer as possibilidades para que essas relações sejam viabilizadas. No entanto, quando a origem social do sujeito dessa experiência não lhe permite estabelecer essas relações ou quando não há subsídios no novo espaço social que amparem tais relações, então a experiência do sujeito é marcada pela marginalização e conseqüente isolamento. A impossibilidade de estabelecer redes de relações é um impedimento ao acesso à cidadania.

Assim, todos migram voluntária ou involuntariamente por diversas razões e essa constatação é indiscutível. Porém, a razão que levou o sujeito a transpor fronteiras importa e atuará como possível fator determinante da experiência enfocada e de como as redes de relações serão estabelecidas. Por meio de um atento olhar às motivações que o orientaram nesse contexto, é possível evidenciar e explicar certos processos que não se dão a conhecer quando ignoramos certas particularidades. 
No que concerne ao contexto do refúgio no Brasil, consideramos que a atual conjuntura e os mecanismos de assistência e de acolhimento do sujeito que se encontra nessa condição ainda são insuficientes, uma vez que os discursos de tolerância e a falta de infraestrutura financiada pelo governo impedem que redes de relações sejam efetivamente construídas. O sujeito, encurralado nessas condições que inviabilizam as redes de relações, vivencia uma complexa experiência de desenraizamento.

\subsubsection{Desenraizamento e infelicidade}

As redes de relações que o sujeito estabelece na sociedade de acolhimento criam um sentimento de pertencimento necessário para que ele consiga integrar-se efetivamente ao espaço social em que ele se encontra. Esse sentimento de pertencimento nos leva a revisitar o que se entende por (des)enraizamento cultural.

O enraizamento, conforme analisado por Weil (1990) é a necessidade mais importante e desconhecida da alma humana. Segundo a autora, o ser humano tem essa necessidade de fincar raízes e, assim, estabelecer relações e referências orientadas pela participação real em sua comunidade. Por meio delas, é possível conservar na memória certos costumes e sustentar certos projetos a serem realizados em longo prazo.

O enraizamento é talvez a necessidade mais importante e mais desconhecida da alma humana. É uma das mais difíceis de definir. O ser humano tem uma raiz por sua participação real, ativa e natural na existência de uma coletividade que conserva vivos certos tesouros do passado e certos pressentimentos do futuro. Participação natural, isto é, que vem automaticamente do lugar, do nascimento, da profissão, do ambiente. Cada ser humano precisa ter múltiplas raízes. (WEIL, 1990: 61)

O que é importante destacar nas considerações tecidas é o termo "participação". Só é possível estar devidamente enraizado se o sujeito puder participar, compartilhar, dialogar e interagir, ações que não podem ser exercidas em um ambiente onde as relações sociais são pautadas na tolerância. Essa participação é um requisito prévio para que o sujeito consiga não apenas preservar a sua herança cultural, mas também atuar ativamente na sociedade e planejar o que ele pretende fazer futuramente.

O inverso do enraizamento é justamente o desenraizamento. Esse processo pode ser entendido como o resultado de circunstâncias que abalam a participação social do sujeito, deixando-o às margens, como se ele, sem raízes, flutuasse como um espectro mudo, cuja história de vida não importa e que não é autorizado a ter voz ativa e a 
exercer seus direitos e deveres. Sem raízes, o sujeito torna-se facilmente dominado e impedido de resistir aos abalos da dominação.

O desenraizamento é, evidentemente, a mais perigosa doença das sociedades humanas, porque se multiplica a si própria. Seres realmente desenraizados só têm dois comportamentos possíveis: ou caem numa inércia de alma quase equivalente à morte, como a maioria dos escravos no tempo do Império Romano, ou se lançam numa atividade que tende sempre a desenraizar, muitas vezes por métodos violentíssimos, os que ainda não estejam desenraizados ou que estejam só em parte. (WEIL, 1976: 351)

Os contextos em que o processo de desenraizamento é provocado variam. Mas todos são marcados pelo que Weil (1976) chama de "experiência de infelicidade". Para a autora, essas circunstâncias desenraizadoras abalam o sujeito de tal modo que a sua própria humanidade é anulada perante as relações de dominação. É como se alguém repetisse ao pé do ouvido do sujeito desenraizado, sem que ele tenha o direito de resposta, que ele é de fora e não tem direito a participar ativamente da sociedade. Sua marginalização é reafirmada sem que ele possa se defender:

Como se alguém repetisse ao ouvido de minuto a minuto, sem que se possa responder nada: "Você não é nada aqui. Você não conta. Você está aí para curvar-se, suportar tudo e calarse". Semelhante repetição é quase irresistível. Chega-se a admitir no âmago de si mesmo, que não se é nada. (WEIL, 1976: 132)

A experiência da infelicidade recai sobre o sujeito de tal maneira aterradora que suas reverberações conduzem-no, marginalizado, à apatia e ao isolamento. Desse modo, ele fica incapaz de questionar a situação de marginalização em que ele se encontra; o discurso de dominação o arrebata de tal modo que ele mesmo não consegue reconhecer que se encontra dominado. Essa infelicidade é misteriosa para os desenraizados, incapacitados de falar e até mesmo escrever a esse respeito, pois, segundo Weil (1975: 130), "a primeira consequência da infelicidade é que o próprio pensamento se quer evadir; não quer considerar a desgraça que o fere".

No caso do refúgio, parece claro que se trata de um contexto que pode se configurar de tal modo que submete o sujeito a um processo de desenraizamento, sobretudo quando as políticas de integração não conseguem promover de fato a integração proposta ou quando discursos que propagam a discriminação se fazem presentes. Impedido de manter suas heranças linguísticas e culturais, categorizado como um estrangeiro "indesejado" que se encontra em condições de vulnerabilidade social, o sujeito do refúgio pode tornar-se um sujeito desenraizado no país que lhe concedeu refúgio. 
Apesar de ser difícil de situar quando se principia um processo de desenraizamento, é apropriado propor algumas hipóteses. Conforme Weil (1976) explana, é possível hipotetizar que o processo se inicia quando as redes de relações do sujeito são rompidas ou quando o sujeito, após engajar-se em preservar suas relações pretéritas, é impedido de estabelecer novas relações.

Há, ainda, autores que afirmam que o sujeito, no contexto dos deslocamentos humanos, já chega ao lugar de destino desenraizado, principalmente quando se trata de uma modalidade de deslocamento humano que ocorre em circunstâncias críticas como é o caso do refúgio. Penna (1998) afirma que o desenraizamento não acontece no lugar do destino, mas, sim, no país de origem. Nessa perspectiva, o sujeito na condição de refugiado já se encontra desenraizado quando chega à sociedade de acolhimento, onde o processo de desenraizamento avança.

Apesar das hipóteses apresentadas revelarem aspectos interessantes do processo de desenraizamento, não nos cabe, nessa ocasião, discutir quando o processo de desenraizamento se inicia. No entanto, a configuração desse processo de desenraizamento que o sujeito sofre na sociedade que lhe concedeu o refúgio nos interessa, uma vez que está fundamentalmente atrelada aos valores atribuídos às suas referências culturais e linguísticas e à cidadania que lhe é, supostamente, assegurada pelos mecanismos institucionais e jurídicos.

\subsection{Cidadania no contexto do refúgio}

O conceito de cidadania qualifica o sujeito como um participante da vida do Estado e como uma pessoa efetivamente integrada à sociedade. Nesses termos, a dignidade da pessoa humana é garantida, por meio do cumprimento de deveres e do exercício de direitos à educação, à moradia, à saúde e ao mercado de trabalho.

A cidadania está aqui num sentido mais amplo do que o de titular de direitos políticos. Qualifica os participantes da vida do Estado, o reconhecimento do indivíduo como pessoa integrada na sociedade estatal (art. $5^{\circ}$, LXXVII). Significa aí, também que o funcionamento do Estado estará submetido à vontade popular. E aí o termo conexiona-se com o conceito de soberania popular (parágrafo único do art. $1^{\circ}$ ), com os direitos políticos (art. 14) e com o conceito de dignidade da pessoa humana (art. $1^{\circ}$, III), com objetivos da educação (art. 205), com base e meta essencial do regime democrático. (SILVA, 2009: 104)

O estatuto do refugiado instaurado pela Lei 9.474, ao adotar uma definição mais ampliada de quem são aqueles que estão aptos a solicitar refúgio no Brasil, assegura, 
teoricamente, a cidadania do sujeito que se encontra nessa condição. De acordo com o Artigo $5^{\circ}$, o sujeito, enquanto refugiado, tem a sua cidadania assegurada por vias jurídicas e institucionais:

Art. $5^{\circ} \mathrm{O}$ refugiado gozará de direitos e estará sujeito aos deveres dos estrangeiros no Brasil, ao disposto nesta Lei, na Convenção sobre o Estatuto dos Refugiados de 1951 e no Protocolo sobre o Estatuto dos Refugiados de 1967, cabendo-lhe a obrigação de acatar as leis, regulamentos e providências destinados à manutenção da ordem pública.

No entanto, o que é postulado pela lei é discutível. Primeiramente, apesar de nela constar que o sujeito refugiado "gozará de direitos", é o tom genérico dessa afirmação que preocupa e que dá margem para que, na dimensão prática da atuação social, o sujeito refugiado permaneça marginalizado. Além disso, o termo "deveres dos estrangeiros" já nos leva a questionar em que medida a integração social no contexto do refúgio se realiza efetivamente.

Assim, se, por um lado, a Lei 9.474/97 assegura a cidadania daqueles que se encontram nessa condição, por outro, na condição de refugiado, o sujeito não tem direito a votar ou ainda de ocupar cargos políticos em nível estadual, municipal ou federal. Para ter seu diploma reconhecido, é preciso dar entrada a um processo que, além de longo, é financeiramente custoso. Logo, parece que a manutenção da cidadania para o sujeito do refúgio sofre uma série de restrições e não está em condições de equidade com os demais membros da sociedade que não se encontram na condição de refugiado.

Cidadania é, então, o direito de participar da vida comunal, por estar nela integrada. E o refugiado, para não perder sua humanidade, necessita de integração na comunidade que o recebe. Para tanto, deve contar com o direito a ter e exercer direitos, com as restrições, no entanto, inerentes à sua condição de estrangeiro. (NASCIMENTO, 2014: 57)

O contrassenso parece evidente: é proposta, assegurada e defendida a cidadania do sujeito na condição de refugiado, porém, há uma série de ressalvas que, na realidade, impossibilitam a participação efetiva na sociedade que the concedeu refúgio. Não parece viável estar integrado se, concomitantemente, o sujeito fica circunscrito nas restrições "inerentes a sua condição de estrangeiro". Portanto, essa cidadania assegurada em lei não parece conseguir ultrapassar os limites dos incisos constitucionais e acaba, de fato, mascarando a situação de marginalização do sujeito refugiado.

Essas constatações nos conduzem a discutir a humilhação social e a angústia oriundas da situação em que a própria humanidade do sujeito é ameaçada, uma vez que ele é impedido de cultivar o sentimento de pertença oriundo da participação efetiva em 
sua comunidade. Cabe citar brevemente, para essa ocasião e com vistas a ilustrar e finalizar as considerações tecidas até então, Arendt (2004: 331): "Só a perda da própria comunidade que o expulsa (o sujeito) da humanidade".

\subsubsection{Angústia e humilhação social}

A experiência do refúgio, compreendida como uma experiência de humilhação social, evidencia aspectos atrozes da dominação que o sujeito nessa condição enfrenta. Para tornar tal constatação mais clara, é preciso esclarecer mais detalhadamente o que assumimos como humilhação social. Para Gonçalves (1998, p. 43), a humilhação social é, sobretudo, um fenômeno de cunho político e histórico que reverbera na subjetividade e incide na dimensão identitária do sujeito. $\mathrm{O}$ autor afirma:

Sem dúvida, trata-se de um fenômeno histórico. A humilhação crônica, longamente sofrida pelos pobres e seus ancestrais, é efeito da desigualdade política, indica a exclusão recorrente de uma classe inteira de homens para fora do âmbito intersubjetivo da iniciativa e da palavra. Mas é também de dentro que, no humilhado, a humilhação vem atacar. A humilhação vale como uma modalidade de angústia e, nesta medida, assume internamente como um impulso mórbido - o corpo, o gesto, a imaginação e a voz do humilhado.

Assim, a experiência do refúgio, por submeter o sujeito a uma condição de vulnerabilidade social e por deixá-lo impedido de atingir a plena cidadania, pode ser considerada como uma experiência de humilhação social. Diante de um discurso que o coloca na posição de um estrangeiro indesejado e que mascara preconceitos velados e ceifa oportunidades de integração efetiva, o sujeito é acometido pela angústia de estar excluído sem necessariamente compreender com clareza como tal exclusão se configura e como ele pode superá-la.

Gonçalves (1998) ainda afirma que a humilhação social conhece, em seu mecanismo, determinações econômicas e inconscientes e é, nesses termos, uma modalidade de angústia disparada pelo enigma da desigualdade. Esse fenômeno é simultaneamente psicológico e político, uma vez que o sujeito dessa condição, no caso o sujeito do refúgio, atravessa uma situação de impedimento para a sua humanidade e preservação de suas referências culturais - sua gastronomia, suas canções, suas histórias, o exercício de seu ofício - e, sobretudo, a sua língua.

Como tal, trata-se de um fenômeno ao mesmo tempo psicológico e político. O humilhado atravessa uma situação de impedimento para a sua humanidade, uma situação reconhecível nele mesmo - em seu corpo e gestos, em sua imaginação e em sua voz - e também reconhecível em seu mundo - em seu trabalho e em seu bairro. (GONÇALVES, 1998: 15) 
Especificamente no que concerne a questões linguísticas, o sujeito do refúgio, nesse contexto de humilhação social, tem como língua estrangeira a língua portuguesa. No entanto, as iniciativas dedicadas ao ensino de língua portuguesa ficam restritas aos parcos incentivos governamentais às quais muitos refugiados não têm acesso. Esse problema, além de repercutir no cotidiano dessas pessoas, é ampliado em nível institucional. Muitos locais de atendimento à população refugiada não dispõem de intérpretes e tradutores, ou então dispõem insuficientemente de profissionais qualificados para o exercício de tais funções.

A história do sujeito do refúgio nessas condições, muitas vezes equivalente a tudo o que ele traz consigo e a comunicação, , é golpeada pela falta de subsídios que a ampare. Intensifica esse golpe a falta de ouvintes que estejam disponíveis e qualificados para ouvi-lo. Nesses termos, pedir uma simples informação na rua pode ser mais doloroso do que parece; falar a sua língua materna pode fazer doer, pois expõe a condição de migrante não ideal e isso, numa sociedade em que são articuladas práticas discriminatórias, é humilhante. Kristeva (1994) chama essa situação de "o silêncio dos poliglotas": calar-se parece ser uma atitude de autopreservação.

Para superar esse silêncio, diferentes condutas podem ser observadas. O sujeito pode formar núcleos com seus compatriotas, nos quais se fala apenas a sua língua materna, atando, assim, um forte vínculo. Outra opção que resta é o sujeito lançar-se numa busca desenfreada pela língua estrangeira, a língua do país que concedeu o refúgio, com vistas a se sentir parte dessa nova realidade de vida. Ater-nos-emos a essa última conduta de busca pela língua estrangeira.

Em sua avidez por aprender essa língua, o sujeito pode sustentar a crença de que precisa abdicar de sua língua materna e de suas outras referências culturais. Essa encruzilhada linguístico-cultural é resultado da situação de humilhação social a que ele é submetido. Ao sofrer o duro golpe da dominação desferido por um contexto de discriminações veladas, o sujeito sente-se imbuído a habitar uma língua que ainda não lhe é familiar. Sob o teto dessa língua, ele acredita estar protegido de situações desalentadoras, tais como não compreender os questionáveis pormenores jurídicos de sua "condição de estrangeiro" ou, ainda, não conseguir candidatar-se a uma vaga de emprego.

Essas questões práticas amortecem o discurso de um não respeito, aparentemente gentil, que determina quem é de fora e não se enquadra em certos padrões de migrante 
ideal ou, ainda, que determina que um sujeito na condição de refugiado tem a sua cidadania garantida, mas que tal cidadania não será plena. Assim, o sentimento de angústia que assola o sujeito no processo de aquisição de língua estrangeira não deve ser compreendido como algo isolado, atrelado somente ao momento da aula e orientado por questões meramente profissionais. A angústia que esse sujeito sente, enquanto está sentado em sua carteira, é motivado por golpes que são desferidos nas relações de dominação que pretendem ignorar as diferenças que não estão previstas na definição de migrante ideal e que, por essa razão, são desconfortáveis.

Conforme afirmação contida no relatório do Instituto Adus de Reintegração ao Refugiado (2016, p. 138),,sem domínio da língua, não se pode alcançar um trabalho digno, mas esse processo de aprendizagem não é livre de dores: “A aprendizagem de língua portuguesa pode trazer dificuldades e angústia, já que o conhecimento da língua é importante para que o refugiado consiga trabalho no país". Essa afirmação, apesar de sua pertinência, é questionável. Inegavelmente, aprender uma língua estrangeira é um processo que pode gerar angústia, mas é preciso cautela para que a dimensão da questão não seja reduzida de modo a considerar que a única finalidade que orienta esse processo é a busca por um emprego. 


\section{II - Identidade e língua no contexto do refúgio}

As condições do refúgio expõem o sujeito à experiência da incerteza e do desenraizamento. Ao reivindicar o seu lugar e os seus direitos em um espaço fora do país de origem, esse sujeito enfrenta uma situação de crise identitária que o faz questionar suas vivências pretéritas e o coloca em posição de confrontamento com as suas próprias referências culturais. A incerteza proveniente de um deslocamento forçado, que não foi previamente planejado como se planeja um intercâmbio acadêmico ou ainda uma transferência de emprego, se junta à estranheza de ouvir falares que não são familiares ao sujeito ou de se deparar com outras formas de se vestir e de se comportar em lugares públicos.

Conforme Dantas et al (2010, p.48) explanam, a experiência do deslocar-se possui uma dimensão psicossocial que abala as estruturas do que é suposto como fixo e estável.

Fica claro, portanto, que o contato contínuo com outra cultura supõe um conflito, crise e uma posterior 'adaptação' ao novo ambiente cultural. Interessante lembrar que a palavra crise, em chinês, é formada por dois ideogramas, em que um significa perigo e o outro significa oportunidade. Há, portanto, a possibilidade dessa crise ser insuperável, devido a uma série de fatores situacionais e internos, assim como a possibilidade da mudança poder significar ampliação do self, transformação.

Reconhecer que a condição do refúgio configura uma situação de humilhação social que possui uma dimensão histórica e identitária nos leva a rejeitar conceito de identidade que a toma como uma entidade inerente, permanente e estável. A essência do sujeito, algo supostamente estático, não coaduna com uma discussão que assume o refúgio como um fenômeno de humilhação social decorrente de processos de desenraizamento que causam angústia e o colocam em uma situação de evidente crise identitária. Pelo contrário, tais questões nos levam a reconhecer que as identidades são processos, dinâmicos e instáveis.

A identidade não é uma essência: não é um dado ou um fato - seja da natureza, seja da cultura. A identidade não é fixa, estável, coerente, unificada, permanente. A identidade tampouco é homogênea, definitiva, acabada, idêntica, transcendental. Por outro lado, podemos dizer que a identidade é uma construção, um efeito, um processo, uma relação, um ato performativo. A identidade é instável, contraditória, fragmentada, inconsistente, inacabada. (SILVA, 2012: 97) 
A relação entre língua e identidade é multifacetada e pode ser apreendida, por exemplo, quando observamos os diferentes mecanismos que articulam o que se entende por "narrativas da nação". Para Hall (2014), as narrativas da nação são veiculadas nas histórias e nas literaturas nacionais, na mídia e na cultura e fornecem respaldo para que seja criado um senso de identidade nacional que faz com que todos se sintam vinculados entre si em uma comunidade imaginada:

Em primeiro lugar, há a narrativa da nação, tal como é contada e recontada nas histórias e nas literaturas nacionais, na mídia e na cultura popular. Essas fornecem uma série de histórias, imagens, panoramas, cenários, eventos históricos, símbolos e rituais nacionais que simbolizam ou representam as experiências partilhadas, as perdas, os triunfos e os desastres que dão sentido à nação. Como membros de tal "comunidade imaginada", nos vemos, no olho de nossa mente, como compartilhando dessa narrativa. Ela dá significado e importância à nossa monótona existência, conectando nossas vidas cotidianas com um destino nacional que preexiste a nós e continua existindo após a nossa morte. (HALL, 2014: 31)

A transmissão dessas narrativas que articulam uma suposta cultura dominante pode se dar por meio de uma língua, a língua oficial, que viabiliza um senso de identidade nacional que ata ouvintes e narradores. Como se todos falassem em um mesmo tom e, nesse coro aparentemente monolíngue, não são admitidos aqueles que falam outras línguas e destoam do compasso dominante:

A formação de uma cultura nacional contribuiu para criar padrões de alfabetização universais, generalizou uma única língua vernacular como o meio dominante de comunicação em toda a nação, criou uma cultura homogênea e manteve instituições culturais nacionais, como, por exemplo, um sistema educacional nacional. (HALL, 2014: 30)

Quando enfocamos o contexto do refúgio, o plurilinguismo das vozes que destoam do coro dominante assume particular importância, pois revelam o impacto da dominação cultural em termos linguísticos. Bosi (1987: 16) afirma que, quando duas culturas se defrontam, não necessariamente como predador e presa, mas como diferentes formas de existir, uma é para outra como uma revelação. No entanto, "essa experiência raramente acontece fora dos polos de submissão". Como inevitável consequência, a cultura dominada - e, por conseguinte, a língua dominada - perde os meios materiais de se expressar.

Se as considerações tecidas por Bosi (1987) forem passíveis de confirmação, então no contexto do refúgio, o sujeito que se encontra nessa condição se verá abruptamente forçado a aprender a língua oficial do país que lhe concedeu refúgio. Nessa dinâmica, a desvalorização de sua língua materna é passível de ocorrer, o que faz com que esse falante não a transmita para as próximas gerações. 
De acordo com o Relatório do Ministério da Justiça (2016), a língua é considerada a maior dificuldade enfrentada pelos estrangeiros na sociedade brasileira estejam eles na condição de refugiados ou não. As queixas são orientadas por diversos motivos: dificuldade em obter atendimento em instituições públicas e privadas, em realizar tarefas cotidianas, em alcançar uma colocação profissional condizente com a sua formação acadêmica, entre outros.

A língua também é indicada pelo relatório como a maior barreira para superar a discriminação. A questão que se coloca é: como reivindicar seu espaço e seus direitos se a língua oficial permanece um enigma e quando a língua materna do sujeito é igualmente considerada um enigma a ser ignorado pela sociedade?

\section{1. Às provas da língua estrangeira}

O desafio linguístico de dominar um novo idioma no contexto do refúgio pode ser sucintamente compreendido por meio da explanação de Araújo (2003):

$\mathrm{O}$ refugiado vive em sua plenitude um drama duplo: o de se fazer entender e o de buscar entender as pessoas. $\mathrm{O}$ fracasso em vencer este desafio dá origem a vários outros obstáculos, como o de ser constantemente ridicularizado por não conseguir se expressar corretamente, gerando muitas, confirmação de sua insegurança o que, de um modo geral, é decisivo para conservar a sua baixa autoestima. Por outro lado, é reconhecido como uma motivação básica, buscar o seu espelho naqueles que detêm o domínio de sua própria língua. Isto leva o refugiado a se fechar em pequenos nichos onde o que existe de mais sólido é o ponto comum que os iguala. (ARAÚJO, 2003: 41)

Ao abordarmos a questão linguística no contexto do refúgio, é necessário reconhecer que, uma vez levantada a barreira linguística, o sujeito passa a enfrentar entraves em sua rotina, além de sofrer preconceito linguístico que abala o seu processo de adaptação no novo país de residência. Além disso, a barreira linguística pode contribuir para a marginalização e consequente exclusão do sujeito refugiado, que, ao visar à sobrevivência, se reúne em pequenos núcleos sociais. Tais núcleos passam a representar nichos de resistência perante as dificuldades apresentadas.

Aprender e dominar uma língua apresenta, de fato, um inegável viés de cunho prático. No entanto, se considerarmos que a aprendizagem de uma língua é um processo social e que as identidades não são fixas e são confrontadas pelo entorno social, então o aspecto identitário deve ser devidamente considerado.

Revuz (2001: 227) afirma, contudo, que aprender uma língua consiste em tornarse um outro, rompendo e atando vínculos em um processo que pode ser abrupto, 
principalmente se for acompanhado por um deslocamento pautado em condições de vulnerabilidade social:

Essa dupla experiência de ruptura ou perda e de descoberta ou apropriação é mais violenta quando ela é acompanhada de uma ruptura real (emigração, estada no estrangeiro), mas está presente também de modo mais silencioso, mesmo nas aprendizagens mais esparsas e escolares.

Submeter-se à aprendizagem de uma língua que lhe é estranha em circunstâncias sociais críticas é um processo que pode apresentar reverberações dolorosas na subjetividade. Para acolher essas reverberações de maneira respeitosa e com vistas a não depreciar as referências culturais do sujeito que está refugiado, é preciso que haja vigorosas iniciativas de conscientização sobre a importância de refletir sobre questões linguísticas. Afinal, o contexto do refúgio impõe à sociedade de acolhimento uma realidade culturalmente diversa que só pode ser devidamente abordada se for estabelecida uma fala, um diálogo intercultural.

\subsection{Ensino de língua portuguesa no contexto do refúgio}

No Brasil, as iniciativas dedicadas ao ensino de língua portuguesa no contexto do refúgio têm sido providas majoritariamente por organizações da sociedade civil. Apenas para citar algumas iniciativas educacionais, cabe destacar as propostas vinculadas à Missão Paz de São Paulo, ao Instituto Adus de Reintegração ao Refugiado de São Paulo, à Cáritas do Rio de Janeiro, bem como propostas amparadas pelo ensino superior público, como o projeto de oferta de cursos de língua portuguesa pela Universidade de Brasília e pela Universidade Federal de São Paulo. Outras iniciativas educacionais também têm apresentado resultados promissores, mas, para esta ocasião, limitar-nos-emos apenas a listar algumas.

O ensino de língua portuguesa - LP - no contexto do refúgio é essencial para que o sujeito que se encontra nessa situação consiga tanto conhecer seus direitos e deveres, bem como reivindicá-los e propor melhorias. As aulas devem ser planejadas de modo a capacitar seus alunos a circular no país de refúgio com autonomia e conduzidas de modo a reconhecer as necessidades e dificuldades cotidianas enfrentadas por eles.

Para os professores algumas questões práticas precisam ser consideradas. Muitas vezes um grupo que será atendido no curso de LP pode ser composto por diferentes nacionalidades. Ensinar, nesse contexto, é uma tarefa que demandará sensibilidade para 
perceber os diferentes valores e heranças culturais presentes em sala de aula. Outra questão a ser considerada são os diferentes níveis de escolaridade que farão parte de um mesmo grupo. Isso se manifesta porque, oriundos de países que apresentam outras realidades sociais, é de se esperar que a experiência escolar dos alunos que estão refugiados seja diversificada, e esse fator irá influir na abordagem dos conteúdos. Há, ainda, a questão emocional e psicológica; não raramente, o sujeito que se refugia em um país vivenciou ou testemunhou situações traumáticas e privação dos direitos básicos. Essas experiências podem abalar o sujeito de modo a comprometer as suas capacidades de concentração e interação em sala de aula.

Barbosa e São Bernardo (2014: 271) discutem essas questões e ressaltam a importância do diálogo intercultural nesse contexto de ensino composto por tamanha diversidade linguística e cultural:

Em se tratando do ensino de português como língua estrangeira, é essencial que um curso ofereça a capacitação linguística necessária à comunicação e aos afazeres do dia-a-dia; portanto, o desenvolvimento da competência comunicativa dos alunos e, consequentemente, das subcompetências que a compõem, incluindo a intercultural - é de extrema importância. Isso implica não somente desenvolver a habilidade linguística, mas concomitantemente expandir o conhecimento cultural e a capacidade de interação cultural, propiciando ao aprendente desenvolver uma sensibilidade cultural, ou ainda, uma fluência cultura, permitindo que o aluno se conscientize das diferenças culturais e como estas interferem na interação e na comunicação, facilitando a integração dessas pessoas à sociedade que os acolhe.

O diálogo intercultural é multifacetado e dá margem a muitas discussões, sobretudo discussões de cunho linguístico. Nesse ambiente de trocas e aprendizado, a relação do sujeito com a(s) sua(s) língua(s) materna(s) e com a língua estrangeira, no caso a LP, se (re)definirá a partir da sua experiência de acolhimento proposta em sala de aula. Cabe, então, observar atentamente as tensões e dinâmicas estabelecidas entre língua(s) materna(s) e língua estrangeira e, consequentemente, línguas de herança.

\subsection{Língua materna e língua estrangeira: um embate, um encontro}

A língua materna, doravante LM, é a primeira língua do sujeito. Há contextos em que se identifica uma única LM, outros em que há mais de uma. Segundo Revuz 
(2001), a LM é a língua em que se dá a iniciação social do sujeito nas fases mais iniciais da primeira infância, período que, em média, se estende até os 4 anos de idade ${ }^{2}$.

A LM se internaliza de tal forma que o falante tem a sensação de nunca a ter adquirido; é como se ela simplesmente sempre tivesse "estado lá":

Esse estar-já-aí da primeira língua é um dado ineludível, mas essa língua é tão onipresente na vida do sujeito, que se tem o sentimento de jamais tê-la aprendido, e o encontro com uma outra língua aparece efetivamente como uma experiência totalmente nova. A novidade, entretanto, não está no encontro com o fenômeno linguístico como tal, mas nas modalidades desse encontro. (REVUZ, 2001: 215)

O processo de aquisição de LM é espontâneo, faz-se por meio da interação do sujeito com o seu contexto social e se desenvolve antes que a criança domine a habilidade de articulação da fala. Isso se deve, sobretudo nessa fase inicial da primeira infância, às necessidades básicas dessa criança serem nomeadas e atendidas por aqueles que se encontram em seu entorno. Bittens e Jennings-Winterle (2015: 63) afirmam que aqueles que se encarregam dos cuidados com esse bebê, sejam eles os pais ou não, hipotetizam com base nas suas referências passadas aquilo que a criança pode estar precisando:

A comunicação dos (e com os pais) é o que embasará os conceitos que serão formados ao longo dos primeiros anos de vida do bebê, em se tratando do aparelho mental. Rotulamos de "conceitos" a nomeação das experiências vividas. Ter um filho, na maioria dos casos, traz a oportunidade de reviver a própria experiência de quando fomos bebês, o que explicaria assim a famosa 'intuição' materna e paterna. Os pais, que foram bebês um dia, viveram a mesma experiência emocional de nomeação dos conceitos, na língua materna, que seus bebês estão vivenciando.

No avançar da escala de desenvolvimento infantil, processa-se por meio da interação a introjeção de valores linguísticos e sociais. Para Chulata (2016) esse sistema de valores inatos da língua materna vai determinar o que é permitido dizer e o que não é permitido dizer, de modo a condicionar social e linguisticamente a vida do falante.

Outras línguas adquiridas posteriormente podem ser consideradas como segundas línguas ou línguas estrangeiras - doravante LEs. Sua aquisição, ao contrário da língua materna, não se dá de maneira espontânea e ocorre à luz das LMs. Aprender uma nova língua é uma experiência viabilizada pela recorrência ao referencial linguístico da LM, uma vez que foi ele que proporcionou o acesso à linguagem:

\footnotetext{
${ }^{2}$ Consideramos esse período em conformidade com as contribuições de Bittens e Jennings-Winterle (2015: 64), que assumem como primeira infância a fase de desenvolvimento do bebê que dura, em média, até os 4 anos de idade.
} 
(...) a língua estrangeira é por definição, uma segunda língua, aprendida depois e tendo como referência uma primeira língua, aquela da primeira infância. Pode-se aprender uma língua estrangeira somente porque já se teve acesso à linguagem através de uma outra língua. Essa língua chamada "materna" pode não ser a da mãe, a língua "estrangeira" pode ser familiar, mas elas não serão jamais da mesma ordem. (REVUZ, 2001: 2015)

Discorrer sobre o que diferencia LM e LE é uma tarefa que pode ser conduzida quando se contrasta o saber uma língua e o conhecer uma língua. Nos termos de Melman (1992), saber uma língua consiste em ser falado por ela; o que ela fala em você se enuncia pela sua boca. Em contrapartida, conhecer uma língua é ser capaz de traduzir mentalmente a língua que se sabe para a língua que se pretende conhecer. Dessa articulação entre saber e conhecer é que se dá o enlace entre LM e LE ${ }^{3}$.

O enlace entre LM e LE também nos leva a reconhecer as línguas de herança. Chulata (2016: 6) afirma que as línguas herança, cujo "valor teórico e aplicado exatamente no espaço de confronto entre a língua materna e a(s) língua(s) estrangeira(s)". Assim, no contexto dos deslocamentos humanos, a língua materna da família que migra ou que solicita refúgio, pode se converter em uma língua de herança quando transmitida às próximas gerações.

Nesse processo de enlaçamento, a LE oferece outras referências para que o sujeito possa se expressar, de modo que ele é colocado a questionar o complexo de valores que nele estão inscritos pela LM. O encontro entre LE e LM, apesar de enriquecedor, estilhaça o que o sujeito acreditava ser fixo e único: os seus valores e a sua visão de mundo sobre o seu entorno social. Afinal, conforme Hall (2014: 25) constata, falar uma língua não significa expressar nossos pensamentos mais interiores e originais: “(...) significa também ativar a imensa gama de significados que já estão embutidos em nossa língua e em nossos sistemas culturais".

Para ilustrar essas reflexões, faz-se necessário discutir brevemente um exemplo que demonstra na prática o que está sendo alinhavado em termos teóricos. Em alemão, há quatro cumprimentos: Guten Morgen, Guten Tag, Guten Abend e Gute Nacht. A expressão Guten Morgen é empregada exclusivamente pela manhã e numa tradução direta significa "Boa manhã"; Guten Tag é uma expressão empregada ao longo do dia, do fim da manhã até o período em que o sol se põe e significa "Bom dia"; já, Guten

\footnotetext{
${ }^{3}$ A aquisição de uma LE pode até visar um saber que é próprio da LM, mas esse tópico não será debatido no presente estudo.
} 
Abend é falado a partir do cair da noite, e Gute Nacht é usado exclusivamente para fins de despedida no período noturno, como quando a pessoa vai se recolher para dormir. Em português, há três cumprimentos: bom dia, usado pela manhã; boa tarde, usado à tarde e boa noite, usado à noite.

Apesar de parecer algo banal, esses diferentes cumprimentos demonstram diferentes formas de recortar a passagem do tempo ao longo do dia. Essas particularidades não são algo trivial e evidenciam a complexidade desse encontro entre LM e LE, o qual também pode ser entendido como um embate entre LM e LE. Essa experiência é potencialmente enriquecedora e repercute de tal forma no sujeito que pode ora agregar novos valores, ora estilhaçar os valores que constituem o ponto de vista do sujeito, até então aparentemente inquestionável e único.

É preciso, ainda, fazer uma ressalva antes de prosseguirmos as reflexões propostas. Quando se afirma que o encontro entre LM e LE abala os valores em que o sujeito se encontra inscrito, não estamos sugerindo que esses valores são estáveis. Muito menos sugerimos que tal estabilidade só é afrontada quando o falante se submete ao processo de aprendizagem de uma LE. Muito pelo contrário, consideramos, conforme já mencionado, as identidades como sendo complexos compostos por valores dinâmicos e instáveis. No entanto, tais complexos, na percepção do próprio sujeito, podem ser assumidos como inequívocos e inquestionáveis, talvez por serem tão familiares a ele. A aquisição de LE catapultaria um processo revelador do dinamismo e da instabilidade desses valores.

O que estilhaça ao contato com a língua estrangeira é a ilusão de que existe um ponto de vista único sobre as coisas, é a ilusão de que existe um ponto de vista único sobre as coisas, é a ilusão de uma possível tradução termo a termo, de uma adequação da palavra à coisa. Pela intermediação da língua estrangeira se esboça o descolamento do real e da língua. (REVUZ, 2001: 223)

No caso do refúgio, esse encontro/embate nos leva a dar especial atenção às condições de vulnerabilidade social que configuram a situação em questão. Apesar de não ser possível mensurar objetivamente de que modo as condições de vulnerabilidade abalam o sujeito em comparação como o abalo sofrido por um migrante que se desloca por outras razões que não sejam as razões enumeradas na Declaração de Cartagena (1984), há considerável desconforto teórico e metodológico em propor que ambas as experiências de aquisição de LE são totalmente equiparáveis. Isso ocorre porque ambas as experiências acabam conduzindo o sujeito a reavaliar, de diferentes formas, os valores atribuídos tanto à língua materna quanto à língua estrangeira. 


\section{III - Princípio da Valoração}

As particularidades que delineiam o contexto do refúgio nos permite afirmar que o sujeito fica à deriva: as dores do passado, atreladas a trajetórias marcadas por privação de necessidades básicas, perseguição, fome e ameaças, se combinam com as incertezas do seu futuro e com a dificuldade de integração. Dessa combinação complexa pode emergir a urgente necessidade de sobreviver e preservar a integridade da sua família por meio de contínuos esforços de distanciamento das suas raízes. Esquecer se torna a prerrogativa dessa condição.

O princípio da Valoração proposto por Damásio (2011) nos oferece uma percepção enriquecedora sobre o tópico da sobrevivência. $O$ autor emprega um arcabouço teórico que parte das ciências biológicas, especificamente da neurociência, para abordar fenômenos socioculturais.

Inicialmente, ao alinhavar o escopo teórico do Princípio da Valoração, o autor discorre sobre os mecanismos biológicos da homeostase corporal, que equivale a um processo encarregado de manter o funcionamento metabólico do organismo; ou seja, para que o corpo funcione adequadamente, é preciso que as funções orgânicas estejam ajustadas de modo que a sobrevivência do organismo seja assegurada.

A título de exemplificação e com vistas a tornar o conceito mais claro, cabe citar alguns exemplos: quando a pele sofre um corte, será desencadeada uma série de sinapses que provocarão reações químicas de modo que o processo de cicatrização será ativado. Ou quando o organismo é infectado por uma bactéria, as defesas naturais do corpo serão ativadas de modo a restaurar o bem-estar geral do corpo. Em suma, a homeostase, amparada por um complexo de motivações e estímulos que visam à sobrevivência, é responsável pela regulação orgânica. Trata-se de uma série de operações arquitetadas de tal modo que se dá a gestão biológica da vida:

Todas as operações de gestão a que já aludi - encontrar fontes de energia, incorporar e transformar produtos fornecedores de energia, etc. - destinam-se a manter os parâmetros químicos do interior de um corpo (seu meio interno) dentro da mágica faixa compatível com vida. Essa faixa mágica é conhecida como homeostática, e o processo de obtenção desse estado equilibrado chama-se homeostase. (DAMÁSIO, 2011: 61)

Cabe, ainda, atermo-nos mais detalhadamente ao que é considerado sobrevivência por essa proposta. As faixas homeostáticas não são estáticas, por mais que tendam a uma estabilidade com vistas a preservar o bem-estar geral do organismo. 
Anterior a qualquer operação homeostática há a leitura do contexto no qual o corpo se encontra:

\begin{abstract}
A faixa homeostática ideal não é absoluta - varia conforme o contexto no qual o organismo se situa. Próximo aos extremos da faixa homeostática, a viabilidade do tecido vivo declina, e o risco de doença e morte aumenta; em certo setor da faixa, porém, os tecidos vivos prosperam e funcionam com mais eficiência e economia. Funcionar próximo aos extremos da faixa, mesmo que por breves períodos, é na verdade uma vantagem importante em condições de vida desfavoráveis, porém ainda assim é preferível que os estados da vida funcionem perto do intervalo eficiente. (DAMÁSIO, 2011: 69)
\end{abstract}

A sobrevivência seria, então, a condição primordial que servirá de referência para que a arquitetura biológica da homeostase ocorra de maneira bem-sucedida. Essa constatação nos conduz a discutir, finalmente, a função que a atribuição de valores exerce na questão da sobrevivência.

Conforme já discutimos, Damásio (2011) explana que a depender da situação o organismo empreenderá uma leitura encarregada de valorar que processos serão necessários para afiançar a sobrevivência e o consequente funcionamento eficiente do organismo: "O valor biológico aumenta ou diminui ao longo de uma escala indicadora da eficiência dos estados físicos para a vida. De certo modo, o valor biológico é o representante da eficiência biológica" (DAMÁSIO, 2011: 69).

Assim, com base nesses mecanismos de preservação do bem estar, Damásio (2011) propõe o Princípio da Valoração: o valor atribuído a objetos e processos que encontramos em nosso cotidiano se faz mediante uma referência a essa primitiva do valor do organismo, um valor que a seleção natural determinou. Por essa razão, os valores atribuídos tanto a objetos quanto a atividades teriam alguma relação com esse impulso de sobrevivência. Sua hipótese é a de que a valoração dos objetos e processos que encontramos no dia a dia se faz mediante uma referência a essa primitiva do valor do organismo.

Os valores, em conformidade com a proposta de Damásio (2011), são atribuições, positivas ou negativas, sobre o que pode colaborar com a manutenção do bem-estar do sujeito e o que traz segurança a ele em circunstâncias diversas. Aquilo que tende a não promover o bem-estar ou a segurança tende a ser valorado negativamente; o que promove o bem-estar ou a segurança tende a ser valorado positivamente.

Essa hipótese está alicerçada sobre a constatação de que a regulação instintiva e biológica do organismo orientada pela sobrevivência biológica também nos orienta na 
regulação deliberada em processos orientados pela manutenção de nossa sobrevivência social e cultural, por assim dizer:

Quando o cérebro humano começou a engendrar a mente consciente, o jogo sofreu uma mudança radical. Passamos da simples regulação, voltada para a sobrevivência do organismo, a uma regulação progressivamente mais deliberada, baseada em uma mente dotada de identidade e pessoalidade e agora empenhada ativamente não apenas na mera sobrevivência, mas também na busca de certas faixas de bem-estar. Um salto e tanto, ainda que armado, até onde sabemos, sobre continuidades biológicas. (DAMÁSIO, 2011: 81)

Assim, o Princípio da Valoração nos acompanha nas situações sociais de modo que atribuímos valores ao que garantirá, ou não, nosso bem-estar e, consequentemente, a nossa sobrevivência. Com base na crença de que algo poderá nos trazer benefícios certas atitudes em determinado contexto serão paulatinamente assumidas enquanto outras serão gradualmente abandonadas; hábitos ou costumes serão imbuídos de valor enquanto outros serão desvalorizados.

Damásio (2011) ainda afirma que por detrás das relações culturais que foram construídas ao longo dos tempos, é a regulação da vida que continua a ser a nossa principal preocupação; o ser humano enquanto sujeito social promove e acumula leituras que providenciarão a regulação da vida por meio de um conjunto de instrumentos culturais como convenções sociais, leis e crenças religiosas.

A regulação da vida está na raiz de muita coisa que precisa ser explicada na biologia em geral e na humanidade em particular: a existência do cérebro, a existência da dor, prazer, emoções, sentimentos, os comportamentos sociais, as religiões, as economias e seus mercados, as instituições financeiras, os comportamentos morais, as leis e a justiça, política, arte, tecnologia e ciência - uma lista bem modesta, como o leitor pode ver. (DAMÁSIO, 2011: 82)

Quando há um desequilíbrio ou um problema, definido por parâmetros sociais e culturais e que afeta a sobrevivência e o bem estar, serão os impulsos homeostáticos socioculturais que promoverão a restauração do equilíbrio. Isso se faz por meio da reflexão consciente e do planejamento de ação, o sujeito poderá se ver engajado em certos propósitos dedicados a superar essa situação que coloca a sua sobrevivência em risco. Com vistas a esclarecer essa dinâmica, o autor tece as seguintes considerações:

Tanto a homeostase básica, que é guiada de modo não consciente, como a homeostase sociocultural, criada e guiada por mentes conscientes reflexivas, atuam como zeladoras do valor biológico. A variedade básica e a sociocultural da homeostase estão separadas por bilhões de anos de evolução, e, no entanto promovem o mesmo objetivo, a sobrevivência de organismos vivos, embora em diferentes nichos ecológicos. Esse objetivo é ampliado, no caso da homeostase sociocultural, e passa a abranger a busca deliberada do bem-estar. (DAMÁSIO, 2011: 44) 
Ao projetarmos a proposta de Damásio (2011) no contexto que pretendemos analisar, parece evidente que o refúgio se configura de tal forma na sociedade brasileira que o sujeito é colocado numa condição que o torna vulnerável: meramente tolerado e não efetivamente integrado, a sua situação é fundamentada por narrativas históricas que consistem em impedimentos ao acesso e exercício pleno da sua cidadania. Essa experiência de humilhação social que o empurra para fora da sua condição humana e impede o acesso à comunidade nos permite concluir que a condição do refúgio abala o bem estar do sujeito. Nessa condição ele é lançando na encruzilhada da sobrevivência.

Cabe indagar como a LM e a LE serão valoradas pelos impulsos homoeostáticos socioculturais com vistas a promover a sobrevivência do sujeito que se encontra refugiado.

\subsection{O Princípio da Valoração à luz de questões linguísticas}

Se considerarmos que língua e cultura estabelecem entre si uma relação indissociável e que a LM introjeta valores culturais do entorno social e que o processo de aprendizagem de uma LE nos conduz a questionar tais valores e nos defronta com outros valores, então a proposta de Damásio (2011) suscita tanto esclarecimentos quanto questionamentos referentes a contextos sociais e processos identitários.

Ao enfocarmos a relação do sujeito com a sua LM e a LE a ser aprendida no contexto do refúgio, os conceitos de homeostase, sobrevivência e valoração sociocultural parecem proporcionar subsídios enriquecedores para a reflexão sobre como o sujeito irá se relacionar com a língua do país que lhe concedeu refúgio e com a língua do seu país de origem.

Esse sujeito pode sofrer as duras penas de reconhecer que a sua língua materna pode não lhe dar suporte em todas as situações práticas e conversas a serem entabuladas em seu cotidiano. E por mais que haja aparente familiaridade entre a língua oficial de seu país de origem e a língua oficial do país que lhe acolheu, é provável que ele se sinta abalado pela sensação de percorrer um caminho labiríntico pelas vias comunicativas. Paralelamente, esse sujeito, na condição de um "estrangeiro refugiado" ou de um "imigrante não ideal", encontra uma série de impedimentos ao exercício da sua cidadania e à consequente participação na sociedade. Sem poder falar e ser 
compreendido e sem compreender o que lhe é falado, a situação de vulnerabilidade social e de humilhação lhe causa angústia.

Com base no Princípio da Valoração, parece claro que as circunstâncias descritas se enquadram no que o autor considera como uma situação que compromete o bem-estar do sujeito e o lança numa busca pela sobrevivência. Angustiado, o sujeito do refúgio se verá obrigado a empreender as iniciativas cabíveis para que o equilíbrio em seu cotidiano seja restaurado e ele possa tomar parte da comunidade em que ele se encontra no momento. Assim se dá o fenômeno de aculturação:

Aculturação é o processo adaptativo de mudanças culturais e psicológicas, de natureza coletiva, que o migrante experimenta através de sua interação continua e direta com o contexto da cultura de acolhimento. Trata-se de um fenômeno psicossocial multidimensional que demonstra atitudes e comportamentos, consciente e insconscientemente. (BITTENS e JENNINGS-WINTERLE: 2015: 71)

Essas iniciativas não são passíveis de determinações teóricas estanques. Segundo Bittens e Jenninges-Winterle (2015), esse processo varia de sujeito para sujeito, uma vez que cada um tem um tempo próprio para se aculturar, um arcabouço próprio de referências culturais e linguísticas e, inclusive, níveis de estresse diferentes enquanto esse processo é desencadeado. Diante do fenômeno psicossocial da aculturação e da encruzilhada entre a LM e a LE, as autoras afirmam que as seguintes questões são colocadas pelo sujeito em seus encontros diários:

1. A minha identidade cultural tem valor suficiente para ser mantida?

2. Será que devo interagir com a sociedade dominante? (BITTENS e JENNINGS-WINTERLE, 2015: 71)

O modo como o sujeito lida com a experiência do refúgio e com o processo de aprendizagem da LE fornece informações importantes sobre a sociedade de acolhimento e as identidades; a depender do teor dessas informações, podemos rastrear a situação do sujeito e das outras gerações que se seguem, como seus filhos e netos.

Caso o sujeito considere que diante dessa situação de sobrevivência, preservar sua língua e suas raízes é a melhor providência a ser tomada com vistas a garantir o seu bem estar na experiência do refúgio, então, serão atribuídos certos valores a sua língua materna de modo que ela será, na medida do possível, preservada e transmitida para as próximas gerações. Caso, o sujeito considere que a melhor providência para superar a angústia de estar às margens da sociedade é adotar a língua oficial do país de refúgio, 
então a sua língua materna será imbuída de certos valores que provavelmente impossibilitarão a sua preservação e eventual transmissão para as próximas gerações.

De todo modo, é preciso propor algumas ressalvas com vistas a problematizar o Princípio da Valoração, apesar de sua inegável aplicabilidade quando discutimos a condição do refúgio. Esse princípio da Valoração é fundamentado na capacidade de deliberar sobre o que pode trazer, ou não, bem estar em uma situação de sobrevivência. Por meio do exercício da reflexão, o sujeito elabora uma resposta à detecção de desequilíbrios causados por comportamentos sociais que podem colocá-lo em risco:

Os expedientes culturais criados em resposta ao desequilíbrio visam restaurar o equilíbrio dos indivíduos do grupo. A contribuição dos sistemas econômicos e políticos, bem como, por exemplo, o desenvolvimento da medicina, são respostas a problemas funcionais encontrados no espaço social que demandam correção nos limites desse espaço para que não venham a comprometer a regulação da vida dos indivíduos pertencentes ao grupo. (DAMÁSIO, 2011: 356)

Há então, nos limites do Princípio, uma resposta a ser dada a uma questão dual: manter ou não manter; participar ou não participar; ficar ou partir. É justamente essa dualidade que nos traz desconforto teórico-metodológico quando nos debruçamos sobre contextos sociais críticos, tais como o refúgio. Por mais que o sujeito se veja diante de um dilema que lhe leva, aparentemente, a optar entre duas opções, consideramos que o sujeito estabelece uma rede de relações socioculturais que nem sempre o conduz necessariamente a escolher uma opção em detrimento de outra. Por exemplo, por mais que o sujeito rejeite a sua LM em favor da LE, será a LM que servirá de referência durante o processo de aprendizagem dessa LE. Além disso, há contextos multiculturais que fazem com que a realidade linguística de origem do sujeito do refúgio seja bilíngue ou ainda, plurilíngue. Logo, a possibilidade de valorar ou fazer uma escolha pautada na dualidade parece inviável quando o universo linguístico do sujeito não é dual.

Outra questão que nos leva a problematizar é a deliberação do sujeito em relação à língua a ser rejeitada. Quando supomos uma deliberação surge o questionamento sobre a possibilidade de deliberar efetivamente, de maneira autônoma.

Em contextos críticos como o contexto de um processo de aculturação de um sujeito que se encontra refugiado, há uma série de fatores que interferem na deliberação e na valoração atribuída a uma língua, por exemplo. É preciso reconhecer que nem sempre há liberdade de escolha para um sujeito que sofre humilhação social e que o sujeito não é uma entidade autônoma e isolada ao valorar o que irá assegurar, em princípio, o seu bem estar. 
Bittens e Jennings-Winterle (2015), ao discutir as dimensões dos processos de aculturação afirmam que a liberdade para deliberar nem sempre é verificável quando o grupo em questão é vítima de discriminação e é impedido de ter acesso à cidadania; preconceitos e pressões diversas podem impelir o sujeito a assumir uma determinada postura, que ignora, por exemplo, as suas inclinações afetivas em relação a uma língua, no que concerne à sua LM ou às suas LMs.

Esse modelo leva em consideração que o grupo minoritário tem a liberdade de escolher como vai aculturar-se. Como sabemos esse não é sempre o caso, mesmo entre brasileiros, que, apesar de geralmente imigrarem por questões econômicas, e não por conflitos bélicos, políticos ou intolerância de gênero, porventura sofrem preconceitos e pressões diversas que os impelem a uma ou outra postura de aculturação. (BITTENS e JENNINGESWINTERLE, 2015: 73)

Nessas circunstâncias, pode haver uma falta de autonomia ao valorar uma língua, o que tornaria o sujeito mais propenso a valorizar a língua que o grupo dominante traz em seu falar em detrimento da sua própria língua materna. Essas hipóteses nos levam a questionar $\mathrm{o}$ ato de deliberar autonomamente enquanto $\mathrm{o}$ Princípio de Valoração opera mesmo reconhecendo que o processo de valorar parece de fato servir ao propósito de manter o bem estar e a sobrevivência daqueles que se encontram socialmente vulneráveis.

Uma última questão resta ser discutida: se o sujeito é orientado por impulsos socioculturais homeostáticos, cabe indagar como é possível rastrear os valores atribuídos a referências linguísticas uma vez que elas, nesse contexto de discussão, não podem ser apreendidas concreta ou quantitativamente. Por essa razão, assumimos que a proposta de Krumm (2003) sobre retratos linguísticos pode contribuir de maneira enriquecedora na análise do Princípio da Valoração à luz de questões linguísticas no contexto do refúgio. 


\section{IV - Discussão e encaminhamentos metodológicos}

Revuz (2001: 220) afirma que "cada um tem uma história singular com a língua que fala". A autora, ao discutir sobre os processos de aprendizagem de LE e o embate que é travado entre LE e LM, observa que cada sujeito carrega uma narrativa de uso que está atrelada às suas línguas. Mais importante do que considerar o que essa narrativa nos conta é encontrar que método é capaz de apreender essa narrativa de modo que ela expresse os valores que a essa língua estão vinculados.

No caso da LM no contexto do refúgio, a narrativa de uso pode nos contar uma história de resistência, uma história que relembra momentos vividos no país de origem, uma história que evoca familiares de que não se tem mais notícia, uma história de trânsito e de partidas, uma história de conflitos e de dores, mas também de recomeços. Cada história singular que o sujeito tem com a LM revela particularidades da relação que ele mantém com suas heranças linguísticas e culturais. Do mesmo modo, à medida que o sujeito, na condição de refugiado, vive no país de refúgio, outra história surge: a história com a LE. Essa narrativa de uso também nos traz importantes informações sobre como esse sujeito sobrevive na sociedade de acolhimento e pode nos contar uma história de superação ou de resignação diante das dificuldades, do desamparo, da busca pela cidadania, da ansiedade ou da rejeição na sala de aula. As histórias são múltiplas, subjetivas e, muitas vezes, permanecem inacessíveis.

As dificuldades de compreender e acessar essas histórias linguísticas e os valores que nelas estão incutidos conduziram o linguista austríaco Hans-Jürgen Krumm (2003) a propor o que ele chama de Sprachenporträts (retratos linguísticos).

Com o objetivo de discutir a realidade linguística de sujeitos plurilíngues, Krumm (2003) desenvolveu o método de aplicar uma atividade lúdica e manual para apreender a relação que esses sujeitos estabelecem com as línguas que falam para, assim, rastrear os valores que são atribuídos a elas. Um método muito comum em pesquisas que assumem esse escopo de estudo é a realização de entrevistas. Essas entrevistas, geralmente, apresentam perguntas que são variações do seguinte questionamento matriz: que línguas esse sujeito realmente fala e quais as razões que ele tem para falar, ou não, determinada língua? 
Um problema que se verifica nesse modo de proceder à análise é que há muitas variáveis que podem interferir na resposta a ser dada de modo que certos valores atribuídos a uma língua podem escapar ao pesquisador. Pode-se, por exemplo, afirmar que uma determinada língua é frequentemente falada com vistas a causar uma determinada impressão de prestígio, quando na realidade, tal língua é raramente usada pelo entrevistado.

Os retratos linguísticos permitem desmascarar respeitosamente essas realidades de modo a questionar as respostas imediatas que são dadas nas entrevistas. Além disso, essa estratégia promove processos de conscientização linguística tanto por parte do entrevistado quando por parte de quem o entrevista.

\subsection{De cor em cor: métodos visuais a serviço da linguística}

Antes de procedermos a uma discussão mais pormenorizada sobre os retratos linguísticos propostos por Krumm (2001; 2003), cabe tecer algumas considerações sobre o método que ampara o uso dos retratos com a finalidade de obter informações linguísticas. Mais especificamente, referimo-nos ao embate entre LM e LE na identidade de um sujeito bilíngue ou multilíngue.

Lima-Hernandes e Ciocchi-Sassi (2015) discutem o conceito de comunidades multilíngues da seguinte forma:

Para compreender melhor esse novo enquadramento, poderíamos considerar esse novo enquadramento, poderíamos considerar esses espaços multiculturais como aquarelas em que comunidades culturalmente diversas convivem a meias paredes com outras comunidades muito diversas, inclusive na língua, sem que a divisão espacial seja capaz de recortar grupos e laços de identidade de modo simples. (LIMA-HERNANDES e CIOCCHI-SASSI, 2015: 105)

A partir do que as autoras afirmam, essas "aquarelas" que integram a experiência linguística de um sujeito multilíngue podem estar internalizadas de tal modo fluído e dinâmico que se torna dificultoso apreender os laços identitários atados entre ele e a língua. Por essa razão, há a necessidade de buscar métodos que sejam compatíveis com o propósito de realizar uma aproximação com esses laços e diferenciação das cores que compõem essas aquarelas.

Conforme Melo-Pfeifer e Simões (2017) afirmam, os métodos visuais consistem no emprego de desenhos, retratos, imagens e outras representações da mesma natureza para verificar a dimensão cognitiva, afetiva e social de fenômenos linguísticos. Além 
disso, trata-se de um procedimento que ainda não se encontra totalmente estabilizado em termos científicos e, ainda assim, viabiliza diferentes possibilidades de aplicação. E, apesar de diferentes possibilidades, é preciso reconhecer que todas elas estão focadas em projetar um multilinguismo que é vivenciado cotidianamente em um multilinguismo que é desenhado ou colorido.

Para as autoras, os métodos visuais consistem em uma alternativa desafiadora às tendências metodológicas que se restringem apenas ao discurso:

Com efeito, o recurso a métodos visuais desafia uma paisagem metodológica, epistemógica e heurística ainda marcada pela tendência "lingualista" (Block, 2014), que valoriza o texto e o discurso de entre todas as possíveis produções dos sujeitos, e coloca os investigadores diante do complexo semiótico que é o objeto visual, na sua multisemioticidade e multimodalidade, em que os elementos verbais poderão ter um lugar, mas que terá que ser sempre interpretado, julgado e relativizado no seu diálogo com os outros elementos. (MELO-PFEIFER e SIMÕES, 2017: 18)

Uma questão que precisa ser considerada é que os métodos visuais podem ser facilmente obliterados por reflexões excessivamente subjetivas do pesquisador. Por essa razão é recomendável que esses dados sejam combinados com elementos linguísticos. Por meio dessa combinação é possível acessar o estatuto das emoções e vivências presentes no processo de ensino-aprendizagem, sobretudo em contextos de vulnerabilidade social, como é o caso do refúgio, em que a humilhação que golpeia o sujeito atinge o âmbito do indizível. Angustiado, ele é conduzido a atribuir certos valores às suas referências culturais de modo que nem sempre é condizente com as suas inclinações identitárias.

A valorização dos métodos visuais, designadamente em DL (didática de línguas), tem acompanhado as discussões acerca do estatuto das emoções, das representações, da afetividade, do simbólico e do "indizível" no processo de ensino-aprendizagem de línguas, numa tentativa de acesso ao sujeito na sua integralidade e na sua complexidade, por vezes difícil de descrever, de se escrever e de se representar verbalmente. (MELO-PFEIFER e SIMÕES, 2017: 18)

Com vistas a otimizar o emprego dos métodos visuais, Coelho (2015) desenvolveu cinco categorias de análise que viabilizam o estudo combinado entre os dados recolhidos por meio desses métodos e dados linguísticos:

Tabela 1. Categorias de análise de Coelho (2015)

\begin{tabular}{|c|l|}
\hline \multicolumn{1}{|c|}{ Categorias } & \multicolumn{1}{|c|}{ Descrição das representações } \\
\hline CT1 - Língua como objeto afetivo & $\bullet$ Representa a a rãa \\
& $\begin{array}{l}\text { aluno/língua/cultura através de: } \\
\text {-desenho representativo do próprio ou de }\end{array}$ \\
\hline
\end{tabular}




\begin{tabular}{|l|l|}
\hline & $\begin{array}{l}\text { outrem; } \\
\text {-expressões faciais e corporais que } \\
\text { demonstram pela língua afeto ou não. }\end{array}$ \\
\hline $\begin{array}{l}\text { CT2 - Língua como objeto de ensino- } \\
\text { aprendizagem }\end{array}$ & $\begin{array}{l}\bullet \text { Representa a imagem da língua } \\
\text { associada ao ensino-aprendizagem, como, } \\
\text { por exemplo, o desenho de um livro ou de } \\
\text { uma sala de aula. }\end{array}$ \\
\hline $\begin{array}{l}\text { CT3 - Língua como instrumento de de } \\
\text { construção e afirmação de identidades } \\
\text { individuais e coletivas }\end{array}$ & $\begin{array}{l}\text {-Representa a relação língua/história de } \\
\text { um povo/cultura, no qual são apresentados } \\
\text { objetos, monumentos, bandeiras, entre } \\
\text { outros, os quais evidenciam a história e a } \\
\text { cultura, relacionadas com determinada } \\
\text { língua. }\end{array}$ \\
$\bullet \begin{array}{l}\bullet \text { Representa o poder de uma língua, } \\
\text { associado a uma imagem política. }\end{array}$ \\
\hline $\begin{array}{l}\text { CT4 - Língua como objeto de poder } \\
\text { CT5 - Língua como instrumento dém balões de fala ou palavras soltas } \\
\text { construção } \\
\text { interpessoais/integrupais. }\end{array}$ & $\begin{array}{l}\text { na língua, indicando a necessidade de } \\
\text { comunicação. }\end{array}$ \\
\hline
\end{tabular}

\subsection{A proposta de Krumm}

Os retratos linguísticos de Krumm $(2001 ; 2003)$ são fornecidos por meio de uma atividade aparentemente simples: para cada sujeito a ser entrevistado, são apresentadas silhuetas (Silhouetten) de um corpo impresso em um papel.

Imagem 1. Sugestão de silhueta proposta por Krumm (2003)

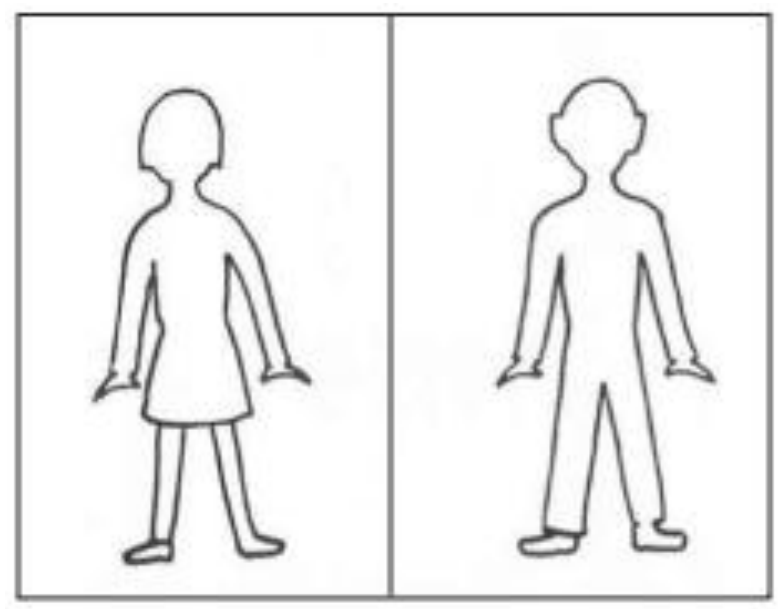

Nessa silhueta há apenas o contorno de um corpo sem expressão facial. O pesquisador que conduz essa atividade deverá instruir ao entrevistado que ele pense nas línguas que fazem parte do seu universo linguístico e preencha essa silhueta colorindo e 
projetando-as no papel. Após finalizar a tarefa, o sujeito deverá apresentar na forma de depoimento, oral ou escrito, o processo que o levou a representar tais línguas de determinado modo e explicitar, na medida do possível, a lógica por detrás de uma biografia linguística. Tanto a imagem colorida quanto o depoimento devem ser analisados no processo de desvendamento das histórias e dos valores em questão.

Para Krumm (2003) essa atividade pode ser proposta tanto a adultos quanto a crianças e a adolescentes, não havendo aparentemente restrição de faixa etária, de origem social ou cultural e de gênero. $\mathrm{O}$ autor afirma que tanto adultos quanto crianças podem ser receptivos a essa proposta, havendo, talvez, uma certa hesitação por parte dos primeiros no engajamento dessa tarefa. Mesmo assim, Krumm (2003) afirma que ambos os grupos costumam se sentir motivados a expressar suas histórias com as línguas representadas. Em suas palavras, "até adultos apresentam entusiasmo ao descrever seus retratos" (KRUMM, 2003: 45) ${ }^{4}$.

Pode-se dizer que a proposta dessa atividade visa à superação das limitações dos roteiros de entrevista pré-estruturados; no entanto, é preciso reconhecer que é necessário que o pesquisador siga certa conduta de modo a não interferir no retrato linguístico e de modo a orientar o entrevistado para fazer dessa atividade uma fonte confiável de informações linguísticas. Não se trata, então, de descartar as entrevistas préestruturadas, uma vez que os depoimentos fazem parte da análise. Trata-se de buscar meios que agreguem informações consistentes aos dados extraídos dessas entrevistas. Desse modo, é possível também promover uma compreensão mais pormenorizada sobre como o Princípio da Valoração opera quando o sujeito expressa o vínculo que tem com as línguas representadas no retrato.

Krumm (2003) descreve como o entrevistador deve proceder ao propor a feitura de um retrato linguístico. Em geral, a forma como o sujeito deverá colorir a imagem e distribuir as suas línguas é livre. O entrevistador só precisa ser claro quanto ao propósito da atividade: o sujeito deve refletir sobre as línguas que compõem o seu universo linguístico e situá-las no corpo representado na silhueta.

\footnotetext{
4"Den Einstieg in sprachenbiographisches Erzählen bildet in der Regel ein Sprachenporträt, beidem die eigenen Sprachen mit je verschiedenen Farben in Silhouetten hineingemalt warden (KRUMM, 2001), eine Aktivität, die nicht nur Kinder, sondern - eventuell nach kurzem Zögern - auch Erwachsene mit grossem Eifer ausführen und die in der Regel dazu führt, dass fast alle ihr Porträt beschriften bzw. etwas dazu erzählen wollen"
} 
O modo de interpelar deve ser feito vagamente, mas com o propósito definido: se você pudesse preencher esse retrato com as línguas que conhece, como você o faria? Outras perguntas são aceitáveis, desde que o cerne da mensagem seja esse e desde que elas sejam feitas em uma língua que o sujeito compreende, seja a sua língua materna, seja a língua do país onde reside. É importante que o depoimento também seja feito na língua em que o sujeito foi interpelado; obviamente, é importante que o entrevistado seja linguisticamente competente para articular um depoimento e para compreender as tarefas dadas.

As possibilidades de representação são muito ricas e variadas; por isso, é importante que o retrato não seja recolhido pelo pesquisador sem que o entrevistado tenha antes a oportunidade de verbalizar o que o motivou a colorir e a situar de tal modo as línguas representadas: "Os retratos linguísticos devem ser divulgados ("publicados”), eles não devem ser simplesmente deixados de lado ou recolhidos" (KRUMM, 2003: $111)^{5}$.

Krumm (2003) ainda afirma que o pesquisador ao conduzir a atividade deve tentar interferir o mínimo possível enquanto os sujeitos confeccionam os retratos. Além disso, nada deve ser comentado sobre o quão bem deve-se falar uma língua para que ela seja retratada no desenho; as orientações devem ser relativamente vagas. É importante que os sujeitos expressem suas percepções sobre as "suas línguas" e não se sintam impedidos por meio de diretrizes normativas.

Assim, as atribuições positivas e negativas reservadas ao acervo cultural vinculado a uma língua são evidenciadas na própria voz do falante que narra ou descreve o retrato linguístico em questão. Isso decorre da dinâmica entre a representação das línguas, as cores escolhidas para representá-las e o que chamaremos, nessa ocasião, de índices de corporeidade que transmitem um tipo de relação simbólica entre o sujeito e as línguas que ele fala considerando as referências culturais indissociavelmente vinculadas a elas.

Os exemplos a seguir extraídos de depoimentos da pesquisa de Krumm (2001: 111) acerca de retratos linguísticos feitos por sujeitos multilíngues residentes em países de língua alemã - língua que figura como língua uma das línguas maternas (no caso dos depoimentos 1 E 2) e língua estrangeira (no caso dos depoimentos 3 e 4) - demonstram como a supracitada dinâmica pode ser apreendida por meio da proposta dos retratos

\footnotetext{
5 "Die Spracheporträts müssen "veröffentlicht", sie dürfen nicht einfach weggelegt oder eingesammelt"
} 
linguísticos. Esses depoimentos foram fornecidos pelos entrevistados originalmente em alemão, mas para essa ocasião apresentaremos uma tradução livre deles. A versão traduzida integralmente do artigo encontra-se nos Anexos:

Tabela 2. Depoimentos de Krumm (2003)

(1) O inglês está na minha cabeça, porque ele é divertido. O espanhol está no meu corpo porque eu gosto muito da Espanha. Para mim o alemão está nas minhas mãos, porque eu escrevo muito. O italiano está nas minhas pernas porque eu já fui muitas vezes para lá ${ }^{6}$.

(2) Em mim o inglês está na cabeça, porque com essa língua eu tenho que pensar antes de falar. $\mathrm{O}$ alemão está nos braços, porque ele é a minha língua materna e por isso é muito fácil. O italiano está na minha barriga, porque eu não consigo falar quase nada ${ }^{7}$.

(3) O meu coração é húngaro. As partes mais importantes do meu corpo são húngaras. A minha barriga é italiana, porque eu gosto de comer comida italiana. Minhas pernas são alemãs, porque eu vivo em uma região onde se fala alemão ${ }^{8}$.

(4) Inglês tem a cor verde, porque lá sempre chove. Árabe tem a cor marrom, porque os países árabes têm muitos desertos. Alemão tem a cor preta, porque alemão é difícil. Persa tem a cor azul, porque lá tem um céu bonito 9 .

(5) Para mim o Yoruba está no corpo, porque o corpo não consegue ouvir e eu não consigo entender muito bem Yoruba. $\mathrm{O}$ inglês está para mim na cabeça, porque eu às vezes tenho que me concentrar muito para memorizar palavras. $\mathrm{O}$ francês está para mim nas pernas, porque ele (o francês) fica muito longe de mim e é difícil de aprender certo apesar de eu desejar isso. E para ir longe, é preciso ter pernas ${ }^{10}$.

\footnotetext{
6 "English ist bei mir im Kopf, weil es mir Spaß macht. Spanisch ist bei mir im Körper weil ich Spanien sehr mag. Bei mir ist Deutsch in den Händen, weil ich sehr viel schreibe. Italienisch ist in den Beinen, weil ich dort schon oft war" (KRUMM, 2001: 89)

7 "English ist bei mir im Kopf, weil ich bei dieser Sprache etwas nachdenken muss. Deutsch ist bei mir in den Armen, weil das meine Muttersprache ist um daher sehr leicht ist. Italienisch ist bei mi rim Bauch, weil ich es fast nicht kann..." (KRUMM, 2001: 89)

8 "Mein Herz ist ungarisch. Die wichtigsten Teile meines Körpers sind ungarisch. Mein Bauch ist Italienisch, weil ich gernen Italienisch esse. Meine Beine sind Deutsch, weil ich im deutschen Sprachgebiet lebe." (KRUMM, 2001: 89)

9 "Englisch hat grüne Farbe, weil dort immer es regnet. Arabisch hat braune Farbe, weil arabische Länder viele Wüsten haben. Deutsch hat schwarze Farbe, weil Deutsch schwer ist. Persisch hat blaue Farbe, weil dort schöne Himmel hat." (KRUMM, 2001: 75)

10 "Yoruba ist bei mir im Körper, weil der Körper nicht hören kann und ich kann Yoruba nicht so gut verstehen. Englisch ist bei mir im Kopf, weil ich mich manchmal ziemlich konzentrieren muss um mir Vokabeln zu merken. Französisch ist bei mir in den Beinen, weil es für mich sehr fern 1 iegt es richtig zu lernen obwohl das mein Wunsch ist. Und um in die Ferne zu gehen muss man Beine haben." (KRUMM, 2003: 111)
} 
(6) Eu colori de acordo com o meu sentimento. Eu não colori de acordo com a minha capacidade de falar. ${ }^{11}$

No caso do depoimento número (1), o entrevistado parece descrever o seu retrato à luz de suas preferências e habilidades. Para ele, filho de espanhóis e italianos e residente na Alemanha, o inglês é considerado um idioma divertido; o espanhol presente em seu cotidiano e positivamente valorado ocupa quase todo o seu corpo. $\mathrm{O}$ alemão é uma língua aparentemente instrumental e cujo domínio da competência de escrita parece ser avançado. Por fim, o italiano, relativamente distante do universo linguístico foi situado nas pernas, representação que parece estar atrelada com o deslocamento constante para esse país, provavelmente porque há familiares que ainda residem lá.

O sujeito do depoimento (2), filho de italianos e nascido na Alemanha, a LM foi retratada nos braços, provavelmente por ser acessível e facilmente articulada no seu cotidiano. O inglês, aprendido como LE, foi localizado na cabeça por que é considerada uma língua em que ele é capaz de se expressar, mas aparentemente não de maneira espontânea. O italiano, língua materna dos pais foi situada na barriga o que nos conduz à conclusão de que isso retrata certo distanciamento do sujeito em relação a essa língua ou ainda, que essa língua para ele não é tão funcional quanto o alemão (localizado nos braços) e o inglês (localizado na cabeça).

Para o entrevistado do depoimento (3), húngaro, descendente de italianos e residente em um país de língua alemã, os índices de corporeidade mais importantes estão atrelados ao húngaro, sua língua materna, como o coração por exemplo. As outras duas línguas que compõem a sua atual realidade linguística, o alemão e o inglês, ficaram respectivamente distribuídas nas pernas de modo a simbolizar a sua relação com o seu atual país de residência e na barriga, de modo a retratar seus hábitos alimentares.

Por fim, o depoimento (4) demonstra um processo de representação um pouco diferente dos outros, pois parece que o entrevistado, iraniano, porém residente na Alemanha, se orientou mais pela relação língua-cor do que pelas referências corporais. Seu conhecimento de mundo acerca do espaço geográfico onde se falam as línguas que compõem o seu universo linguístico, bem como as dificuldades vinculadas à aprendizagem da LE, que para ele é o alemão, ampararam a sua reflexão linguística.

\footnotetext{
11 "Ich habe nach meinem Gefühl gemalt. Ich habe nicht nach meinem Können gemalt." (KRUMM, 2003:
} 112) 
Vale ressaltar, que o alemão foi considerado um idioma muito difícil e por isso, colorido em preto. Já as suas línguas maternas, o persa e o árabe, foram representados com indícios de afetividade e de modo a evocar aspectos da geografia do lugar onde se fala essas línguas.

É importante salientar que a investigação por meio dos retratos linguísticos pode viabilizar também a investigação de línguas de herança. Por exemplo, o falante pode representar no retrato linguístico uma língua que ele não é linguisticamente competente, mas que por alguma razão ele declara ter um vínculo afetivo com ela. Jennings-Winterle e Lima-Hernandes (2015: 265) assim definem as línguas de herança: "Língua aprendida no seio familiar que não é a língua majoritária no país ou comunidade na qual tal família reside (como por exemplo em algumas comunidades indígenas e aborígenes".

O corpus de Krumm (2003) nos fornece dados que amparam a constatação de que os retratos linguísticos permitem o rastreamento de línguas de herança que possuem importância na identidade do sujeito. No depoimento (5) o falante, residente na Alemanha, alega que o Yoruba é uma língua que ela não é linguisticamente competente, por não conseguir falar e entender. Mesmo assim, essa língua ocupa um lugar no seu retrato, o que nos leva a concluir que ela compõe a realidade linguística do sujeito e também atua com um elemento integrador da sua identidade com a comunidade origem dos seus familiares.

Outro falante, no depoimento (6) alega que o que o orientou em seu retrato linguístico não foi a sua capacidade de falar, mas sim, o seu "sentimento". Esses dados são de suma importância, pois evidenciam que a necessidade de levar em consideração a dimensão afetiva do sujeito em discussões que visam à análise de certas realidades linguísticas. Discutir afetos e línguas não é necessariamente uma proposta desconexa com pode parecer em princípio e, a depender do contexto de análise, é de suma importância.

No concerne especificamente às categorias de análise de corpus, parece-nos que a proposta de Krumm (2003) atende aos propósitos das categorias 2, 3 e 4 que foram descritas por Coelho (2005): CT2 - língua como objeito de ensino-aprendizagem; CT3 - língua como instrumento de construção e afirmação de identidades individuais e coletivas e CT4 - língua como objeto de poder.

A proposta de Krumm (2001) foi empregada em outros estudos com vistas a rastrear a relação do sujeito em contextos de migração com as línguas que compõem o 
seu universo linguístico e de modo a revelar particularidades desses contextos que podem levá-lo a desvalorar a sua LM em função da LE ou ainda, em valorar a sua LM em detrimento da LE. Atribuições positivas e negativas às línguas podem ser retratadas e descritas por meio desse método.

Algumas recorrências são verificáveis nos retratos linguísticos, apesar do repertório linguístico e cultural particular de cada sujeito. Krumm (2003) observou que as línguas que são valoradas come um enfoque prático no cotidiano das pessoas costumam ser representadas na cabeça, não mãos e nas pernas; as línguas maternas costumam ser representadas em vermelho, na região do coração ou na cabeça. Línguas que são importantes, em termos afetivos, para o sujeito, mas não são faladas por ele, costumam ser representadas na barriga.

É preciso sempre ter cautela quando lidamos com quaisquer generalizações, mas, de acordo com o autor, esses dados por ser recorrentes revelam que certas relações simbólicas são representadas por meio dos mesmos índices de corporeidade pelos falantes que falam mais de uma língua, uma vez que "quase metade de todos os retratos linguísticos apresentam o vermelho como a cor da língua materna ou situam a língua materna onde o coração se localiza, que quase todas as línguas situadas na cabeça, nas mãos e nas pernas costumam exercer uma função prática muito importante" ${ }^{\text {"12 }}$ (KRUMM, 2003: 113).

Essas constatações, apesar da relevância, precisam ser ressalvada: supomos que tais recorrências podem não ser verificadas em retratos linguísticos produzidos por falantes que apresentam um outro repertório cultural ou que são oriundos de países não ocidentais ou ainda que residem, no momento, em países não ocidentais. Para uns, por exemplo, o vermelho pode não a cor da língua materna.

Os retratos linguísticos foram empregados no estudo de Seals (2017) que partiu do pressuposto de que atribuições negativas a uma língua indicam que o sujeito quer tomar distância das referências culturais e identitárias vinculadas a ela. Com base nesse pressuposto, ela desenvolveu um estudo aliando a análise dos retratos linguísticos e dos

\footnotetext{
12 "Dass Valon seinen Körper von oben bis unten in zwei Hälften (blau - Deutsch, rot - Albanisch) teilt (vgl. Krumm, 2001: 11), dass nahezu bei der Hälfte aller Sprachenporträts die Mutterfarbe in roter Farbe als Herz oder zumindest dort, wo das Herz sitzt, eingezeichnet ist, dass die Sprachen in Kopf, Händen und Beinen für die Kinder eine so wichtige Rolle spielen, sollte im Unterricht zur Sprache kommen, z.B. durch Sprachwink-Übungen” (KRUMM, 2003: 113).
} 
depoimentos a um breve levantamento quantitativo sobre as línguas que declaradamente são faladas pelo sujeito.

A autora engajou-se em entrevistar famílias de imigrantes ucranianos residentes nos Estados Unidos com o objetivo de registrar quais línguas eram faladas por eles. Nesse contexto, o ucraniano corresponde à LM e o inglês à LE. O resultado obtido mostrou que para essas famílias, suas línguas maternas eram praticamente irrelevantes e estavam quase que em desuso, sobretudo entre as crianças e os mais jovens.

No entanto, ao aplicar a proposta dos retratos linguísticos, a pesquisadora pôde verificar que ao retratarem as LMs, os entrevistados demonstraram um considerável enfoque sobre elas e expressaram um forte vínculo afetivo com a língua. Essa LM acaba por promover uma sensação de pertencimento a uma comunidade, uma vez que em situações de migração crítica, o pertencimento e participação na vida comunitária do país de acolhimento nem sempre são assegurados.

Essas constatações nos conduzem a questionar em que medida essas línguas realmente encontravam-se em desuso na ocasião em que essas famílias foram entrevistadas. Para Seals (2017: 15), a disparidade entre os dados reunidos quantitativamente e as informações extraídas dos retratos linguísticos indicam que é preciso cautela para não associar uso linguístico a identificação linguística. Por mais que o sujeito rejeite a sua LM ou declare que não é mais linguisticamente competente em sua LM, a valoração linguística verificável no retrato pode indicar o contrário:

Isso cria uma distinção muito importante que não é frequentemente encontrada nas pesquisas sobre aquisição de língua e multilinguismo: o uso linguístico não influencia diretamente e não reflete diretamente a auto-identificação linguística do sujeito ${ }^{13}$. (SEALS, 2017: 15).

As atribuições negativas reservadas a uma LM no estudo de Seals (2007) resultam de um contexto social que força o sujeito a desvalorar a sua LM e o impele a rejeitar as referências culturais de seu país de origem. Marginalizado nesse novo espaço social, parece claro que as fronteiras geográficas que foram ultrapassadas por ele não condizem com as fronteiras sociais e culturais que persistem e impedem o seu acesso à cidadania e sustentam uma situação de humilhação social.

\footnotetext{
13 "This even creates a very important distinction not often found in research on language acquisition and multilingualism: that language use does not directly influence, and is not directly reflective of linguistic self-identification"
} 
A análise de Seals constatou que essas circunstâncias conduzem o sujeito migrante a assumir perante o outro que a sua LM encontra-se em processo de desuso em todas as dimensões de seu cotidiano, seja no ambiente familiar, ou não. No entanto, essa declaração não necessariamente reflete o valor que ele realmente atribui à sua língua, uma vez que as atitudes de rejeição da LM e de valorização da LE foram desmascaradas nos retratos linguísticos. Parece que o ato de declarar o desuso linguístico da LM coaduna com a necessidade de se proteger diante do outro em uma situação crítica que exige que o sujeito se encaixe em um padrão. E por mais que ele afirme o contrário, a LM - ou até mesmo uma LH - permanece como um fio condutor que o leva até as suas raízes.

\subsection{Grupo a ser retratado: os colombianos}

Quando o tema refúgio é abordado, os países que figuram no topo das estatísticas acabam ganhando maior visibilidade, bem como a situação histórica e política que conforma a necessidade que a população revela na solicitação de refúgio a outro país. Atualmente, a Venezuela por ter apresentado o maior número de solicitações de refúgio em 2017 tem sido constantemente abordada pela mídia. No entanto, como afirmamos anteriormente, é preciso reconhecer a dimensão humana que não é acessível quando nos debruçamos inadvertidamente sobre os dados numéricos. Nesse sentido, a proposição de quaisquer discussões sobre o tema refúgio não deve se restringir apenas aos países que se encontram em evidência nas pesquisas quantitativas.

Em 2014, a ACNUR (2014) contabilizou a seguinte distribuição de nacionalidades entre os grupos que solicitaram refúgio naquele ano e tiveram suas solicitações atendidas: o maior grupo, formado por sírios equivalia a 1.524 pessoas. Depois dos sírios, havia, naquela ocasião, o grupo dos colombianos (1.218 pessoas), dos angolanos (1.076 pessoas), dos congoleses (784 pessoas), dos libaneses (391 pessoas), dos libérios (258 pessoas), dos palestinos (263 pessoas), dos iraquianos (229 pessoas), dos bolivianos (145 pessoas) e, por fim, dos leoneses (137 pessoas). Já, no triênio de 2015 a 2017, os colombianos não figuraram entre os 10 maiores grupos de solicitantes de refúgio no Brasil.

Em princípio, cabe indagar o porquê de os colombianos não terem sido contabilizados com expressividade nas estatísticas referentes ao refúgio no Brasil no 
último biênio. Esse fenômeno pode ser explicado por três razões principais (ACNUR, 2014: 2):

1. Os avanços da negociação de paz entre o governo da Colômbia e as FARCs, o que diminuiu, em certa medida, a onda de violência no país;

2. A adesão da Colômbia ao Acordo de Residência do Mercosul, facilitando o trânsito de pessoas dos países que integram a América do Sul. Esse acordo facilitou a obtenção de residência temporária no Brasil por um período de dois anos, que, posteriormente, poderia ser convertida em residência permanente, sem precisar efetuar uma solicitação de refúgio.

3. A postura do governo brasileiro em facilitar a entrada de quem quisesse solicitar refúgio em decorrência do conflito sírio por meio da emissão de um visto de turista válido por 90 dias.

A quase ausência dos colombianos nas estatísticas não significa, portanto, que a situação política e social na Colômbia superou por completo a violência generalizada que vitimiza a população. Trata-se apenas das consequências de um acordo diplomático entre Brasil e Colômbia aliado a circunstâncias da própria conjuntura social e política da Colômbia. Segundo o CONARE (2016) ${ }^{14}$, há mais de 1.100 colombianos que se encontram refugiados no Brasil. No entanto, Thuller (2016), coordenadora do Programa de Atendimento a Refugiados da Cáritas, no Rio de Janeiro, afirma que é possível que esse número seja ainda maior:

O que temos verificado é a redução do número de novas solicitações de vistos de refugiado, dado pelo acordo de residência do Mercosul. Hoje muitos colombianos ainda vêm para o Brasil, mas ao invés de solicitar refúgio dão entrada no pedido de solicitação por este acordo. $^{15}$

$\mathrm{Na}$ condição de refugiados, os colombianos assumem, aos olhos do brasileiros, alguns estereótipos que se estabilizaram no imaginário social da população, quais sejam, o de pessoas identitariamente ligadas à violência e ao narcotráfico. Esses estereótipos não contemplam a diversidade populacional, linguística e cultural que se verifica na Colômbia, especialmente porque os traços são heterogêneos desde a concepção, já que há miscigenação entre brancos, negros e indígenas. Essa heterogeneidade também tem representação na inegável herança linguístico-cultural:

\footnotetext{
14 Disponível em: http://pt.slideshare.net/justicagovbr/refgio-no-brasil-51820929. Acesso em: 10 jan. 2016.

${ }^{15}$ Disponível em: http://br.rfi.fr/brasil/20160507-conflito-continua-levanto-colombianos-se-refugiaremno-brasil. Acesso em: 12 abr. 2018.
} 
É estranho como alguns estereótipos se fixam na cabeça das pessoas. Se, para muitos, o Vietnã ainda é sinônimo de uma guerra que já terminou há mais de quarenta anos, a Colômbia, na cabeça de muita gente, remete apenas ao bandido Pablo Escobar, morto há mais de vinte, ao narcotráfico e à violência. Sim, o narcotráfico é importante para se compreender os colombianos, mas de forma alguma o país e sua população se reduzem a isso. (TRAUMANN, 2018: 9)

Os conflitos que marcaram e ainda marcam a história da Colômbia consubstanciam-se num quadro de violência que já obrigou mais de 5,7 milhões de colombianos (ACNUR, 2017) a cruzarem fronteiras em busca de segurança e melhores condições de vida. Para compreender a raiz desses conflitos, a seguir organizamos algumas informações.

\subsubsection{Situação sócio-histórica}

Em 1953, a Colômbia encontrava-se em uma situação de penúria social e exploração, encabeçada por uma minoria abastada contra a população que vivia nos campos. Enquanto a população, sobretudo os camponeses, tentava se articular por meio de pequenos núcleos de resistência formados por guerrilheiros, as medidas de repressão eram ferozes e implacáveis.

Nos entremeios de um conflito desigual que censurava os direitos de expressão do sujeito, que era punido por reivindicar direitos, dirigentes políticos se revezavam em jogos de poder. O efeito disso foi o golpe de Estado desferido pelo general Gustavo Rojas Pinilla.

Ao lançar um véu de suposta pacificação sobre a caótica ordem pública, o governo instituído, na ocasião, implantara um "Plano de Paz" que serviu para acobertar uma onda de violência generalizada a todas as iniciativas que representavam qualquer tipo de oposição:

Foi nessa época que o general Gustavo Rojas Pinilla deu um golpe de estado (com o apoio de liberais e conservadores que tempo depois se uniriam novamente para tirá-lo do poder) e implantou a paz através da anistia. Os guerrilheiros liberais e conservadores que entregaram as armas foram assassinados quando não aceitaram trabalhar para a polícia ou as forças de segurança. As forças camponesas de autodefesa organizadas por Marulanda mantiveram-se alerta, sem adotarem o "plano de paz", e isso salvou a vida deles e de muitos camponeses. Assim, a violência começou outra vez com ferocidade inaudita, mas oficialmente reinava a paz. (BARRENCHE, 2014: 61)

Não se sabe ao certo quantas foram as vítimas mortas nesse período, denominado "La Violencia". Barrenche (2014) afirma que o valor estimado de mortos soma um total de 400.000 até 15 milhões de mortos. Devido ao estratégico descuido dos 
governos totalitários em conservar certos registros no caos burocrático, talvez nunca saibamos exatamente quantos sofreram as mazelas desse governo. Por mais que haja certas intuições sobre a dimensão de um acontecimento, lamentavelmente, há certos rastros que não se pode reconstruir com exatidão.

Paralelamente, ao mesmo passo em que as empreitadas militares de repressão eram levadas a cabo, surge, em 1964, as Forças Armadas Revolucionárias da Colômbia, doravante, as FARC. O estopim que consolidou a formação desse grupo guerrilheiro foi a invasão dos militares a um pequeno núcleo formado por 80 famílias que residia na região de Marquetalia:

No dia 27 de maio de 1964 é lançada uma operação contra as famílias assentadas na região. Trata-se de uma operação de 16.000 homens com armamento sofisticado, apoio aéreo e assessoria norte-americana. $\mathrm{O}$ combate é contra 50 homens armados que fugiram para as montanhas com suas famílias, umas 150 pessoas no total, mais haveres e animais. Fala-se em bombas de NAPALM que foram jogadas no local. (BARRENCHE, 2014: 62)

Diante dessa operação militar, essas famílias não tiveram outra opção que não fosse o deslocamento de forças para as montanhas que se localizavam na região. A ideia era se reorganizar e formar uma frente de resistência que passaria a assumir anseios de politização e não apenas de reivindicação territorial. É justamente essa frente de resistência que se autodenominou as FARC e que paulatinamente foi se fortificando enquanto movimento político e social de modo a se consolidar como um poder paralelo que concorria com o Estado.

As FARC expõem as bandeiras de um novo movimento político, a Unión Patriótica (UP) que, em campanha de só seis meses, consegue levar vários de seus líderes ao Parlamento, às Prefeituras, aos Conselhos Municipais e às Câmaras Estaduais, com um cabedal de votos de aproximadamente 360.000 votantes. Durante a década seguinte foram assassinados mais de 4.000 dirigentes da UP de forma seletiva ou através de massacres, incluindo Jaramillo, o candidato à presidência, fato que eliminou $\mathrm{o}$ incipiente movimento político. (BARRENCHE, 2014: 61)

Por se constituir como um poder paralelo, as represálias organizadas e empreendidas pelo Estado foram enfrentadas pelo movimento por meio de ameaças, massacres e violência generalizada, o qual vitimou não apenas os seus oponentes políticos, mas também os civis. Para manter a integridade e financiamento do movimento uma associação entre as FARC e o narcotráfico: o grupo cobrava impostos dos traficantes em troca de colaboração. Esses impostos serviram para financiar o armamento e as empreitadas do grupo, que passou a ser combatido não apenas pelos militares, mas também pelos paramilitares. Os paramilitares eram milícias sustentadas pelos latifundiários, que se sentiam ameaçados pela atuação política dos guerrilheiros, 
assim intimidando por meio da violência a população com vistas a eliminar aqueles que eventualmente colaborassem com as FARC.

Nesse contexto de violência generalizada, mesmo após a instituição de um estado republicano, a população colombiana permaneceu refém. Apesar dos modestos progressos, apontados pela Human Rights Watch (2018), orientados pelo restabelecimento e defesa dos direitos humanos, os colombianos ainda enfrentam as consequências de décadas de confrontos entre os guerrilheiros, os militares, os paramilitares e os narcotraficantes.

\subsubsection{Línguas da Colômbia}

A Colômbia, país de colonização espanhola, tem como língua oficial majoritária o espanhol e mais de outras 60 línguas registradas que coexistem no mapa linguístico do país. Não nos ateremos, nessa ocasião, a apresentar de maneira pormenorizada as ricas particularidades de linguísticas de cada uma delas, uma vez que o escopo do presente estudo consiste em investigar os valores que são atribuídos a essas línguas em contextos de dominação. No entanto, consideramos importante descrever brevemente a diversidade linguística que se verifica na Colômbia.

Soares (2001: 10) afirma que a Colômbia é um "país em que existem sessenta e cinco línguas indígenas, duas línguas crioulas e onde o castelhano real se manifesta através de um grande número de variantes regionais relativamente distantes entre si”. Logo, o tecido linguístico que se estende sobre os $1.138 .914 \mathrm{~km}^{2}$ das terras colombianas é muito diverso e sua trama é composta tanto por influências indígenas quanto africanas. Por debaixo desse rico tecido linguístico há aproximadamente 48.747 .632 habitantes (TRAUMANN, 2018)

No que concerne às 65 línguas indígenas, Landaburu (2001) constata que elas são faladas por aproximadamente 500 mil pessoas em 22 dos 32 departamentos do território colombiano. Essas línguas foram reconhecidas pela Constituição Colombiana de 1991 como línguas oficiais, juntamente com o espanhol, nos respectivos departamentos em que elas são faladas.

Sesenta y cinco lenguas indígenas amerindias extremadamente diversas, habladas por unas quinientas mil personas en 22 de los 32 departamentos del territorio colombiano. Tanto estas lenguas como las dos criollas que acabamos de mencionar fueron reconocidas por la Constitución política de Colombia de 1991 como oficiales con el español en los territorios en las que se hablan (LANDABURU, 2001: 12) 
As línguas de origem indígena que são faladas na Colômbia pertencem a 13 famílias linguísticas, a saber: Arawak, Caribe, Tupi-Guarani, Quechua, Chibcha, Chocó, Guahibo, Sáliba, Macú, Huitoto, Bora, Tucano e Barbacoa. Há também 8 línguas que, por não terem sido catalogadas como pertencentes a essas famílias foram denominadas "línguas únicas” por Landaburu (2001: 12):

\begin{abstract}
Se puede en este momento reagrupar las sesenta y cinco lenguas indoamericanas presentes en el territorio colombiano en trece familias lingüísticas diferentes, a las cuales hay que añadir ocho lenguas aisladas no reagrupadas en este momento con otras, lo cual nos da veintiún estirpes diferentes. Algunas de estas estirpes tienen una presencia continental importante como las grandes familias Arawak (8 lenguas en Colombia), Caribe (2 lenguas), Tupi-Guaraní (2 lenguas), Quechua (2 lenguas) o la gran familia Chibcha (7 lenguas) de probable procedencia centroamericana ; otras son de ámbito más regional como las familias Chocó (2 lenguas), Guahibo (4 lenguas), Sáliba (2 lenguas), Macú (3 lenguas), Huitoto (3 lenguas), Bora (2 lenguas),Tucano (18 lenguas) y Barbacoa (2 lenguas), solamente presentes en el noroeste de Suramérica, en Colombia y en sus vecinos. Las ocho estirpes de lenguas únicas son las siguientes: andoque, cofan, kamëntsá, páez, tinigua, yagua, yaruro, ticuna (esta última también presente en Brasil)
\end{abstract}

Já no que concerne às línguas de origem africana, Landaburu (2001) registra o crioulo de San Basilio de Palenque, também chamado palenquero, com cerca de três mil falantes e o crioulo das Ilhas de San Andrés e Providencia com cerca de trinta mil falantes. A origem dessas duas línguas remete ao contexto da escravidão na América de colonização espanhola e, assim como as línguas de origem indígena, foram reconhecidas pela Constituição Colombiana de 1991 como oficiais nos respectivos departamentos onde elas são faladas:

Fueron creadas por esclavos de origen etnolingüística africana diversa (más netamente bantú en el caso del criollo de Palenque), en la época de la trata y de la esclavitud impuesta por los europeos en los siglos de la colonia. El criollo de San Basilio o "palenquero" nace en un contexto hispánico y el mayor número de sus raíces léxicas proviene del castellano constituyéndose así aparentemente en el único criollo de base hispánica del continente americano. El criollo de San Andrés y Providencia nace en un contexto de habla inglesa (migraciones desde la Jamáica) y su fondo léxico es mayoritariamente inglés.

O palenquero, segundo Petter (2011) é o único crioulo de base espanhola falado na América do Sul. A cidade onde se registra essa língua foi formada por escravos de origem banta que fugiram dos latifúndios e se reuniram em núcleos de resistência denominados palenques. O crioulo de San Andrés e Providencia foi trazido por migrantes da Jamaica, e por isso sua origem é de base inglesa.

Levando-se em conta a diversidade linguística do país, consideramos que os retratos linguísticos coletados no contexto do refúgio no Brasil fornecerão ricas 
informações tanto sobre a identidade linguístico-cultural do sujeito quanto sobre a relação estabelecida entre esses sujeitos, LM e LE.

\subsection{A busca pelos dados}

O modo de realizar a coleta dos dados se baseou tanto na proposta de Krumm (2001) quanto na leitura de Seals (2017) sobre os retratos linguísticos.

Orientamos-nos pelo propósito de capturar o universo linguístico de sujeitos multilíngues que se encontram refugiados no Brasil. E para atingir tal propósito, os procedimentos metodológicos empregados foram subdivididos em três etapas.

Primeiramente, os participantes da pesquisa foram interpelados sobre quais línguas são conhecidas e faladas por eles, não havendo nenhuma especificidade sobre o quanto esses sujeitos são competentes nessas línguas. No cartão a ser assinaldo, constavam as seguintes perguntas:

1. Fala/conhece mais de uma língua?

2. Em caso afirmativo, especifique:

Depois, lhes foi apresentada a proposta dos retratos linguísticos por meio da seguinte tarefa:

1. Você deve colorir essa imagem mostrando as línguas que fala ou que conhece.

Para que eles pudessem finalizar os seus retratos, foram oferecidos lápis de cor e giz de cera. Optamos por apresentar as silhuetas sem marcas de gênero ou vestimentas, somente com o contorno do corpo. 
Imagem 2. Imagem usada nos retratos linguísticos

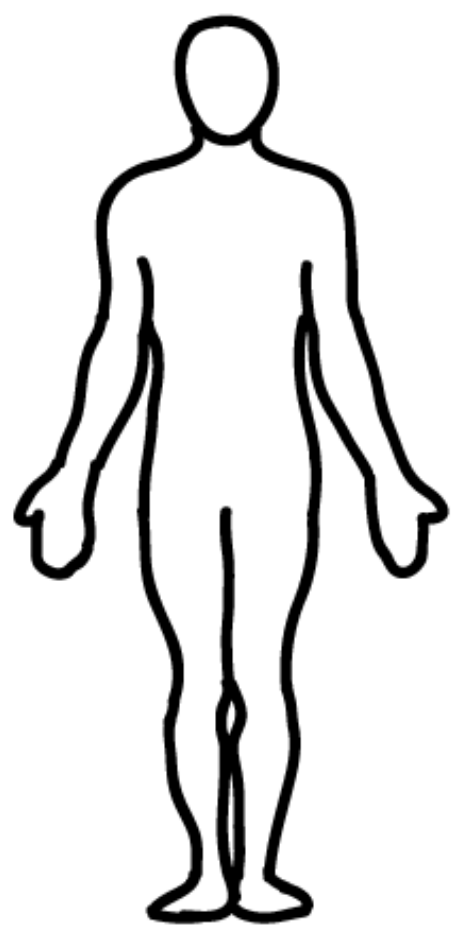

Por fim, optamos por solicitar um curto depoimento por escrito em língua portuguesa, com vistas a tornar mais prática a análise dos dados uma vez que os depoimentos orais teriam que ser transcritos e são mais suscetíveis às interferências do pesquisador. A extensão do dos depoimentos não foi restrita, mas recomendou-se que fosse de no mínimo cinco linhas, podendo ser estendido. Evidentemente, a competência de se expressar por escrito em língua portuguesa foi um pré-requisito para a participação na pesquisa. Essa tarefa foi explicada oralmente pela pesquisadora por meio do seguinte questionamento:

1. Porque você coloriu o retrato assim? Poderia dar maiores informações?

Outros aspectos dos procedimentos metodológicos precisam ser detalhados. A maior dificuldade em coletar dados que respondessem aos questionamentos elencados pelas discussões que foram desenvolvidas até então consistiu em encontrar candidatos que estivessem dispostos a participar do projeto.

Duas questões esclarecem essas dificuldades. Uma delas nos leva a considerar o receio que o sujeito na condição de refugiado sente quando abordado ou questionado sobre os seus propósitos no Brasil. Araújo (2003) afirma que, na condição do refúgio, o 
sujeito apresenta dificuldades em superar o medo de ser deportado. Além disso, as próprias circunstâncias que conformam o refúgio bem como a situação de humilhação social em que o sujeito se encontra fazem com que ele se sinta inseguro. Assim, é notável a dificuldade em empreender aproximações a esse grupo.

A outra, diz respeito à própria conduta da comunidade acadêmica. Hipotetizamos que, na ânsia de elaborar um estudo que contribua significativamente com uma causa social, o pesquisador assume uma atitude de buscar dados sem colaborar efetivamente com a causa que pretende abordar. Tal conduta objetifica os sujeitos da pesquisa e cria um distanciamento entre o meio acadêmico e o meio social. Como resultado, observa-se a resistência por parte de muitas organizações da sociedade civil e comunidades de refugiados em estabelecer parcerias com os pesquisadores.

Proponho que uma medida que pode superar esse distanciamento de maneira construtiva, tanto para o pesquisador, quanto para a comunidade dos refugiados, é o emprego da escuta, do diálogo e da convivência. Rizzo (2012), em seu estudo sobre o refúgio, afirma que a escuta atenta e presente pode favorecer não apenas a coleta de dados, mas também a construção de projetos que promovam a efetiva integração do sujeito que está refugiado assim como a conscientização da sociedade de acolhimento sobre o refúgio. De nada adianta buscar dados se a história desse sujeito, que muitas vezes é tudo o que ele traz consigo do seu país origem, permanece ignorada:

É comum que candidatos ao refúgio apresentem apenas a sua história: não portam documentos, e muitas vezes não podem fornecer elementos outros, além da própria narrativas como exame às autoridades estatais encarregadas de atestas a existência daquelas condições que ensejam a concessão da proteção internacional. (RIZZO, 2012: 100).

Rizzo (2012) ainda recomenda um pericioso cuidado por parte do pesquisador ao recepcionar quaisquer depoimentos, orais ou escritos, que sejam fornecidos pelo sujeito do refúgio. Ao nos debruçarmos sobre esses depoimentos, notamos que informações objetivas sobre o país de origem oferecem o contexto a partir do qual uma narrativa particular se desenha.

Com o intuito de obter dados que não objetificassem esse sujeito, buscamos conviver e conhecer o cotidiano dessas pessoas. Entre 2015 e 2016, integramos o Projeto de Pesquisa e Conteúdo do Programa de Advocacy do Instituto ADUS de Reintegração ao Refugiado em São Paulo. Em 2016, atuei como professora assistente de língua portuguesa na Missão Paz em São Paulo, ocasião em que pude lecionar para migrantes e refugiados que se encontravam em situação de vulnerabilidade social. E, 
atualmente, colaboramos com a Bibliaspa, instituição também localizada em São Paulo e dedicada promover a integração cultural por meio de aulas de língua portuguesa e aulas ministradas pelo próprio sujeito do refúgio. A instituição também organiza eventos culturais na cidade de São Paulo com o objetivo de conscientizar a sociedade sobre a questão do refúgio.

Essas oportunidades promoveram ricos encontros em que pudemos colocar em prática o exercício da escuta e da convivência, o que permitindo que fossem estabelecidas parcerias, assim como diálogos, trocas e amizades que viabilizaram o presente estudo. Ao todo, 7 pessoas, de nacionalidade colombiana e maiores de 18 anos, se interessaram em participar da pesquisa com a condição de que suas identidades não fossem reveladas devido ao receio persistente em relação às perseguições que sofreram em seus países de origem. Todos autorizaram o uso dos retratos linguísticos e dos depoimentos por meio de um Termo de Autorização.

Apesar do mosaico de nacionalidades que compõe o contexto do refúgio no Brasil, optamos por selecionar os colombianos devido ao quadro linguístico do país e da política linguística de reconhecer as línguas de origem indígena e africana como oficiais junto ao espanhol nos departamentos onde elas são faladas. Além disso, durante o andamento da pesquisa, mantivemos bastante proximidade com pessoas dessa nacionalidade, o que criou uma certa reciprocidade e favoreceu a coleta de dados.

Os 7 participantes da pesquisa, cinco mulheres e dois homens, residem em São Paulo há mais de três anos e todos frequentaram por pelo menos um ano aulas de língua portuguesa, o que lhes tornou aptos a elaborar breve depoimento por escrito e a compreender as orientações da pesquisadora, que foram dadas também em língua portuguesa, língua oficial do atual país de residência dos entrevistados. Os retratos linguísticos foram obtidos por meio de encontros individuais com cada sujeito e aconteceram em suas residências no período de outubro de 2017 a fevereiro de 2018.

Por fim, podemos sistematizar os procedimentos metodológicos realizados na seguinte sequência:

$1^{\circ}$ Etapa: Aplicação do questionário

$2^{\circ}$ Etapa: Confecção dos retratos linguísticos

$3^{\circ}$ Etapa: Depoimentos e reflexão linguística 


\section{V - Análise dos dados}

Os dados serão apresentados conforme um padrão: como não poderemos apresentar os nomes dos entrevistados, empregaremos nomes fictícios para referimo-nos a eles enquanto sujeitos e forneceremos algumas informações sobre a história deles. Essas informações aqui constantes só foram compartilhadas após serem analisadas e autorizadas pelos entrevistados.

As respostas que foram dadas no primeiro momento da entrevista acerca das línguas que os entrevistados declararam falar serão informadas para que depois, possamos descrever os retratos linguísticos. Para encerrar a análise dos dados, discutiremos os depoimentos que foram fornecidos sobre os retratos. A seguinte tabela resume os dados que serão apresentados a seguir no que concerne às línguas declaradas e às línguas retratadas e mencionadas nos depoimentos:

Tabela 3. Retratos linguísticos

\begin{tabular}{|c|c|c|}
\hline Nome & Línguas declaradas & $\begin{array}{c}\text { Línguas retratadas e } \\
\text { mencionadas nos } \\
\text { depoimentos }\end{array}$ \\
\hline Maria & Português, espanhol, inglês & $\begin{array}{l}\text { Português, espanhol, } \\
\text { inglês, pallenquero }\end{array}$ \\
\hline Ana & Português e espanhol & $\begin{array}{l}\text { Português, espanhol, } \\
\text { quéchua }\end{array}$ \\
\hline Antônia & Português, espanhol, inglês & Português, espanhol, inglês \\
\hline Joana & Português e espanhol & $\begin{array}{l}\text { Português, espanhol, } \\
\text { wayuu }\end{array}$ \\
\hline Regina & $\begin{array}{l}\text { Português, espanhol, inglês } \\
\text { e wayuu }\end{array}$ & $\begin{array}{l}\text { Português, espanhol, inglês } \\
\text { e wayuu }\end{array}$ \\
\hline João & Português, espanhol, inglês & $\begin{array}{l}\text { Português, espanhol, } \\
\text { inglês, pallenquero }\end{array}$ \\
\hline Pedro & $\begin{array}{l}\text { Português, } \\
\text { pallenquero }\end{array}$ & $\begin{array}{l}\text { Português, } \\
\text { pallenquero }\end{array}$ \\
\hline
\end{tabular}




\subsection{Maria}

Maria reside no Brasil há cinco anos e seis meses e há três anos teve a sua solicitação de refúgio outorgada. Aos 35 anos, diplomada em ciências contábeis, ela ainda não teve a oportunidade de exercer a sua profissão de formação. Para se manter financeiramente trabalha em um pequeno comércio e não possui vínculo empregatício formalizado mediante a lei. Ao ser interpelada sobre as línguas que conhece ou fala, a entrevistada declarou falar português, espanhol e inglês.

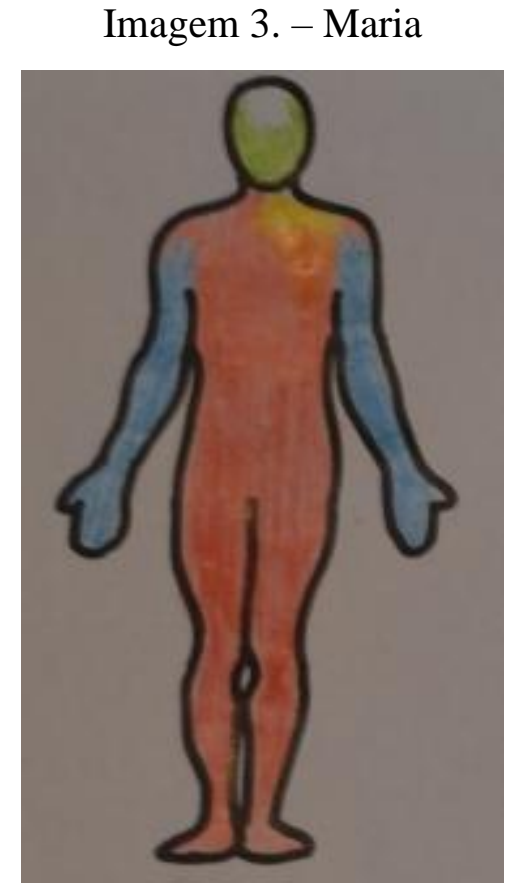

No retrato linguístico de Maria observamos quatro cores diferentes: vermelho, amarelo, azul e verde. Em seu depoimento, Maria alega que o vermelho retrata o espanhol, situado bem na região do coração, por ser a língua "do seu país"; o português foi colorido nos ouvidos e na boca, por ser a língua do "país em que ela mora". O inglês, retratado em azul e nos braços, foi assim representado para "mostrar que o inglês é muito bom às vezes quando ela não entende o português”. Curiosamente, uma língua a mais que não foi declarada no primeiro momento da pesquisa foi retratada na imagem. Em amarelo, Maria coloriu uma pequena porção na região do coração. Essa cor, segundo a entrevistada ${ }^{16}$, representa o pallenquero, uma língua que ela "quase não fala mais, mas ama".

\footnotetext{
${ }^{16}$ Os depoimentos foram reproduzidos integralmente conforme foram escritos.
} 
Jo pintei vermelho no espanhol porque é a cor de meu país. O português nos ouvidos porque é o país em que moro. O azul nos braços porque é muito bom quando eu não consigo entender nada. $O$ pallenquero em amarelo por quê é uma língua que quase não fala mais, mas eu amo.

\subsection{Ana}

Ana não nos autorizou a divulgação de sua idade. Reside no Brasil há quatro e teve a sua solicitação de refúgio concedida há três anos. Ela mora com as suas três filhas e sustenta financeiramente a família sozinha. Em sua resposta sobre quantas línguas conhece/fala, Ana declarou falar espanhol e português. No seu retrato linguístico diferenciamos quatro cores diferentes: a região do tronco para cima foi colorida em vermelho; a região do tronco para baixo foi colorida em amarelo e verde; os pés foram coloridos em preto.

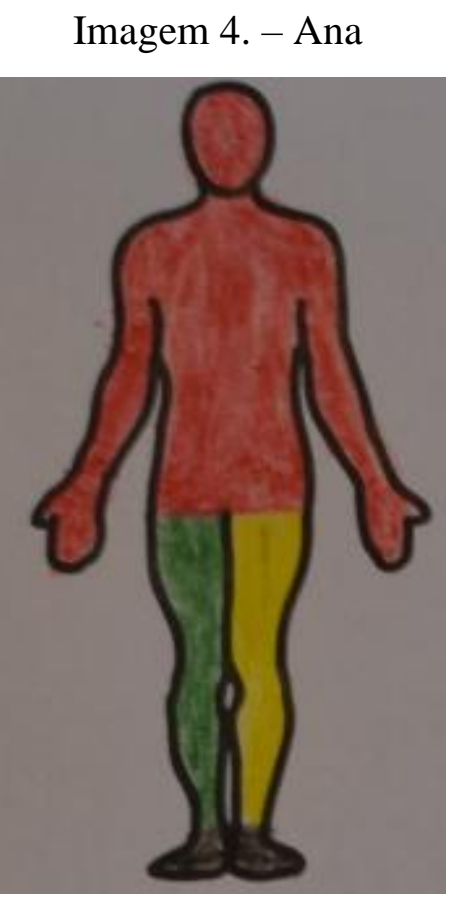

Em seu depoimento, Ana descreve o seu retrato da seguinte forma: o vermelho representa a sua língua "do coração"; o amarelo e o verde representam o português, em uma alusão às cores da bandeira do país que a acolheu; os pés foram coloridos em preto para representar uma língua “escura porque ela entende muito pouco e não fala mais". Trata-se do quéchua, uma língua que Ana representou para retratar a língua que a sua 
bisavó boliviana falava. Podemos entender esse gesto como um gesto de enraizamento ou vínculo com essa língua de herança.

$O$ vermelho é a língua do meu coração. $O$ verde y amarelo são o português porque a bandeira do Brasil. Os pés pretos são a língua quéchua que eu gosto muito. Minha bisavó da Bolívia falava quéchua. É uma língua escura porque eu entende muy poco e não fala mais.

\subsection{Antônia}

Antônia possui 21 anos e veio ao Brasil acompanhando a sua mãe, Joana, quando ainda era adolescente. Reside no país como refugiada há seis anos. Como ainda era menor de idade na ocasião em que veio ao Brasil, concluiu seus estudos em uma escola municipal. Em princípio, declarou falar português, espanhol e inglês. Curiosamente, essa entrevistada optou por detalhar o quão bem fala cada um dos idiomas. Segundo as suas respostas, ela fala "bastante" português e "mais ou menos" inglês e espanhol.

Em seu retrato, observamos três cores: vermelho, azul e amarelo. O vermelho foi empregado para representar a metade do seu corpo e foi associada ao espanhol; o português, colorido em amarelo, foi usado para colorir a outra metade. E por fim, para colorir as orelhas, ela usou o azul para representar o inglês, pois ela "gosta de ouvir músicas em inglês". Ao contrário dos demais retratos, não houve nenhuma referência às línguas de base indígena ou africana, provavelmente porque Antônia veio ao Brasil quando ainda era adolescente e pode ter tido pouco contato com essas línguas. 
Imagem 5. - Antônia

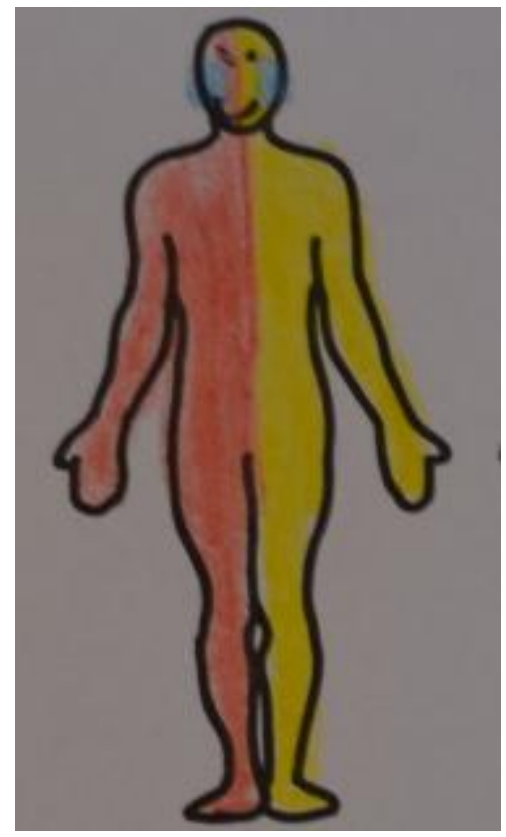

Por mais que a entrevistada tenha declarado inicialmente que fala mais português que espanhol, no desenho ambas as línguas foram retratadas de maneira quase que indistinta.

Pintei metade de vermelho porque é o espanhol. O português é a outra parte. Coloquei azul nas orelhas porque eu gosto de ouvir músicas em inglês.

\subsection{Joana}

Joana tem 40 anos e veio ao Brasil acompanhada de sua filha, Antônia. Divorciada, teve a sua solicitação de refúgio concedida há seis anos. Frequentou aulas de português, mas afirma que essa experiência foi muito difícil. Ao responder ao questionário inicial declarou falar espanhol e português. Em seu retrato linguístico constam quatro cores diferentes: vermelho, vermelho escuro, verde e amarelo. 


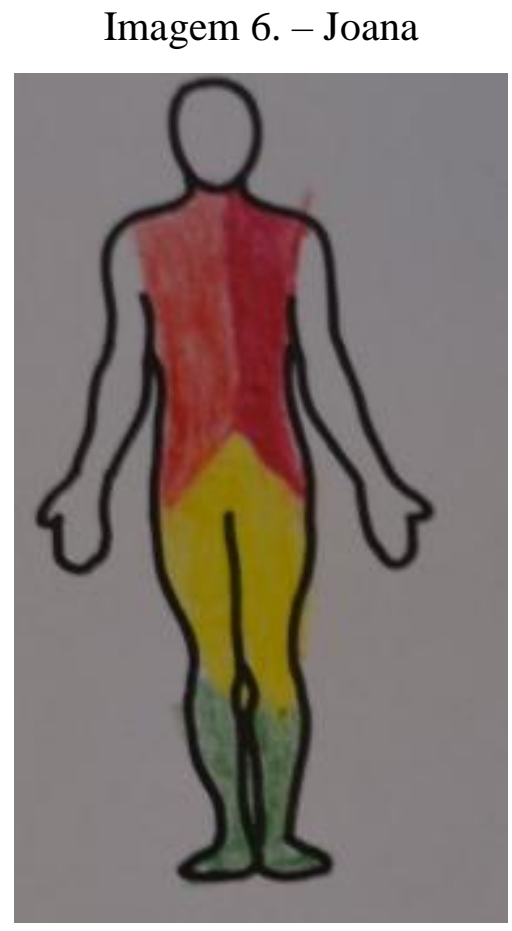

Em seu depoimento, Joana afirma que o vermelho, situado na região do peito, é o espanhol, "a principal língua que fala". O vermelho escuro, também representado em uma porção do peito, representa uma língua que a princípio não foi declarada pela entrevistada: o wayuu, uma língua da família Arawak. Segundo Joana essa é uma língua que lhe "encanta" e é falada por seus familiares; ela ainda declara que na Colômbia essa língua é "mal vista". O português foi colorido em verde e amarelo e nas pernas porque é "aqui que ela mora agora".

O vermelho fica no corazão porque é o espanhol a principal língua que falo. Más escuro é o vermelho do wayuu. Wayuu me encanta. Mas em Colômbia é mal vista. Para o português amarelo e verde nas perna porque eu moro aqui agora.

\subsection{Regina}

Regina é prima de Joana e reside no Brasil há cinco anos e teve a sua solicitação de refúgio concedida há quatro anos e três meses. Ela nos solicitou que a sua idade e quaisquer outras informações pessoais além dessas não fossem reveladas.

As suas respostas iniciais sobre quais línguas são faladas ou conhecidas por ela, Regina afirmou que fala português, espanhol, um pouco de inglês e um pouco de 
wayuu. Ao contrário da maioria dos entrevistados, Regina declarou uma língua de base indígena nesse momento inicial.

No seu retrato linguístico, constatamos quatro cores diferentes: vermelho, marrom, laranja e verde. O vermelho ocupou a maior porção do seu corpo porque para Joana essa língua retrata o espanhol a "língua que mais faz parte da sua vida"; o português foi distribuído na cabeça e nas mãos porque é a língua que ela "mais precisa falar, escrever e pensar". A cor escolhida para retratá-lo foi o verde em referência à cor da bandeira do país. O marrom foi usado para representar o wayuu nas pernas, a língua da "sua terra" e o azul, em uma pequena porção nos ombros, retratou o inglês porque ela consegue falar "um pouquinho".

Vermelho é o espanhol que é a língua que mais faz parte da vida. O português fiz colocar nas mãos e cabeça porque tengo que falar muito, escrever, pensar. Pintei verde por causa da bandeira. O marrom é a língua da minha terra, o wayuu. Um pouquinho de azul é o inglês porque só falo um pouquinho.

$$
\text { Imagem 7. - Regina }
$$

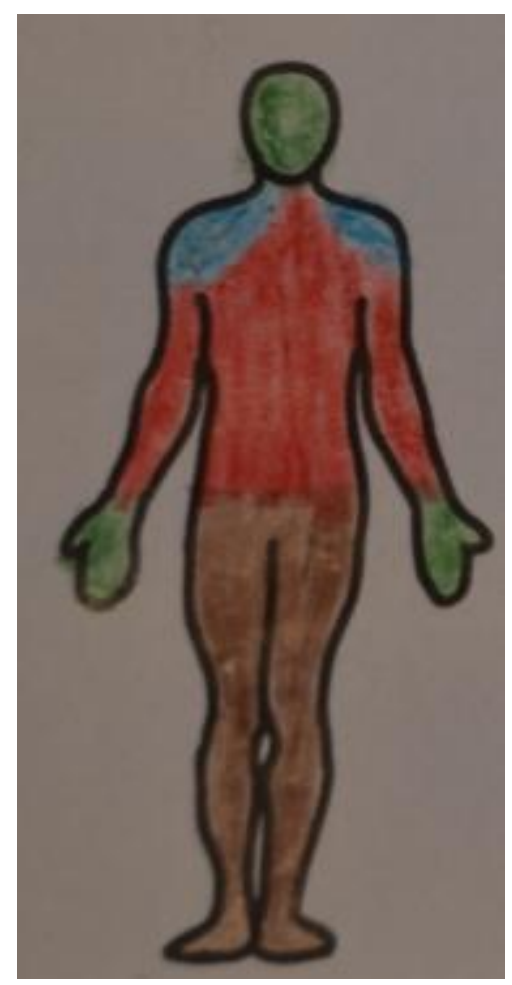




\subsection{João}

João tem 45 anos e reside no Brasil há seis anos; há cinco anos como refugiado. Diplomado em direito, ainda não conseguiu exercer a sua profissão de formação e atua como vigia noturno em uma fábrica localizada em São Paulo, junto com seu irmão Pedro. O entrevistado afirmou que sente muita vontade de voltar a exercer a sua profissão, mas que entende que faltam oportunidades para ele. Ele ainda afirma que gostou muito de estudar português nas aulas que frequentou em São Paulo.

Ao declarar as línguas que fala ou que conhece, João afirmou que fala português, espanhol e inglês. No entanto, percebemos que em seu retrato quatro línguas foram retratadas por meio de quatro cores diferentes: amarelo, verde, vermelho, azul

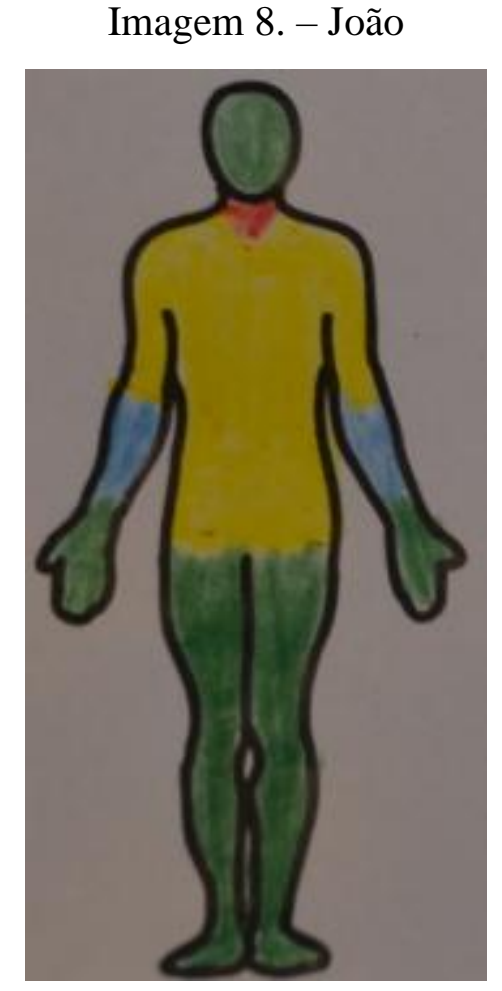

Em seu depoimento, João descreveu que optou por retratar em amarelo e na região do peito o espanhol porque lembra a cor da "camisa da sua seleção do seu país". Em vermelho, coloriu o pescoço para representar o pallenquero, língua que ele "fala muito" na Colômbia. Segundo o entrevistado ele gosta de cantar cantigas em pallenquero; por isso "colocou essa língua no pescoço". O azul foi colorido nos braços porque o inglês é uma língua que ele "consegue falar um pouco" e o verde ocupou as outras partes do corpo porque para ele é a língua que ele "tem que falar sempre". 
Gosto de futebol e coloquei amarelo para o espanhol. A camisa da seleção do meu país é amarela. O pallenquero eu falo muito em Colômbia. Me gosto de canta em pallenquero por isso coloquei no pescoço. O azul é inglês eu consigo falar un poco. $O$ verde é português que tem que falar sempre.

\subsection{Pedro}

Pedro veio com seu irmão para o Brasil. Aos 39 anos, trabalha como vigia noturno para sustentar financeiramente a seus filhos e sua esposa. Assim como João, encontra-se refugiado há cinco anos. Outras informações pessoais não serão descritas com vistas a respeitar o desejo do entrevistado em mantê-las em sigilo.

Ao informar quais línguas ele fala e conhece, Pedro declarou falar espanhol, português e pallenquero. Novamente, assim como Regina, o entrevistado inicialmente já afirmou falar uma língua de base africana além do espanhol e do português. Em seu retrato linguístico, três cores se combinam: o vermelho, o preto e o amarelo.

Imagem 9. - Pedro

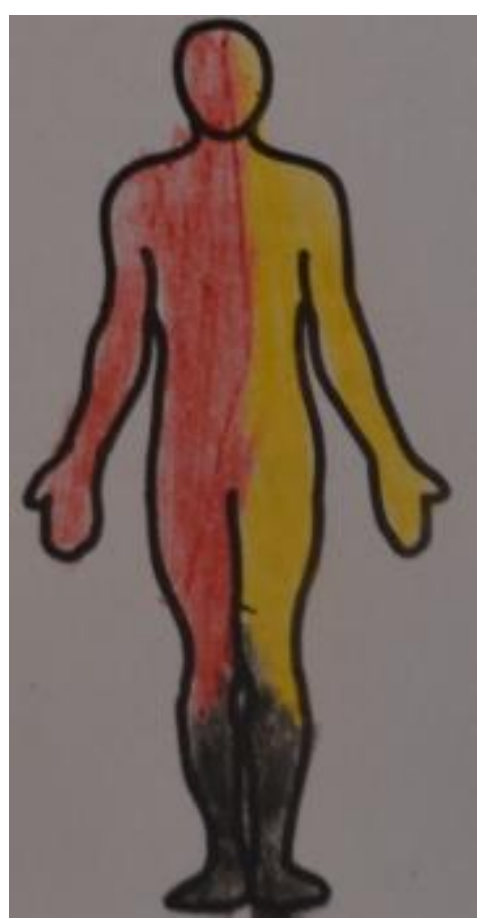

De acordo com o depoimento do entrevistado, o espanhol foi colorido em uma metade do corpo em vermelho porque é uma das "línguas que ele mais está acostumado a falar"; o amarelo foi empregado para colorir a outra metade de modo a retratar o 
pallenquero porque é uma das línguas que ele "mais gosta de falar". O português, ao contrário dos demais entrevistados, foi colorido em preto porque é uma língua que ele "acha muito difícil apesar de ser obrigado a falar".

Metade é vermelho porque espanhol é a língua que mais estou acostumado a falar. $O$ amrarelo é otra metade porque é pallequero que gosto de mais falar. Português é preto porque é muy dificil e é obrigado falar. 


\section{VI - (Des)atar nós: inquietações e reflexões}

Por meio dos retratos e dos depoimentos reunidos, inicialmente observamos uma disparidade entre as línguas que foram declaradas e as línguas que foram retratadas. Apenas para dois entrevistados houve uma equivalência entre ambas as línguas.

Em um dos casos, Antônia, hipotetizamos que o fato de ela ter vindo enquanto ainda era adolescente pode ter interferido nas relações linguísticas que foram estabelecidas de modo que, para ela, não há outras línguas a serem retratadas que não fossem o português, o espanhol e o inglês. As línguas de base indígena não foram enfocadas por ela.

Nos demais casos, as línguas maternas possuem um valor que é internalizado e que, em um primeiro momento, não é declarado sem que haja um processo de reflexão linguística. Daí deriva a disparidade entre os dados referentes ao questionário inicial e aos dados obtidos por meio dos retratos linguísticos. Em princípio, a resposta imediata parece ser dada como se o entrevistado valorasse e assumisse as línguas que parecem ser conhecidas pelo entrevistador; como se ele respondesse aquilo que ele considera ser esperado ou conhecido pelo entrevistador. Essa atitude não reconhece as suas línguas maternas.

Outras línguas, que não necessariamente são as línguas maternas do sujeito, também podem escapar de uma abordagem superficial, mas são reveladas por meio dos retratos linguísticos.

Vale ressaltar que, o espanhol, língua que foi indicada por todos os entrevistados no primeiro questionamento, é a língua oficial da Colômbia, mas também é a língua do colonizador, a língua do dominador. As demais línguas de base indígena e africana são oficiais apenas nos departamentos onde são faladas.

Por meio dos dados fornecidos é apreensível a atitude do sujeito, perante o outro, de optar assumir como língua falada/conhecida aquela que é mais prestigiada ou que, em princípio causará uma melhor impressão. No entanto, por debaixo dessa atitude pode haver outras línguas que são mais valorosas para o sujeito sem que ele, contudo, expresse essa atribuição positiva de modo explícito. O exercício de reflexão linguística serviu como um maneira de estimular a conscientização, tanto o entrevistado quando o entrevistador, em relação ao universo linguístico do sujeito que vive uma condição de multilinguismo. 
Joana, por exemplo, ao descrever o seu retrato afirma que o wayuu é uma língua que lhe traz encantamento, mas que na Colômbia é mal vista. Essas informações ganham ainda mais relevância quando cotejamos com a resposta que a entrevistada deu anteriormente, ocasião em que mencionou apenas o português e o espanhol como línguas que ela fala.

Segundo Mansen e Captain (2000) o wayuu, de base indígena, é falada por 105 mil falantes na Colômbia dos quais apenas $1 \%$ é alfabetizado nessa língua. As tensões culturais entre as novas gerações que falam wayuu levou o governo colombiano a promover iniciativas de integração o que corroborou para a publicação de uma dicionário espanhol-wayuu.

O retrato linguístico de Joana nos conduz a concluir que a conjuntura social e as dinâmicas de dominação social, de fato, projetam experiências de humilhação social. E tais experiências reverberam no sujeito de tal forma que atingem os valores atribuídos às línguas que ele fala, criando um contraste entre o é declarado como falado em uma entrevista vaga e o que realmente é internalizado na subjetividade.

Por sua vez, o retrato linguístico de Ana, nos informa sobre a presença de uma língua que ela mesma já não fala, apesar de sustentar um vínculo linguístico de importância com ela. Assim, as línguas de herança não parecem ser assim tão "inofensivas". Elas se fazem presentes nas manifestações identitárias e atam um vínculo de enraizamento do sujeito, por mais que ele não seja, ou por mais que ele não declare ser, linguisticamente competente.

Esse dado fornecido por Ana que, à primeira vista, pode parecer pontual, explicita uma diferença importante entre uso-linguístico e auto-identificação linguística: o falante pode não estar apto a empregar com destreza uma língua, mas isso não necessariamente significa que ele não se identifica com ela. Seals (2017: 27), em seu experimento com retratos linguísticos, já afirma: "Uso de língua não influencia diretamente e não é um reflexo direto de auto-identificação linguística"17.

Em geral, para esses falantes que não são nascidos no Brasil, o português figura como uma língua relevante. Ao contrário do que supúnhamos inicialmente, o português e as línguas maternas que o sujeito afirmou possuem uma dinâmica que não nos parece ser a mesma dinâmica de dominação entre o espanhol e o wayuu.

17 "Language use does not directly influence, and is not directly reflective of, linguistic selfidentification" (SEALS, 2017: 27). 
O português é uma língua que o falante "tem que falar sempre" ou é "obrigado a falar", uma vez que a sua presença é aqui tolerada; parece que ela é imposta de modo que ela é soberanizada: o sujeito fala português e, sobretudo, declara que fala português porque é "aqui que ele mora". Observamos, então, nuances de uma dominação cultural verificável em termos linguísticos que conduz o sujeito a buscar ser reconhecido no país de refúgio por meio da língua portuguesa.

Nos retratos linguísticos, a associação entre o português e as cores da bandeira do Brasil, juntamente coma declaração de obrigatoriedade em falar essa língua é recorrente. Essa constatação enquadra os dados nas categorias 3-4 de Coelho (2005): poder da língua é representado e associado a uma imagem política e de modo a vincular tal língua a referências culturais do país.

Já o modo de retratar as demais línguas de base indígena e crioula, em geral situadas na região do peito e descritas com valores afetivos - "é uma língua que amo falar" -, atam o vínculo do sujeito com as suas origens. Esses dados, por sua vez, ficam enquadrados nas categorias 1, o que não prevíamos a princípio, e 2: a língua como objeto afetivo, mas também como instrumento de construção e afirmação de identidades individuais e coletivas.

Não observamos a tendência de atribuir às línguas maternas de base indígena e africana um valor de poder político; somente ao português, que não é a língua materna desses falantes, e ao espanhol houve tal atribuição. Em contrapartida, as línguas maternas resistem perante essas línguas dominantes, apesar de quaisquer experiências de humilhação social, e conduzem o sujeito diretamente até a segurança de suas origens.

Outra língua retratada repetidamente foi o inglês; a essa língua foi atribuído um valor essencialmente prático e funcional em situações em que as interações são comprometidas por problemas de comunicação. Maria retrata o inglês de tal modo para "mostrar que o inglês é muito bom às vezes quando ela não entende o português". Já para Antônia o inglês a língua das músicas que ela gosta de escutar.

Cabe ainda destacar que o inglês foi retratado nos braços, coincidentemente com a constatação de Krumm (2003) que afirma que as línguas de valor prático costumam ser situadas nas pernas, braços ou mãos quando representadas nos retratos linguísticos. Ainda em consonância com o estudo de Krumm (2003), as línguas maternas constantes nos retratos linguísticos reunidos também foram situadas na região do coração ou do peito. Portanto, parece que realmente o sujeito estabelece relações psicoafetivas com as 
línguas e que tais relações possuem também uma dimensão concreta que é representada nos retratos linguísticos por meio dos índices de corporeidade.

O sujeito que protagoniza uma experiência multilíngue encontra-se em uma condição entre mundos: diferentes referências culturais, diferentes modos de se colocar perante o outro, diferentes modos de falar. A prerrogativa de tal condição é a diversidade, cultural e linguística, que, mesmo em situações adversas que comprometem a cidadania e impõem a língua dominante, persiste como um bastião multicolorido de resistência identitária.

Apesar da aplicabilidade dos retratos linguísticos propostos por Krumm (2003) ainda permanece uma inquietação metodológica: nos dados coletados observamos a recorrência entre os índices de corporeidade, cores e os valores atribuídos às línguas faladas pelo sujeito conforme sugerido pelo autor. No entanto, questionamos ainda em que medida essa recorrência pode ser considerada um padrão geral, uma vez que sujeitos de diferentes origens podem atribuir diferentes significados a elas: a cor vermelha, tão vinculada às línguas maternas nos dados que coletamos, pode ter uma denotação negativa para alguns povos. Supondo a coleta dos retratos confeccionados por sujeitos oriundos desses povos, pode-se verificar que a língua materna, quando valorada positiva e afetivamente, é retrata com outras cores.

Até o presente momento e com base na pesquisa realizada, a recorrência entre os dados é verificável sem que possamos afirmar que ela é universal a todos os contextos linguísticos. O que podemos afirmar é que as atribuições entre cor, índice de corporeidade e língua apresentam uma tendência a serem estabilizadas entre sujeitos que compartilham experiências linguísticas e culturais semelhantes.

Também pudemos verificar que quando o sujeito entrevistado realizou a tarefa de reflexão linguística por meio dos depoimentos, em geral houve uma valoração positiva e afetiva das línguas maternas. Assim, parece que o sujeito de nacionalidade colombiana e que se encontra refugiado no Brasil realmente identifica-se aparentemente com as atitudes linguísticas do país que o acolheu; por outro lado, essa identificação aparente não condiz necessariamente com a incorporação efetiva desses valores.

Essa constatação também nos leva a confrontar Damásio (2009) e o Princípio da Valoração. Conforme discutimos anteriormente, o autor afirma que o sujeito delibera ativamente na ocasião em que o Princípio da Valoração opera. Deliberar sobre algo pressupõe certa autonomia, como se o sujeito, independentemente do contexto, 
atribuísse valores ao que ele considera passível de ser mantido em seu cotidiano e o que deve ser descartado. Os informantes do nosso corpus apresentaram reações muito próximas quando confrontados com os mesmos questionamentos iniciais e quando apresentados às mesmas tarefas propostas. Sugerimos que essas reações podem ser entendidas como um indicativo de que o valor de uma língua não é atribuído com base nas inclinações particulares de cada sujeito, mas sim, com base na configuração cultural e social da condição em que ele se encontra.

Além disso, se o Princípio da Valoração operasse em total conformidade com a equação manter/descartar algo para promover a sobrevivência e o bem-estar do sujeito, seria adequado esperar que os resultados obtidos não retratassem as línguas de origem indígena e africana. Isso porque as imposições monolíngues e homogeneizantes do grupo dominante, seja na Colômbia, seja no Brasil, não dão espaço para a diversidade linguística e cultural. Há um forte impulso nesse contexto para que essas línguas sejam "derretidas" no melting pot. Mesmo assim, as línguas permanecem resguardadas na subjetividade do sujeito por mais que ele afirme o contrário.

Aliás, no contexto do refúgio, essas línguas podem ser até rotuladas como um indesejável empecilho para a efetiva integração. Os retratos linguísticos nos mostram, contudo, a necessidade de ponderar sobre como os processos de valoração são desencadeados. Em princípio há de maneira inegável um descompasso entre os valores que são declarados por meio de um roteiro de perguntas estruturadas e os valores que são declarados após um exercício de reflexão linguística. Por essa razão, propomos que há no Princípio da Valoração duas dimensões de análise: aquela que se faz por meio de dados obtidos sem que haja o exercício de reflexão linguística e aquela se faz após o exercício de reflexão linguística.

No descompasso entre valores declarados e valores retratados há o impacto promovido pelas experiências de humilhação social. No caso específico do refúgio e à luz dos retratos linguísticos, a necessidade de alcançar a aceitação e exercer uma cidadania que não é apenas aparente, leva o sujeito a atribuir declaradamente valores às línguas que são condizentes com aquilo que a sociedade de acolhimento estabelece. Para sobreviver e adquirir um senso de comunidade, o sujeito pode aparentemente adotar os valores que são preconizados pela sociedade dominante. 


\section{Conclusão}

O trabalho que propusemos, de caráter experimental, foi norteado pelo impulso teórico-metodológico de buscar meios alternativos de colher dados sem que o sujeito a ser entrevistado fosse objetificado e com vistas a atingir uma compreensão mais apurada da realidade linguística do sujeito que se encontra na condição de refugiado.

A necessidade de não objetificar dos entrevistados nos conduziu a compreensão de que a experiência do refúgio é também uma experiência de humilhação social que reverbera na subjetividade do sujeito de modo que ele pode ficar a mercê dos discursos de tolerância que são declarados pela sociedade de acolhimento e que promovem a marginalização e não a efetiva integração daqueles que estão refugiados no Brasil.

Observamos também que a configuração dessa experiência que encurrala o sujeito em um labirinto de tolerância e "gentil não respeito" (LOPES, 2009: 85) o priva do acesso ao que é mais fundamental para a convivência e integração social: a cidadania. Isso golpeia o sujeito de tal modo que ele se encontra em uma situação de vulnerabilidade social que o conduz a lutar pela sua sobrevivência ao assumir as atitudes, linguísticas ou não, da sociedade que lhe concedeu refúgio.

Essas considerações ganham ainda mais espaço quando constatamos que para a maioria da população que está refugiado no Brasil, a língua é apontada como a maior dificuldade enfrentada cotidianamente. Por essa razão e como recorte de análise optamos por estudar um dos componentes das atitudes linguísticas: a valoração. Para tornar o estudo possível se fez necessário amparar as nossas hipóteses no Princípio da Valoração (DAMÁSIO, 2009) e nos Retratos Linguísticos (KRUMM, 2003; 2010). Inicialmente, estudar os valores atribuídos às línguas por meio de desenhos e atividades de colorir nos causou certo estranhamento. Com a finalidade de superar tal estranhamento, debruçamo-nos mais detalhadamente sobre a proposta krummiana com vistas a compreender os métodos visuais.

Após realizar uma incursão teórica no tema dos métodos visuais, pudemos perceber que as atividades de colorir na realidade são atividades de reflexão linguística que permitem tanto a conscientização do sujeito que realiza o retrato quanto do pesquisador que observa o retrato. Os retratos linguísticos confeccionados por sujeitos de nacionalidade colombiana e que se encontram refugiados no Brasil nos forneceram 
ricas informações sobre os valores da realidade linguística deles, o que revelou não apenas embates e enlaces entre língua materna e língua estrangeira, mas também evidenciou as línguas de herança do sujeito. Também pudemos verificar, em consonância com o que Seals (2017) explana, que há uma diferença entre uso e identificação linguística. O sujeito pode falar uma língua sem se identificar com ela; ou ainda, ele pode se identificar com uma língua sem necessariamente falar.

Ainda resta uma inquietação referente à proposta de Krumm (2010) que, nessa ocasião, não conseguimos silenciar. Essa inquietação diz respeito ao modo com que o sujeito retrata as suas referências linguísticas e culturais. Conforme discutimos no decorrer desse estudo, não nos parece viável encontrar um padrão de atribuições linguísticas nos retratos linguísticos, apenas uma tendência à padronização entre sujeitos de uma mesma comunidade ou de uma mesma nacionalidade, uma vez que por mais que a identidade do sujeito seja socialmente construída, a sua subjetividade não parece ser passível de generalizações.

Outra inquietação diz respeito às diferenças culturais entre sujeitos de diferentes comunidades. Concluímos por meio da análise de dados que a relação entre cor, índice de corporeidade e línguas pode variar a depender das origens do sujeito. Sugerimos que o que representa uma relação simbólica positiva para determinadas nacionalidades pode ter uma conotação depreciativa para outras. E vice-versa.

Quando nos atemos diretamente aos valores atribuídos, Damásio (2009) nos orientou a compreender que situações de sobrevivência podem realmente alterar o processo de valoração de uma língua com vistas a atingir a aceitação perante o outro, o que no contexto do refúgio, promove uma suposta, porém questionável, integração.

No entanto, o processo de valoração não é desencadeado apenas pela deliberação autônoma do sujeito. Quando é declarado que uma língua é importante pare ele, seja numa entrevista baseada em questionários, seja numa pesquisa pautada em retratos linguísticos, é importante considerar que há um contexto social que interfere e atua na configuração da atitude linguística do sujeito de prestigiar ou depreciar uma língua.

Como prova disso, há a constatação da disparidade entre as línguas que foram declaradas no questionário inicial e as línguas que foram representadas nos retratos. Em um primeiro momento, o sujeito parece assumir as línguas que são conhecidas pelo entrevistador e não necessariamente as línguas com as quais ele realmente se identifica. A confecção dos retratos linguísticos juntamente com os depoimentos promove um 
exercício de reflexão linguística que evidencia línguas, com as línguas de herança, que em uma abordagem superficial podem não ser identificadas.

Em suma, os métodos visuais, sobretudo a proposta de Krumm (2003; 2010), consistem em procedimentos metodológicos eficientes na busca de informações referentes aos valores atribuídos às línguas que são faladas por um sujeito multilíngue e que podem ser empregados com o objetivo de abordar situações de humilhação social à luz de questões linguísticas.

Cabe ainda retornar ao mito de Ariadne que nos inspirou a propor o presente estudo. Não apenas as línguas maternas, mas também as línguas herança consistem em referências linguístico-culturais que promovem um senso de comunidade e pertença que orientam o sujeito em situações de vulnerabilidade social, como é o caso do refúgio.

Mesmo quando o sujeito não afirma falar a sua língua materna, ou quando ele não declara conhecer uma língua de herança, consideramos que essas referências linguísticas não podem ser simplesmente descartadas, por mais que haja um impulso de valoração que conduz o sujeito a adotar certas atitudes linguísticas. Essas línguas permanecem incorporadas ao sujeito e visíveis em seu retrato linguístico. É como se a “aquarela linguística" (LIMA-HERNANDES e CIOCCHI-SASSI: 2015) que compõe o seu país de origem cingisse a sua identidade com os fios das línguas maternas e das línguas de herança. Romper forçosamente com esse fio, ou ainda propor tal rompimento, consiste de um ato de desenraizamento que atenta contra a própria humanidade do sujeito. 


\title{
Anexos
}

\section{Artigo original $^{1819}$}

\author{
„Mein Bauch ist italienisch ... “ \\ Kinder sprechen über Sprachen
}

Hans-Jürgen Krumm (Wien)
Für jede Theorie des Fremdsprachenlernens ist die Frage entscheidend, ob bzw. wie explizites Wissen und Bewusstheit über die Fremdsprache ... den Fremdsprachenlernprozeß beeinflusst. (House 1998: 91)

Sprache spielt für die Herausbildung der menschlichen Identität eine zentrale Rolle: durch unsere Erstsprache wird es uns möglich, uns als Ich zu begreifen und zu artikulieren. Deshalb gibt es Menschen, die Hemmungen haben, eine andere Sprache zu lernen und zu sprechen, weil dies für sie eine Gefährdung ihrer mit Sprache verknüpften Identität darstellt. Als „Konfliktzweisprachigkeit" bezeichnen wir die Situationen, in denen Menschen gezwungen werden, eine andere Sprache zu übernehmen, zugleich aber ihre Erstsprache nicht aufgeben wollen. Ein Sprachwechsel gelingt um so besser, je weniger er als Bedrohung für die Erstsprache angesehen wird, je bewusster erkannt wird, dass verschiedene Sprachen uns verschiedene Seiten der Welt, aber auch verschiedene Möglichkeiten unseres persönlichen Welterlebens eröffnen.

\footnotetext{
${ }^{18}$ KRUMM, Hans-Jürgen. Mein Bauch ist italienisch. In: BAUMGARTEN, Nicole; BÖTTGER, Claudia; MOTZ, Markus; PROBST, Julia. (Orgs.). Übersetzen, interkullturelle Kommunikation,Spracherwerb und Sprachvermittlung - das Leben mit mehreren Sprachen. Bochum: AKS-Verlag, p.110-114, 2003.

${ }^{19}$ Esse estudo foi baseado em dados obtidos a partir de retratos linguísticos confeccionados por crianças. No entanto, em seu artigo "Multilinguismo em Retratos Linguísticos e Biografias Linguísticas de Migrantes" (Mehrsprachigkeit in Sprachenporträts und Sprachenbiographien von Migrantinnen und Migranten) Krumm (2010: 16) defende que esse mesmo método pode ser usado na coleta de dados que envolvam adultos uma vez que essa é "uma atividade que não só crianças, mas - talvez depois de uma curta hesitação - os adultos também se engajam com grande entusiasmo" e que possibilita o acesso às relações do sujeito com as línguas que compõem o seu universo linguístico.
} 
Kinder entwickeln ein solches Sprachbewusstsein früh, wachsen sie doch von Anfang an in eine vielsprachige Welt hinein. Sie merken, dass die Mutter anders mit ihnen spricht als der Vater, dass die Nachbarin wieder anders klingt. Spätestens im Kindergarten treffen sie auf anderssprachige Kinder. Oder sie gehören selbst in eine vielsprachige Familie, haben bis zum Schulbeginn bereits eine vielsprachige Lebensgeschichte. Dadurch, dass Schule diese Vielsprachigkeit und die Spracherfahrungen der Kinder vielfach ignoriert, macht sie ihnen weder das Erlernen der deutschen Sprache noch den Frühbeginn mit anderen Sprachen leichter. Viel zu oft tut Schule noch so, als säßen da einsprachige, gleichsprachige SchülerInnen, die nun auch im Gleichschritt in eine neue Sprache einsteigen (vgl. Gogolins Hinweis auf den „monolingualen Habitus" der multikulturellen Schule in Gogolin 1994). Sprachenlernen wird aber erleichtert, wenn dabei der vorhandene Sprachbesitz genutzt und das ohnehin vorhandene Nachdenken der Kinder über ihre Sprachen in den Unterricht einbezogen wird. Die Anfertigung von Sprachenporträts - so meine Erfahrungen beim Anfertigen von Sprachenporträts durch Kinder im Alter zwischen 7 und 14 Jahren (vgl. Krumm 2001) - erlaubt es schon im Grundschulalter, dass Kinder ein solches Sprachbewusstsein entwickeln und sich ihres vorhandenen Sprachenreichtums bewusst werden. Dazu bedarf es allerdings einiger Spielregeln, die es den Kindern erlauben, sich ohne Angst auf diesen Bewusstwerdungsprozess einzulassen:

1. Die Anfertigung von Sprachenporträts ist freiwillig. Manche Kinder haben eventuell schon schlechte Erfahrungen mit ihren Sprachen gemacht - das gilt für Migrantenkinder, die nicht überall erzählen durften, dass ihre Muttersprache Kurdisch ist, das gilt aber auch für Kinder, die wegen ihres Dialekts gemahnt wurden.

2. Für ihr Sprachenporträt erhalten die Kinder Silhouetten, in die hinein sie mit Farbstiften ihre Sprachen malen können. Das soll zunächst einmal ein Malereignis sein, d.h. die vorgegebenen Silhouetten sollten schnörkellos und relativ abstrakt sein (vgl. Krumm 2001: 100f.), so dass die Kinder phantasievoll daran gehen können, diese Figuren ganz oder

110

teilweise auszumalen, evtl. auch zu bekleiden, ihnen Haare auf den Kopf oder "Sprachschuhe“ an die Füße zu malen. Denn die Kinder haben ganz unterschiedliche Vorstellungen davon, wo und weshalb ihre Sprachen im Körper verteilt sind:

Felix, 11 Jahre

Englisch ist bei mir im Kopf, weil es mir Spaß macht. Spanisch ist bei mir im Körper weil ich Spanien sehr mag. Bei mir ist Deutsch in den Händen, weil ich sehr viel schreibe. Italienisch ist in den Beinen weil ich dort schon oft war.

Jogie, 11 Jahre

Yoruba ist bei mir im Körper, weil der Körper nicht hören kann und ich kann Yoruba nicht so gut verstehen. Englisch ist bei mir im Kopf, weil ich mich manchmal ziemlich konzentrieren muss um mir Vokabeln zu merken. Französisch ist bei mir in den Beinen, weil es für mich sehr fern liegt es richtig zu lernen obwohl das mein Wunsch ist. Und um in die Ferne zu gehen muss man Beine haben.

3. Es sollten keinerlei Vorgaben gegeben werden, wie die Sprachen in den Körper gemalt werden, auch nicht, ob etwas dazu zu sagen oder schreiben ist. Wenn Kinder ihre Porträts beschriften wollen (und können), so dürfen sie das natürlich. Meine Erfahrung ist, dass sie das durchweg gerne tun. Auch sollte gar nicht angesprochen werden, wie gut man eine Sprache können muss, um sie einzumalen. Die Lehrenden sollten sich hier ruhig etwas vage ausdrücken: alle Sprachen, die ihr kennt, von denen ihr etwas könnt. Es ist wichtig, dass die Kinder ihre Gedanken zu ,ihren Sprachen“ äußern und nicht durch normative Vorgaben daran gehindert werden. 
Denise, 11 Jahre

Ich habe nach meinem Gefühl gemalt. Ich habe nicht nach meinem Können gemalt.

Benjamin, 11 Jahre

malt Italienisch in sein Farbporträt, obwohl er es nicht kann:

Italienisch ist eine schöne Sprache.

Auch Schwedisch findet sich hier großflächig eingemalt: In Schwedisch verstehe ich nur ein Wort

„Guten Tag“.

4. Die Sprachenporträts müssen „veröffentlicht“, sie dürfen nicht einfach weggelegt oder eingesammelt werden. Für viele Kinder wird das Malen eines Sprachenporträts eine erste Gelegenheit sein, etwas von ihren Sprachen zu berichten. Es ist oft eine neue Erfahrung für sie, überhaupt danach gefragt zu werden (unter anderem, weil viele bestenfalls eine Zweisprachigkeit vermuten und sich mit der Frage nach der Muttersprache zufrieden geben).

Je nach Situation in der Klasse sollten alle, die wollen, ihr Porträt zeigen und dazu etwas erzählen. Dabei kommen vielfach Sprachkonflikte, Migrationsgeschichten, aber auch die persönlichen Vorlieben und (Sprachlern-)Ängste zum Ausdruck. 
Martin, 12 Jahre

Englisch ist bei mir im Kopf, weil ich bei dieser Sprache etwas nachdenken muss. Deutsch ist bei mir in den Armen, weil das meine Muttersprache ist und daher sehr leicht ist. Italienisch ist bei mir im Bauch, weil ich es fast nicht kann ...

Ferenc, 12 Jahre

Mein Herz ist ungarisch. Die wichtigsten Teile meines Körpers sind ungarisch. Mein Bauch ist Italienisch, weil ich gerne Italienisch esse. Meine Beine sind Deutsch, weil ich im deutschen Sprachgebiet lebe...

(Krumm 2001: 89)

Solche Erläuterungen zu den Sprachenporträts können im Nachhinein angefertigt oder abgegeben werden. Dazu ist es sinnvoll, die Bilder in der Klasse aufzuhängen und - eventuell in einer späteren Stunde - zu den Porträts mündlich etwas zu erzählen, sie mit Stichwörtern beschriften zu lassen oder gar ab der 3. oder 4. Klasse einen kleinen Text schreiben zu lassen. Wichtig dabei ist, dass die einzelnen ,SprachbesitzerInnen' Gelegenheit haben, ihr Sprachkönnen in der Klasse zu zeigen. Dazu bieten sich außer den Beschriftungen und Geschichten folgende Möglichkeiten an:

- jedes Kind, das will, darf zu ein oder zwei Sprachen aus seinem Porträt ein Wort oder einen Text (Gedicht oder Lied) sprechen,

- jedes Kind darf zu seinen Sprachen etwas mitbringen: eine Münze, auf der etwas in dieser Sprache steht, eine Konservendose, Speisekarte, irgendeinen Text in dieser Sprache oder einfach einen Gegenstand aus dem Land, in dem diese Sprache gesprochen wird.

5. Die ganze Klasse soll mit Hilfe der Sprachenporträts in die Sprachenvielfalt der Welt eintauchen.

Ebi aus dem Iran, 10 Jahre

Englisch hat grüne Farbe, weil dort immer es regnet.

Arabisch hat braune Farbe, weil arabische Länder viele Wüsten haben.

Deutsch hat schwarze Farbe, weil Deutsch schwer ist.

Persisch hat blaue Farbe, weil dort schöne Himmel hat.

(Krumm 2001: 75)

Auf einer Landkarte können mit farbigen Fähnchen die Länder markiert werden, in denen die jeweilige Sprache „zuhause“ ist und gesprochen wird. Dabei können die SprachbesitzerInnen kontrollieren, ob die anderen auch die richtigen Länder gefunden haben. Gibt es Kinder in der Klasse, die aus diesen Ländern kommen, dort eventuell Verwandte haben und Besuche machen, so lassen sich die Wege (,Wie kommt man dahin?“", „Wie bist du hierher gekommen?") rekonstruieren und einzeichnen.

Auch der umgekehrte Weg ist denkbar: Jedes Kind sucht zu Hause nach einem Text in einer anderen Sprache - (schon die Windelpackungen sind mehrsprachig beschriftet, d.h. jede/r müsste etwas finden) - dann wird geprüft, ob es in der Klasse jemanden gibt, der/die diese Sprache kann, eventuell sogar den Text schon lesen kann.

Schließlich lassen sich Sprachenquartetts spielen: Die Klasse wird in Vierergruppen geteilt, in denen vier verschiedene Sprachen vertreten sind. Jede Vierergruppe erhält ein Wort, von dem zu vermuten ist, dass es jede/r in einer seiner Sprachen kennt (Mutter, Kind, bitte, danke, Haus etc.) und schreibt dieses in seiner/ihrer Sprache auf eine Karte. Die Karten werden eingesammelt, gemischt und ausgeteilt. Nun müssen sich die Quartette finden, wobei 
die SprachbesitzerInnen als die wichtigen Auskunftspersonen gefragt werden können. Aber natürlich muss man zuerst herausfinden, welche Sprache man auf seiner Karte stehen hat: Aus welcher Sprache stammt ekmek und was heißt es. Gibt es Kinder mit griechischer oder russischer Muttersprache in der Klasse und können diese auch schreiben, so sollten in jedem Fall entsprechende Karten dabei sein - das kann man als LehrerIn auch vorbereiten, also solche Karten mit Hilfe eines einfachen Reisewörterbuches erstellen und den jeweiligen Kindern geben. Dann ist für die anderen die Frage, welche Sprache das ist, und das AhaErlebnis (vielleicht hat man das Wort gesprochen schon einmal gehört) um so größer.

6. Die „Leiblichkeit“" (Schwerdtfeger 2000) der Spracherfahrung von Kindern muss bei der Arbeit mit den Sprachenporträts wie auch beim frühen Fremdsprachenlernen berücksichtigt werden: Die Kinder verleiben sich, indem sie ihre Porträts zeichnen, die Sprache im Wortsinne ein und haben vielfach dieses Gefühl einer unmittelbaren Beziehung zwischen ihrem Körper und ihren Sprachen.

Cristina, 14 Jahre

Deutsch: im Kopf, weil es die Sprache ist, in der ich denke

Spanisch: im Kopf, weil meine zweite Muttersprache

Englisch: im Hals und Füßen, ... nicht fließend. Ich kann mich oft nicht ausdrücken, wie ich will „,kalte Füße", „Frosch im Hals ".

Italienisch: im Herzen, weil ich sie unbedingt sprechen möchte und ich das Land liebe.

Dass Valon seinen Körper von oben bis unten in zwei Hälften (blau - Deutsch, rot Albanisch) teilt (vgl. Krumm 2001: 11), dass nahezu bei der Hälfte aller Sprachenporträts die Mutterfarbe in roter Farbe als Herz oder zumindest dort, wo das Herz sitzt, eingezeichnet ist, dass die Sprachen in Kopf, Händen und Beinen für die Kinder eine so wichtige Rolle spielen, sollte im Unterricht zur Sprache kommen, z.B. durch Sprachwink-Übungen: Zu einem englischen Lied oder Text dürfen alle, die Englisch in den Kopf gemalt haben, mit dem Kopf wackeln, die, die es in den Händen haben, dürfen dabei winken, die, die es in den Beinen oder Füßen haben, dabei tanzen - dasselbe nun für alle Sprachen, die in der Klasse mehrfach vertreten sind.

Auch individuelle Übungen sind denkbar. Cristina, die Englisch im Hals hat, darf einmal Englisch krächzen; diejenigen, die Italienisch im Bauch haben, weil sie so gern Italienisch essen, sollen versuchen, ein Wort wie Spaghetti möglichst korrekt italienisch auszusprechen. Diejenigen, die Deutsch als schwarz und schwer eingemalt haben, dürfen sich einmal leichte deutsche Wörter für die Arme oder Beine überlegen, z.B. Fremdwörter, die sie aus der Muttersprache kennen und die deshalb gar nicht so schwer sind. Solche Formen der „Einverleibung“ helfen, Sprechängste und Sprachhemmungen zu überwinden.

7. Ein Klassen- oder Schulporträt soll deutlich machen, dass nicht nur Individuen, sondern die ganze Klasse/Schule/Stadt über einen großen Sprachenreichtum verfügt. Zunächst einmal könnte ein Klassen-Sprachbarometer angefertigt werden, auf dem eingezeichnet wird, wie viele verschiedene Sprachen in der Klasse gesprochen werden. Mit jedem Wort in einer neuen Sprache, mit jedem Kind, das neue Sprachen in die Klasse bringt, steigt dieses Barometer (das erleichtert hinzukommenden Kindern den Einstieg, denn sie tragen evtl. unmittelbar zum Ansteigen des Barometers bei). Vielleicht entsteht daraus ein Schulbarometer. Auf die Dauer lässt sich mit Farben unterscheiden: wie viele Sprachen können wir sprechen, in wie vielen Sprachen können wir schreiben, wie viele Sprachen kommen zusammen, wenn wir Freunde, Eltern usw. fragen. Schader (2000: 109f.) schlägt 
dafür das Anfertigen einer Sprachentabelle in der Klasse (oder Schule) vor, die allmählich erweitert wird.

Bei all diesen Aktivitäten ist es wichtig, die übergreifenden Zielsetzungen im Blick zu behalten, von denen her auch eine Auswahl zu treffen ist:

- Die Kinder sollen sich ihres Sprachenreichtums bewusst werden - das gilt gerade auch für die Migrantenkinder, die vielleicht mehr Fehler im Deutschen machen, dafür aber zum Sprachenreichtum ihrer Klasse beitragen.

- Es soll ein Sprachenbewusstsein entstehen, das dazu führt, dass Kinder Sprachenlernen und Mehrsprachigkeit als selbstverständliches Element ihrer Lebenswelt begreifen. Das erleichtert es auch, sie für das Erlernen weiterer Sprachen zu begeistern.

- Die Kinder sollen die Erfahrung machen, dass man sich auch mit Menschen, die anders sind, die anders sprechen, die anders aussehen, verständigen kann, dass man von diesen etwas lernen kann.

Für Lehrende könnte die Erkenntnis von der Vielsprachigkeit des Klassenraumes ein Anlass sein, den Kindern mehr zuzutrauen, ihnen in stärkerem Maße das Wort zu geben und vielleicht auch selbst wieder Lust auf das Entdecken neuer Sprachen zu bekommen. Zugleich ermöglichen Sprachenporträts und ihre Kommentierungen durch die Lemenden einen Zugang zu den subjektiven Theorien junger Sprachenlernender, eine, um mit House zu sprechen, bessere Berücksichtigung von Emotion und Kognition:

die größere Komplexität der existierenden kognitiven Vernetzung [dürfte] ein verstärktes Bewusstmachen sprachlicher und kultureller Strukturkontraste und Ähnlichkeiten erforderlich machen [...], d.h. metasprachliche und metapragmatische Bewusstheit müsste in ganz besonderem Maße gefördert werden, damit das, was ein Lernender schon weiß, voll genutzt werden kann. (House 1998: 95)

\section{Bibliografie}

Gogolin, I. 1994. Der monolinguale Habitus der multilingualen Schule. Münster: Waxmann.

House, J. 1998. Kognition und Emotion beim Lehren und Lernen fremder Sprachen. In K. -R. Bausch et al. (eds), Kognition als Schlüsselbegriff bei der Erforschung des Lehrens und Lernens fremder Sprachen. Tübingen: Narr, 89-97.

Krumm, H.-J. 2001. Kinder und ihre Sprachen - lebendige Mehrsprachigkeit. Wien: Eviva.

Schader, B. 2000. Sprachenvielfalt als Chance. Zürich: Orell-Füssli.

Schwerdtfeger, I. C. 2000. Leiblichkeit und Grammatik. In H. Düwell, C. Gnutzmann \& F. Königs. (eds), Dimensionen der Didaktischen Grammatik. Festschrift für Günther Zimmermann zum 65. Geburtstag. Bochum: AKS-Verlag, 281-303.

${ }^{1}$ Dieser Beitrag wird in gekürzter Form in der Zeitschrift „Grundschule Sprachen“ erscheinen.

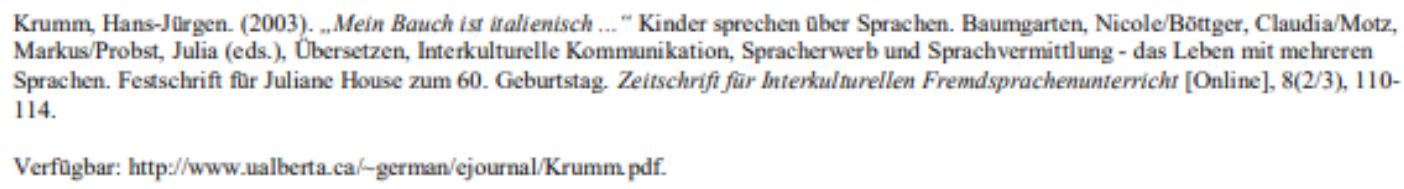

Krumm, Hans-Jürgen. (2003). .. Mein Bauch ist italienisch ... " Kinder sprechen uber Sprachen. Baumgarten, Nicole/Bõttger, Claudia/Motz, Markus/Probst, Julia (eds.), Óbersetzen, Interkulturelle Kommunikation, Spracherwerb und Sprachvermittlung - das Leben mit mehreren Sprachen. Festschrift für Juliane House zum 60. Geburtstag. Zeitschrift für Interkulnurellen Fremdsprachenunterricht [Online], 8(2/3), 110114.

Verfugbar: http://www_ualberta_ca/-german/ejournal/Krumm.pdf. 


\section{Artigo traduzido}

"A minha barriga é italiana" - O falar das crianças sobre as suas línguas Hans-Jürgen Krumm (Wien)

A língua exerce no desenvolvimento da identidade do sujeito um papel central: por meio de nossa primeira língua torna-se possível compreender-nos como sujeitos e, assim, articular-nos. Por essa razão há quem possua dificuldades para aprender a falar uma outra língua. Isso porque o ato de aprender uma nova língua pode representar uma ameaça relacionada à língua e à sua identidade. Entendemos por conflito de bilinguismo as situações em que os falantes são obrigados a assumir uma segunda língua, mas ao mesmo tempo não desejam renunciar à sua primeira língua. Quanto menos ameaçadora parecer uma segunda língua e mais evidente for para o falante que diferentes línguas revelam diferentes facetas do mundo e também descortinam diferentes possibilidades para a nossa experiência pessoal de mundo, então, o processo de aprendizagem será consideravelmente mais bem sucedido.

As crianças desenvolvem logo cedo uma certa consciência linguística e crescem em um mundo multilinguístico. Elas percebem que a mãe fala com elas de um jeito que é diferente do pai e ainda que a vizinha soa de um outro jeito quando fala. Mais tarde, no jardim da infância, elas encontram crianças falantes de outras línguas. Ou elas mesmas pertencem a uma família multilinguística e possuem até atingirem a idade escolar uma história de vida multilinguística. Ao ignorar esse multilinguismo e a experiência de língua das crianças, a escola não torna o aprendizado da língua alemã e de outras línguas mais fácil.

Muito frequentemente, as escolas atuam como se recebessem apenas alunos monolíngues que serão introduzidos em condição de igualdade numa nova língua (cf. considerações de Gogolins sobre os hábitos monolíngues das escolas multiculturais, 1994). No entanto, o aprendizado de línguas seria facilitado se as habilidades linguísticas juntamente com as reflexões das crianças sobre as suas línguas fossem incluídas nas aulas. A produção de retratos linguísticos - conforme a minha experiência com a produção de retratos linguísticos por crianças na faixa etária de 7 a 14 anos (cf. Krumm 2001) - permitiu constatar que já na idade escolar as crianças desenvolvem consciência linguística e se conscientizam sobre a sua riqueza linguística. No entanto, 
para que essa atividade seja bem sucedida é preciso que algumas regras que permitam que as crianças se expressem sobre tais processos de conscientização e se envolvam com eles sem medo sejam estabelecidas:

1. A produção dos retratos linguísticos é voluntária. Algumas crianças vivenciaram experiências negativas em relação às suas línguas - isso vale, por exemplo, para filhos de migrantes, que foram proibidos de dizer que a sua língua materna é curdo e vale também para crianças que foram caçoadas em razão da variedade linguística que falavam.

2. Para o retrato linguístico as crianças devem receber silhuetas que serão coloridas com lápis de cor de modo a representar as suas línguas. Em princípio, o retrato linguístico deve ser uma atividade de pintura, isto é, as silhuetas distribuídas devem ser diretas e relativamente abstratas, de modo que as crianças possam imaginar e começar a colorir essas figuras, no todo ou em partes, e eventualmente vesti-las, cobrindo a cabeça com cabelos ou desenhando "sapatos linguísticos". Isso porque elas possuem diferentes percepções sobre onde e porque cada uma de suas línguas estão distribuídas em seu corpo.

Felix, 11 anos

O inglês está na minha cabeça, porque ele é divertido. O espanhol está no meu corpo porque eu gosto muito de espanhol. Para mim o alemão está nas minhas mãos, porque eu escrevo muito. O italiano está nas minhas pernas porque eu já fui muitas vezes para lá.

Jogie, 11 anos

Para mim o Yoruba está no corpo, porque o corpo não consegue ouvir e eu não consigo entender muito bem Yoruba. O inglês está para mim na cabeça, porque eu às vezes tenho que me concentrar muito para memorizar palavras. O francês está para mim nas pernas, porque ele (o francês) fica muito longe de mim e é difícil de aprender certo apesar de eu desejar isso. E para ir longe, é preciso ter pernas. 
3. Não deve haver diretrizes sobre como as línguas serão pintadas no corpo, inclusive se a criança deve dizer ou escrever algo. Quando as crianças quiserem e puderem descrever o seus retratos, elas devem o fazer naturalmente. A minha experiência indica que elas o fazem de bom grado durante a atividade. Além disso nada deve ser comentado sobre o quão bem se deve falar uma língua para que ela seja retratada no desenho. Aqui os professores devem se expressar discretamente e vagamente: todas as línguas que vocês conhecem e que vocês conseguem falar algo podem ser representadas. É importante que as crianças expressem as percepções sobre "suas línguas" e não se sintam impedidas por meio de diretrizes normativas.

\section{Denise, 11 anos}

Eu colori de acordo com o meu sentimento. Eu não colori de acordo com a minha capacidade de falar.

\section{Benjamin, 11 anos}

(Coloriu em seu retrato o italiano, apesar de não conseguir falar)

Italiano é uma língua bonita.

Também coloriu com destaque o sueco

Em sueco eu entendo apenas uma palavra: "Boa tarde"

4. Os retratos linguísticos devem ser expostos, eles não devem deixados de lado ou recolhidos. Essa atividade pode ser para muitas crianças uma primeira oportunidade de dizer algo sobre suas línguas. Esse momento é frequentemente uma nova experiência, sobretudo de questionamento para elas (em parte porque muitas assumem que são bilingues e encontram-se satisfeitas com a questão da língua materna). A depender da situação em sala de aula, todos os que quiserem devem mostrar os seus retratos e contar algo sobre ele. Nessa ocasião muitos conflitos linguísticos, histórias de migração, mas também preferências pessoais e medos (de aprendizagem de línguas) veem à tona.

Martin, 12 anos

Em mim o inglês está na cabeça, porque com essa língua eu tenho que pensar alguma coisa. O alemão está nos braços, porque ele é a minha 
língua materna e por isso é muito fácil. O italiano está na minha barriga, porque eu não consigo falar quase nada.

Ferenc, 12 anos

O meu coração é húngaro. As partes mais importantes do meu corpo são húngaras. A minha barriga é italiana, porque eu gosto de comer comida italiana. Minhas pernas são alemãs, porque eu vivo em uma região onde se fala alemão.

Essas explicações dos retratos linguísticos podem ser feitas ou enviadas posteriormente. Assim, faz sentido expor as imagens na sala e - eventualmente em uma próxima aula contar algo sobre os retratos, rotulá-los com palavras-chave ou até mesmo a partir da terceira ou quarta aula escrever um pequeno texto. Assim, é importante que cada sujeito $^{20}$ tenha a oportunidade, de mostrar para o grupo as sua competência linguística. Por isso, sugere-se que além das descrições e histórias sejam propostas as seguintes tarefas:

-cada criança, que assim o queira, pode falar uma palavra ou um texto (um poema ou uma canção) sobre um ou duas línguas representadas no seu retrato.

-cada criança pode trazer algo sobre as suas línguas: uma moeda, em que há algo escrito nessa língua, uma lata de conservas, um cardápio, qualquer texto nessa língua ou até mesmo um objeto do país, onde se fala essa língua.

5. Todo o grupo deve se envolver, com o auxílio dos retratos linguísticos, na diversidade linguística do mundo.

Ebi, Irã, 10 anos

Inglês tem a cor verde, porque lá sempre chove.

Árabe tem a cor marrom, porque os países árabes têm muitos desertos.

Alemão tem a cor preta, porque alemão é difícil.

Persa tem a cor azul, porque lá tem um céu bonito.

\footnotetext{
${ }^{20}$ A tradução direta do termo empregado por Krumm é Sprachbesitzer, proprietário de línguas. Nos pareceu que expressão em português traz uma série de problemas de ordem conceitual, uma vez que coloca a língua como um objeto estanque, estável e passível de ser mecanicamente possuído.
} 
Em um mapa podem ser marcados os países com bandeirinhas coloridas, onde cada língua está "em casa" e é falada. Assim, outros falantes podem e conseguem observar se outros colegas encontraram os países certos. Há crianças na sala que vêm de outros países e eventualmente possuem parentes que vivem lá e os visitam e com isso é possível para eles reconstruir e desenhar os trajetos percorridos ("Como se vai até lá?/ Como você foi de lá até aqui?)

O caminho contrário também é possível: cada criança procura em casa um texto em uma outra língua (as embalagens de produtos costumam ser uma boa fonte de informações pois são escritas em mais de uma língua ${ }^{21}$; isso significa que cada um poderá achar alguma coisa interessante) - então, será verificado se há alguém na sala que consegue falar essa língua e, eventualmente, até mesmo ler o texto.

Finalmente é possível propor um jogo de "quartetos linguísticos": a sala será dividida em 4 grupos, no quais 4 línguas serão representadas em cada um. Cada grupo receberá uma palavra que supostamente os alunos conhecem (Por exemplo: mãe, criança, por favor, obrigada, casa, etc.) e que será escrita por eles em cartões. Os cartões deverão ser reunidos, misturados e distribuídos. Agora cada quarteto deverá descobrir os falantes que têm mais informações sobre as línguas.

Mas certamente deve-se investigar qual é a língua que consta no cartão recebido: de qual língua vem a expressão "ekmek" 22 e o que isso significa? Caso haja crianças cujo turco é a língua materna, então tal expressão pode ser apresentada na atividade. Os cartões também podem ser preparados pelo próprio professor com a ajuda de um dicionário de viagem e distribuídos às respectivas crianças. Assim, para os outros, a experiência de desvendamento ${ }^{23}$ para a questão "que língua é essa" seja talvez maior ainda.

\footnotetext{
${ }^{21}$ No contexto da União Europeia as embalagens dos produtos apresentam, normalmente, os rótulos nas línguas oficiais do bloco. Os cidadãos da União Europeia têm o direito de se dirigir às instituições oficiais em qualquer uma das 24 línguas e de serem respondidos. Além disso, quaisquer projetos de lei devem ser obrigatoriamente traduzidos para todos os idiomas oficiais no prazo de no máximo oito semanas.

22 "Ekmek" significa pão em português.

${ }^{23} \mathrm{O}$ termo usado por Krumm no texto original é "Aha-Erlebnis", um conceito postulado pelo psicólogo Karl Bühler e que consiste na experiência de desvendamento de um problema após um processo de investigação.
} 
6. A corporeidade da experiência linguística deve ser levada em consideração durante o trabalho com os retratos linguísticos, assim como durante o aprendizado de uma língua estrangeira. As crianças "se incorporam" enquanto fazem seus retratos linguísticos e estabelecem uma relação indivisível entre seu corpo e as línguas que são faladas por elas.

\section{Cristina, 14 anos}

Alemão: na cabeça, porque essa é a língua em que eu penso.

Espanhol: na cabeça, porque é a minha segunda língua materna.

Inglês: no pescoço e nos pés; não falo com fluência. Eu não consigo me expressar frequentemente como eu quero - "pé frio", "sapo na garganta”. Italiano: no coração, porque eu gostaria de falar de qualquer jeito e eu amo o país.

Que Valon tenha dividido seu corpo de cima até embaixo em duas metades (azul alemão; vermelho - albanês), que quase metade de todos os retratos linguísticos apresentam o vermelho como a cor da língua materna ou situem a língua materna onde o coração se localiza, que as línguas situadas na cabeça, nas mãos e nas pernas costumam exercer uma função prática muito importante. Essas questões devem ser discutidas em sala de aula por meio de exercícios de movimentação e gesticulação. Por exemplo:

-Para uma canção em inglês ou um texto, todos que coloriram o inglês na cabeça, devem balançá-la; todos que coloriram nas mãos, devem acenar; todos que coloriram nas pernas e pés devem dançar, e assim por diante.

-Exercícios individuais também são concebíveis. Cristiana, a criança que coloriu o inglês no pescoço, pode coaxar; aqueles, que coloriram o italiano na barriga, porque gostam de comer comida italiana, podem tentar pronunciar corretamente uma palavra como Spaghetti. Aqueles, que coloriram o alemão em preto por considerarem uma língua difícil, podem tentar encontrar palavras em alemão que sejam fáceis de pronunciar, como braço ou perna, ou, por exemplo, palavras estrangeiras, como àquelas que vêm das suas respectivas línguas maternas e que, por essa razão, não são tão 
difíceis. Essas formas de incorporação ajudam a superar inibições e medos linguísticos.

7. Um retrato linguístico da classe ou da escola deve deixar claro que não só indivíduos, mas toda a classe/escola/cidade tem uma grande diversidade linguística. Em primeiro lugar, um barômetro linguístico de classe poderia ser feito para mostrar quantos idiomas diferentes são falados no grupo com cada palavra em uma nova língua e com cada criança trazendo novos idiomas para a sala de aula, o nível do barômetro aumentará (o que torna mais fácil para as novas crianças se integrarem, pois podem contribuir diretamente para o aumento do barômetro). Talvez pode ser que esse barômetro da classe se transforme em um barômetro da escola. Em longo prazo poderá ser distinguido por meio das cores quantas línguas podemos falar, em quantas línguas podemos escrever, quantas línguas podemos constatar quando questionamos nossos amigos, pais, etc. Por essa razão, Schader (2000: 109) sugere a confecção de uma tabela de línguas na sala (ou na escola) que será gradualmente expandida.

Durante todas essas atividades é importante manter em foco os objetivos gerais: -As crianças devem ser conscientizadas sobre a sua diversidade linguística isso também se aplica aos filhos de migrantes que podem cometer mais erros gramaticais em alemão mas também contribuem para a riqueza linguística do grupo.

-O objetivo é desenvolver a conscientização linguística que conduz as crianças a entenderem o aprendizado da língua e o multilinguismo como um elemento natural em seu mundo. Também torna mais fácil estimulá-los a aprender outros idiomas.

-As crianças devem ter a experiência de poder se comunicar com pessoas diferentes, que falam outras línguas, que possuem outras aparências, de modo que elas possam compreender que é possível aprender algo com essa experiência.

Para os professores, o reconhecimento do multilinguismo da sala de aula poderia ser uma ocasião para confiar mais nas crianças, dar-lhes mais a palavra e talvez até sentir vontade de descobrir novas línguas. Ao mesmo tempo, os retratos de linguagem e seus comentários pelos alunos fornecem acesso às teorias subjetivas de 
jovens aprendizes de línguas de modo que é possível considerar com mais consistência emoção e cognição, conforme House (1998) já afirma:

A maior complexidade da rede cognitiva existente (deveria necessitar) necessita de uma maior conscientização dos contrastes e semelhanças estruturais, linguísticas e culturais [...], i. e. a consciência metalinguística e metapragmática deveria ser promovida de uma maneira especial, de modo que o que um aluno já sabe possa ser totalmente utilizado. (HOUSE, 1998: 95) 


\section{Formulários}

\section{Formulário 1}

1. Você autoriza o uso dessa atividade para fins de pesquisa?

$\operatorname{Sim}(\quad$ ) Não ( )

Assinatura:

Data:

Local:

Formulário 2

1. Fala/conhece mais de uma língua?

$\operatorname{Sim}(\quad) \quad$ Não ( )

2. Em caso afirmativo, especifique:

Formulário 3

1. Você deve colorir essa imagem mostrando as línguas que fala ou que conhece.

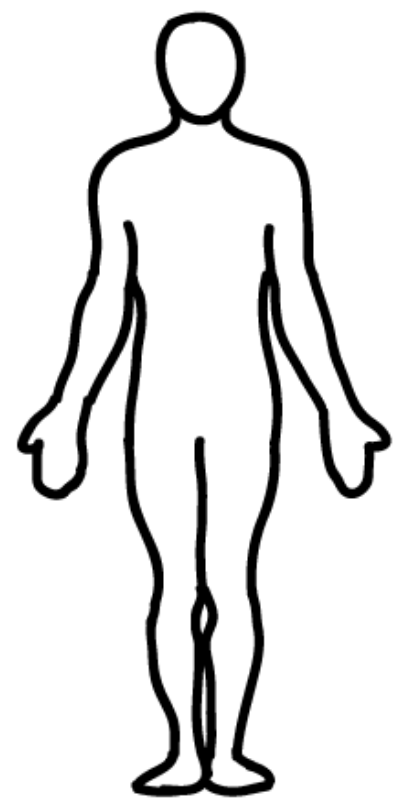

Formulário 4

1. Porque você coloriu o retrato assim? Poderia dar maiores informações? 


\section{Referências bibliográficas}

ACNUR. Refúgio no Brasil. Brasília: ACNUR, 2017.

Protegendo Refugiados no Mundo. Brasília: ACNUR, 2018.

ADUS. Relatório Anual ADUS. São Paulo: Instituto Adus de Reintegração do Refugiado, 2016.

ARAÚJO, W. O desafio de ser refugiado. In: MILESI, R. (Org.). Refugiados realidades e perspectivas. São Paulo: CSEM, IMDH e Edições Loyola, p. 33-44, 2003.

ARENDT, H. Origens do Totalitarismo. São Paulo: Companhia das Letras, 2004.

BARBOSA, L. M. A.; SÃO BERNARDO, M. A. Português para refugiados: especificidades para acolhimento e inserção. In: SIMÕES, D. M. P.; FIGUEIREDO, F. J. Q. (Orgs.). Metodologias em/de linguística aplicada para ensino e aprendizagem de línguas. Campinas: Pontes, p. 269-278, 2014.

BARRENCHE, J. Refugiados Colombianos no Brasil - interpretações das suas travessias internas. Tese de mestrado. Campinas: UNICAMP, 2007.

BERRY, J. W. Immigration, Acculturation and Adaptation. In: Applied Psychology an international review. Nova Jersey: Wiley, vol. 46, p. 5-68, 1997.

BITTENS, C.; JENNINGS-WINTERLE, F. O começo do começo: a promoção do vínculo afetivo e o desenvolvimento emocional e cognitivo pela língua de herança. In: JENNINGS-WINTERLE, F.; LiMA-HERnANDE, M. C. Português como língua de herança: a filosofia do começo, meio e fim. Nova York: BEM, p. 58-80, 2015.

BORGES, L. M. Migração involuntária como fator de risco à saúde mental. In: Revista Internacional de Mobilidade Humana. Brasília: CSEM, n. 40, p. 151-162, 2013. 
BOSI, E. Cultura e desenraizamento. In: BOSI, A. (Org.). Cultura brasileira - temas e situações. São Paulo: Ática, p. 16-41, 1987.

BUlfinCH, T. O Livro de Ouro da Mitologia. Trad. David Jardim Júnior. Rio de Janeiro: Ediouro, 2002.

CHULATA, K. A. Manutenção de línguas de herança: para uma didática da memória linguística. In: Revista Lincool. Nova York: Brasil em Mente, n.1, p. 1-15, 2016.

COELHO, M. L. Imagens das Línguas de alunos do 6. ${ }^{\circ}$ ano: um estudo em Aveiro. Relatório de Estágio. Aveiro: Universidade de Aveiro, 2015.

DANTAS, S.; UENO, L.; LEIFERT, G.; SUGUIURA, M. Identidade, migração e suas dimensões psicossociais. In: Revista Internacional de Mobilidade Humana. Brasília: CSEM, n. 34, p. 45-60, 2010.

DAMÁSIO, A. R. E o cérebro criou o homem. Trad. Laura Teixeira Mota. São Paulo: Companhia das Letras, 2009.

FIORAVANTI, C. As raízes da resistência. In: Revista FAPESP. São Paulo: Fundação de Amparo à Pesquisa do Estado de São Paulo, n. 236, p. 16-23, 2015.

FREITAS, L. G. Discurso e identidade em narrativas de imigrantes. Tese de Doutorado. Brasília: Universidade de Brasília, 2008.

GONÇALVES FILHO, J. M. Humilhação social - um problema político em psicologia. In: Revista Psicologia USP. São Paulo: Universidade de São Paulo, v. 9, n. 2, p. 11-67, 1998.

HALL, S. A identidade cultural na pós-modernidade. Trad. Tomaz Tadeu da Silva e Guacira Lopes Louro. Rio de Janeiro: Lamparina, 2014. 
JUNG, C. G. Os arquétipos e o inconsciente coletivo. Trad. Dora Mariana Ferreira da Silva. Petrópolis: Vozes, 2002.

KRISTEVA, J. Estrangeiros para nós mesmos. São Paulo: Rocco, 1994.

KRUMM, H. J. Mehrsprachigkeit in Sprachenporträts und Sprachenbiographien von Migrantinnen und Migranten. In: Der Arbeitskreis Deutsch als Fremdsprache/Zweitsprache Rundbrief. Jona: AkDaf, vol. 61, p. 16-24, 2010.

Mein Bauch ist italienisch. In: BAUMGARTEN, N.; BÖTTGER, C.; MOTZ, M.; PROBST, J. (Orgs.). Übersetzen, interkullturelle Kommunikation, Spracherwerb und Sprachvermittlung - das Leben mit mehreren Sprachen. Bochum: AKS-Verlag, p.110-114, 2003.

LABOV, W. Padrões sociolinguísticos. São Paulo: Parábola, 2008.

LAMBERT, W. W.; LAMBERT, W. E. Psicologia social. Rio de Janeiro: Zahar, 1967.

LANDABURU, J. Últimos desarrollos de la Linguistica Amerindia em Colombia: el Programa de Base de Datos del Centro Colombiano de Estudios de lenguas aborígenes. In: Revista Liames. Campinas: UNICAMP, v. 1, p. 13-20, 2001.

LIMA-HERNANDES, M. C.; CIOCCHI-SASSI, K. Língua de herança como integradora de identidades. In: JENNINGS-WINTERLE, F.; LIMA-HERNANDE, M. C. Português como língua de herança: a filosofia do começo, meio e fim. Nova York: BEM, p. 104-115, 2015.

LOPES, A. M. D. Da coexistência à convivência com o outro: entre o multiculturalismo e a interculturalidade. In: Revista História Oral. Rio de Janeiro: Associação Brasileira de História Oral, vol. 14, p. 97-122, 2011. 
MANSEN, R.; CAPTAIN, D. El idioma Wayuu (o Guajiro). In: PÉREZ, M. S. G.; MONTES, L. R. (Orgs). Lenguas indígenas de Colombia: uma visión descriptiva. Bogotá: Instituto Caro y Cuervo, p. 795-810, 2000.

MARCOLINI, A. As perspectivas para os refugiados no século XXI. In: MILESI, R. (Org.). Refugiados - realidades e perspectivas. São Paulo: CSEM, IMDH e Edições Loyola, p. 13-20, 2003.

MELO-PFEIFER, S.; SIMÕES, R. Plurilinguismo vivido, plurilinguismo desenhado: estudos sobre a relação dos sujeitos com as línguas. Santarém: Insituto Politécnico de Santarém, 2017.

MENEZES, T. S. Direitos Humanos e Direito Internacional dos refugiados: uma relação de complementaridade. In: Anais dos $3^{\text {o }}$ Encontro Nacional ABRI 2011 Governança Global e Novos Atores. São Paulo: ABRI, p. 12-35, 2011.

MINISTÉRIO DE JUSTIÇA. Migrantes, Apátridas e Refugiados. Brasília: IPEA, 2015

MOREIRA, J.; BAENINGER, R. A integração local de refugiados no Brasil. In: Forced Migration Review. Oxford: University of Oxford, vol. 35, p. 30-31, 2010.

MOREIRA, J. Política Externa, Refugiados e Reassentamento no Brasil: uma análise sobre o período do governo Lula (2003-2010). In: Revista Carta Internacional. São Paulo, ABRI, vol. 10, p. 133-151, 2015.

NASCIMENTO, L. S. A cidadania dos refugiados no Brasil. São Paulo: Verbatim, 2014.

OLIVEIRA JÚNIOR, A. Mitos fundadores. In: Revista Página 22. São Paulo: FGV, p. 42-49, 2016. 
PENNA, M. Relatos de migrantes: questionando as noções de perda da identidade e desenraizamento. In: SIGNORI, I. (Org.). Lingua(gem) e identidade: elementos para uma discussão no campo aplicado. Campinas: Mercado de Letras, p. 89-111, 2001.

PETTER, M. A presença de línguas africanas na América Latina. In: Revista Linguística. Bogotá: ALFAL, p. 78-96, 2011.

PITA, A. C. Direitos Humanos e Direito Internacional de Proteção ao Refugiado. In: GEDIEL, J. A. P.; GODOY, G. G. (Orgs.). Refúgio e Hospitalidade. Brasília: ACNUR, p. 5-16, 2016

REVUZ, C. A língua estrangeira entre o desejo de um outro lugar e o risco do exílio. Trad. Silvane Serrani-Infanti. In: SIGNORI, I. Lingua(gem) e identidade: elementos para uma discussão no campo aplicado. Campinas: Mercado de Letras, p. 213-230, 2001.

RIZZO, R. Cuidado ao ouvir: refúgio e narrativa. In: Caderno de Debates - Refúgio, Migrações e Cidadania. Brasília: IMDH, vol. 6, p. 99-116, 2011.

RODRIGUES NETO, C. F. Reassentamento de refugiados no Brasil. In: MILESI, R. (Org.). Refugiados - realidades e perspectivas. São Paulo: CSEM, IMDH e Edições Loyola, p. 155-171, 2003.

SEALS, C. A. Positive and negative identity practices in heritage language education. In: International Journal of Multilingualism. Oxford: Taylor \& Francis, v. 35, p. 121, 2017.

SEYFERTH, G. Colonização, imigração e a questão racial no Brasil. In: Revista USP. São Paulo: Universidade de São Paulo, n. 53, p. 117-149, 2002.

SILVA, J. A. Curso de Direito Constitucional Positivo. São Paulo: Saraiva, 2009. 
SOARES, M. Áreas linguísticas da América Latina - uma introdução ao tema. In: Revista Liames. Campinas: UNICAMP, v. 1, p. 7-11, 2001.

SPRANDEL, M. A.; MILESI, R. O acolhimento de refugiados no Brasil: histórico, dados e reflexões. In: MILESI, R. (Org.). Refugiados - realidades e perspectivas. São Paulo: CSEM, IMDH e Edições Loyola, p. 113-134, 2003.

TRAUMANN, A. Os colombianos. São Paulo: Contexto, 2018.

VERWEY, A.; ZERBINI, R.; SILVA, A. A percepção brasileira dos refugiados. In: Revista Brasileira de Política Internacional. Brasília: Instituto Brasileiro de Relações Internacionais, vol. 43, p. 183-185, 2000.

WEIL, S. O desenraizamento operário. In: A condição operária e outros estudos sobre a opressão. Rio de Janeiro: Paz e Terra, 1996. 